Nevada

Environmental

Restoration

Project

Streamlined Approach for

Environmental Restoration (SAFER)

Plan for Corrective Action Unit 124:

Storage Tanks

Nevada Test Site, Nevada

Controlled Copy No.:

Revision No.: 0

April 2007

Approved for public release; further dissemination unlimited.

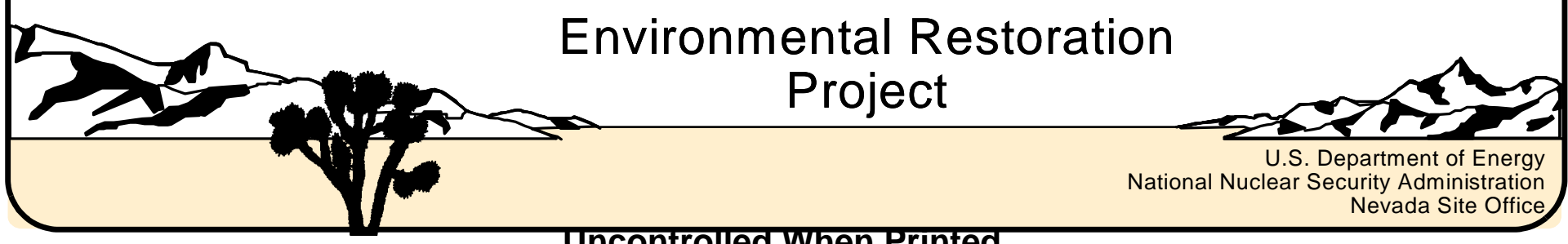


Available for public sale, in paper, from:

U.S. Department of Commerce

National Technical Information Service

5285 Port Royal Road

Springfield, VA 22161

Phone: 800.553.6847

Fax: 703.605.6900

Email: orders@ntis.gov

Online ordering: http://www.ntis.gov/ordering.htm

Available electronically at http://www.osti.gov/bridge

Available for a processing fee to U.S. Department of Energy and its contractors, in paper, from:

\section{U.S. Department of Energy}

Office of Scientific and Technical Information

P.O. Box 62

Oak Ridge, TN 37831-0062

Phone: 865.576.8401

Fax: 865.576.5728

Email: reports@adonis.osti.gov

Reference herein to any specific commercial product, process, or service by trade name, trademark, manufacturer, or otherwise, does not necessarily constitute or imply its endorsement, recommendation, or favoring by the United States Government or any agency thereof or its contractors or subcontractors. 


\title{
STREAMLINED APPROACH FOR ENVIRONMENTAL RESTORATION (SAFER) PLAN FOR CORRECTIVE ACTION UNIT 124: STORAGE TANKS NEVADA TEST SITE, NEVADA
}

\author{
U.S. Department of Energy \\ National Nuclear Security Administration \\ Nevada Site Office \\ Las Vegas, Nevada
}

Controlled Copy No.:

Revision No.: 0

April 2007

Approved for public release; further dissemination unlimited. 
STREAMLINED APPROACH FOR ENVIRONMENTAL RESTORATION (SAFER) PLAN FOR CORRECTIVE ACTION UNIT 124:

STORAGE TANKS

NEVADA TEST SITE, NEVADA

Approved by: /s/ Kevin J. Cabble

Date: 04/04/2007

Kevin J. Cabble

Federal Sub-Project Director

Industrial Sites Sub-Project

Approved by: /s/ John B. Jones

Date: 04/04/2007

John B. Jones

Acting Federal Project Director

Environmental Restoration Project 


\section{Table of Contents}

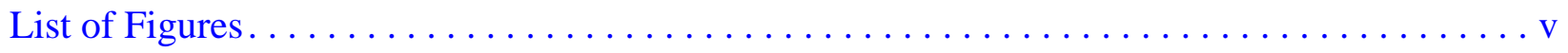

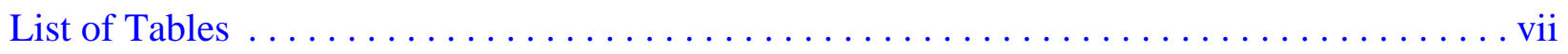

List of Acronyms and Abbreviations $\ldots \ldots \ldots \ldots \ldots \ldots \ldots \ldots \ldots \ldots \ldots \ldots \ldots \ldots \ldots \ldots$

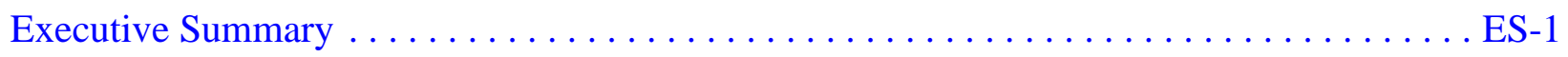

$1.0 \quad$ Introduction. . . . . . . . . . . . . . . . . . . . . .

1.1 SAFER Process Description . . . . . . . . . . . . . . . . . . 3

1.2 Summary of Corrective Actions and Closures $\ldots \ldots \ldots \ldots \ldots \ldots \ldots \ldots$

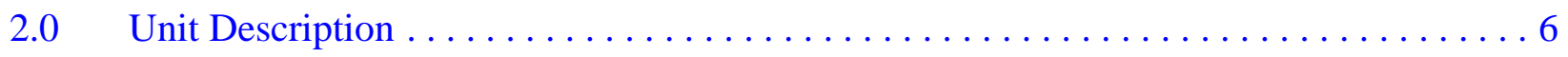

2.1 Corrective Action Site 08-02-01, Underground Storage Tank . . . . . . . . . 6

$2.1 .1 \quad$ History and Process Knowledge . . . . . . . . . . . . . . . 8

2.1.2 Available Characterization Information $\ldots \ldots \ldots \ldots \ldots \ldots \ldots$

2.2 Corrective Action Site 15-02-01, Irrigation Piping . . . . . . . . . . . . 8

2.2.1 History and Process Knowledge . . . . . . . . . . . . . 9

2.2.2 Available Characterization Information . . . . . . . . . . . . . . . . 12

2.3 Corrective Action Site 16-02-03, Underground Storage Tank . . . . . . . . . . 12

2.3.1 History and Process Knowledge . . . . . . . . . . . . . . . . 12

2.3.2 Available Characterization Information . . . . . . . . . . . . . . . 14

2.4 Corrective Action Site 16-02-04, Fuel Oil Piping . . . . . . . . . . . . . . . 16

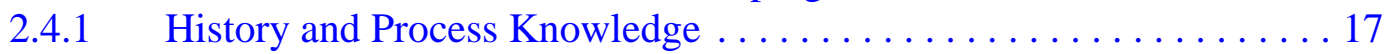

2.4.2 Available Characterization Information . . . . . . . . . . . . . . 17

2.5 Corrective Action Site 16-99-04, Fuel Line (Buried) and UST . . . . . . . . . 17

2.5.1 History and Process Knowledge . . . . . . . . . . . . . . . 18

2.5.2 Available Characterization Information . . . . . . . . . . . . . 19

$3.0 \quad$ Data Quality Objectives . . . . . . . . . . . . . . . . . . . . 21

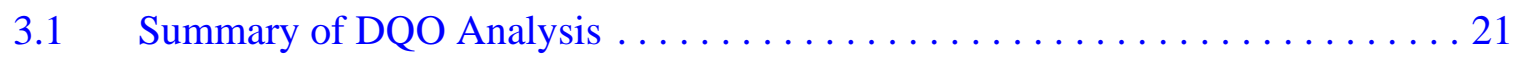

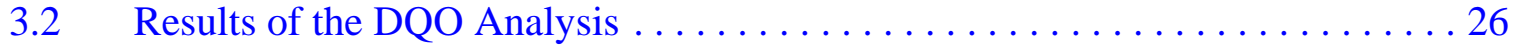

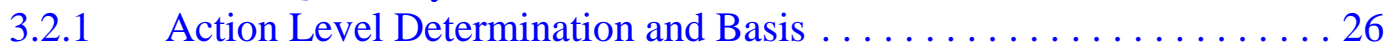

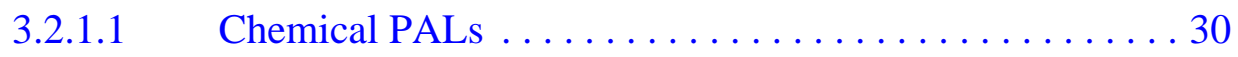

3.2.1.2 Total Petroleum Hydrocarbons PALs . . . . . . . . . 32

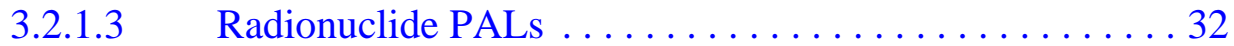

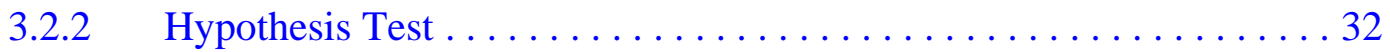

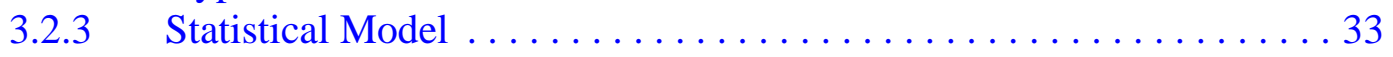

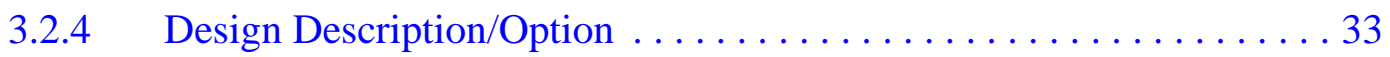

3.2.5 Conceptual Site Model and Drawing. . . . . . . . . . . . . 34

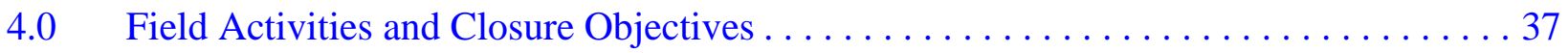




\section{Table of Contents (Continued)}

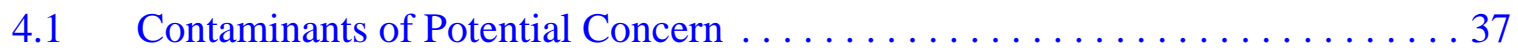

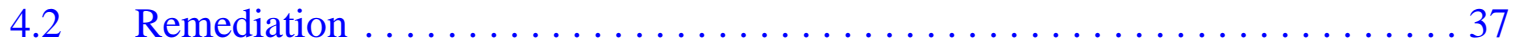

$4.3 \quad$ Verification........................................ 38

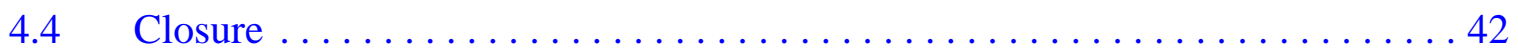

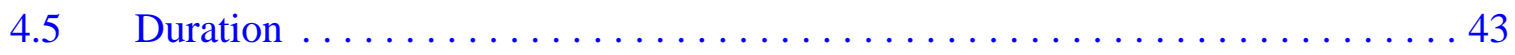

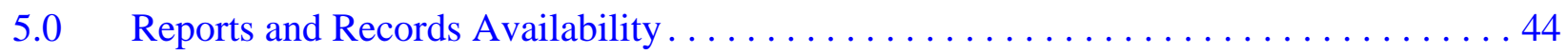

6.0 Investigation/Remediation Waste Management ..................... 45

$6.1 \quad$ Waste Minimization . . . . . . . . . . . . . . . . . . . . . . . . 45

6.2 Potential Waste Streams . . . . . . . . . . . . . . . . . . . . . . 46

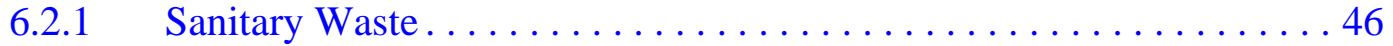

6.2.2 Low-Level Radioactive Waste. ....................... 48

6.2.3 Hazardous Waste . . . . . . . . . . . . . . . . . . . . . . . . . 49

$6.2 .4 \quad$ Hydrocarbon Waste ............................ 49

6.2 .5 Mixed Low-Level Waste . . . . . . . . . . . . . . . . . . . . . . 49

6.2.6 Polychlorinated Biphenyls. . . . . . . . . . . . . . . . . . . . . 50

6.3 Management of Specific Waste Streams . . . . . . . . . . . . . . . 50

6.3.1 Personal Protective Equipment .................... 50

6.3.2 Management of Decontamination Rinsate................. 51

6.3.3 Management of Soil.......................... 52

6.3.4 Management of Debris......................... 52

6.3.5 Field-Screening Waste. .......................... 53

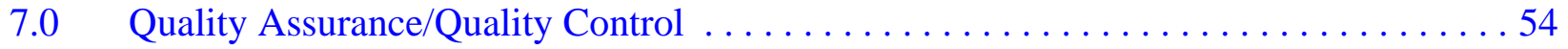

$7.1 \quad$ Sample Collection Activities ................................ 54

7.2 Applicable Laboratory/Analytical Data Quality Indicators . . . . . . . . . . . 55

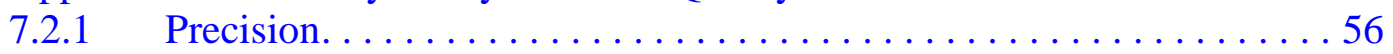

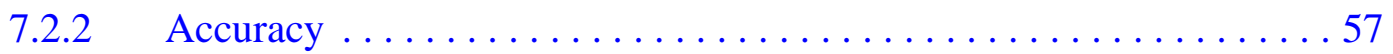

7.2.3 Representativeness.......................... 58

$7.2 .4 \quad$ Comparability ................................ 59

$7.2 .5 \quad$ Completeness.............................. 59

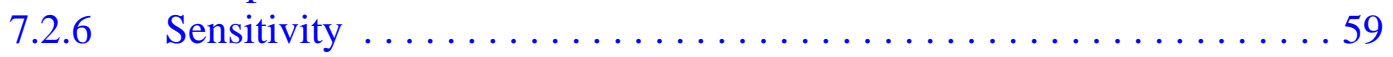

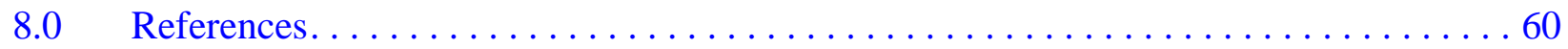

\section{Appendix A - Project Organization}

A.1.0 Project Organization.................................. 


\section{Table of Contents (Continued)}

\section{Appendix B - Data Quality Objectives Process}

B.1.0 Introduction. . . . . . . . . . . . . . . . .

B.2.0 Step 1 - State the Problem. . . . . . . . . . . . . . . .

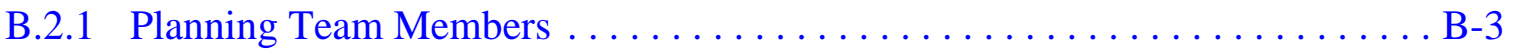

B.2.2 Conceptual Site Model . . . . . . . . . . . . . . . . . . . . . B-3

B.2.2.1 Contaminant Release . . . . . . . . . . . . . . . . . . B-9

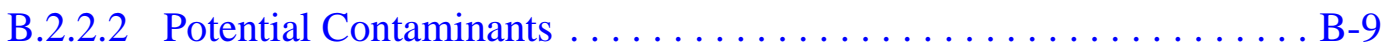

B.2.2.3 Contaminant Characteristics ..................... B-11

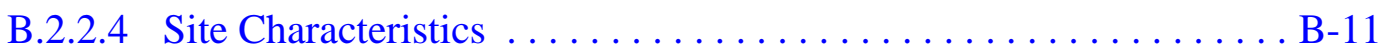

B.2.2.5 Migration Pathways and Transport Mechanisms. . . . . . . . . . . B B-12

B.2.2.6 Exposure Scenarios . . . . . . . . . . . . . . . B-13

B.3.0 Step 2 - Identify the Goal of the Study . . . . . . . . . . . . . . . . B-15

B.3.1 Decision Statements . . . . . . . . . . . . . . . . . . . . . . . B-15

B.3.2 Alternative Actions to the Decisions . . . . . . . . . . . . . . B-17

B.3.2.1 Alternative Actions to Decision I . . . . . . . . . . . . . . . B-17

B.3.2.2 Alternative Actions to Decision II . . . . . . . . . . . . . B-17

B.4.0 Step 3 - Identify Information Inputs . . . . . . . . . . . . . . . . B-18

B.4.1 Information Needs . . . . . . . . . . . . . . . . . . . B-18

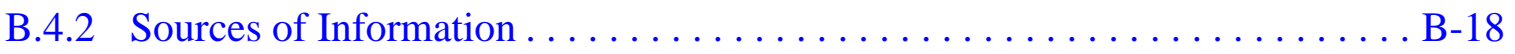

B.4.2.1 Sample Locations. . . . . . . . . . . . . . . . . . . B-19

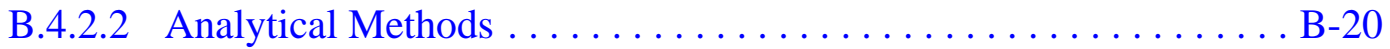

B.5.0 Step 4 - Define the Boundaries of the Study $\ldots \ldots \ldots \ldots \ldots \ldots \ldots \ldots \ldots \ldots$. . . . . . .

B.5.1 Target Populations of Interest. . . . . . . . . . . . . . . . . . B-21

B.5.2 Spatial Boundaries . . . . . . . . . . . . . . . . . . . . . . . . . . . .

B.5.3 Practical Constraints . . . . . . . . . . . . . . . . . $\ldots \ldots \ldots$

B.5.4 Define the Sampling Units . . . . . . . . . . . . . . . . .

B.6.0 Step 5 - Develop the Analytic Approach . . . . . . . . . . . . . . . . . B-24

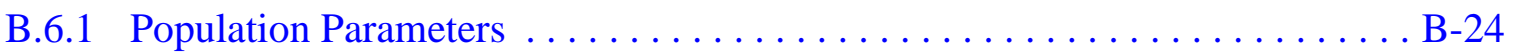

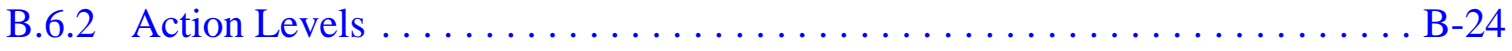

B.6.2.1 Chemical PALs . . . . . . . . . . . . . . . . . . B-25

B.6.2.2 Total Petroleum Hydrocarbons PALs . . . . . . . . . . . . . B-26

B.6.2.3 Radionuclide PALs . . . . . . . . . . . . . . . . . . . B-26

B.6.3 Decision Rules . . . . . . . . . . . . . . . . . . B-26

B.7.0 Step 6 - Specify Performance or Acceptance Criteria . . . . . . . . . . . . . . . . B-28

B.7.1 Decision Hypotheses. . . . . . . . . . . . . . . . . . B-28 


\section{Table of Contents (Continued)}

B.7.2 False Negative Decision Error $\ldots \ldots \ldots \ldots \ldots \ldots \ldots \ldots \ldots \ldots \ldots \ldots \ldots \ldots$

B.7.3 False Positive Decision Error . . . . . . . . . . . . . . . . . . . . B-30

B.8.0 Step 7 - Develop the Plan for Obtaining Data $\ldots \ldots \ldots \ldots \ldots \ldots \ldots \ldots \ldots$ B-32

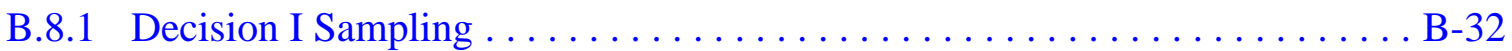

B.8.2 Decision II Sampling $\ldots \ldots \ldots \ldots \ldots \ldots \ldots \ldots \ldots \ldots \ldots \ldots \ldots \ldots \ldots \ldots \ldots \ldots$

B.8.3 Corrective Action Site 08-02-01, Underground Storage Tank............ B-33

B.8.4 Corrective Action Site 15-02-01, Irrigation Piping . . . . . . . . . . . B-36

B.8.5 Corrective Action Site 16-02-03, Underground Storage Tank. . . . . . . . . B-39

B.8.6 Corrective Action Site 16-02-04, Fuel Oil Piping . . . . . . . . . . . B-42

B.8.7 Corrective Action Site 16-99-04, Fuel Line (Buried) and UST . . . . . . . . . . B-44

B.9.0 References. . . . . . . . . . . . . . . . . . . . . . . . . . . . . . . . B-47

Appendix C - Nevada Division of Environmental Protection Comments 


\section{List of Figures}

Number

Title

Page

1-1 Nevada Test Site Map with CAU 124 CAS Locations . . . . . . . . . . . . . . 2

1-2 CAU 124 Closure Decision Process $\ldots \ldots \ldots \ldots \ldots \ldots \ldots \ldots \ldots \ldots$

2-1 CAS 08-02-01 Location, Surrounding Roads, and Physical Features. . . . . . . 7

2-2 Oblique Photo Showing CAS 15-02-01 Roads, Buildings, CAS

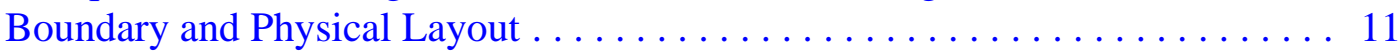

2-3 Area 16 CASs 16-02-03, 16-02-04, and 16-99-04 Surrounding Roads and Other Physical Features . . . . . . . . . . . . . . . . 13

2-4 CAS 16-02-03, Site Conditions and Physical Layout . . . . . . . . . . . 14

2-5 CAS 16-02-03, Science Applications International Corporation Geophysical Survey. ......................... 15

2-6 CAS 16-02-04, Site Conditions and Physical Layout . . . . . . . . . . . 16

2-7 CAS 16-99-04, Site Conditions and Physical Layout . . . . . . . . . . 18

2-8 CAS 16-99-04, Science Applications International Corporation Geophysical Survey. .......................... 20

3-1 Risk-Based Corrective Action Decision Process . . . . . . . . . . . 31

3-2 Conceptual Site Model for CAU $124 \ldots \ldots \ldots \ldots \ldots \ldots \ldots \ldots \ldots$

3-3 Conceptual Site Model Diagram for CAU $124 \ldots \ldots \ldots \ldots \ldots \ldots \ldots$

B.2-1 Conceptual Site Model for CAU 124 CASs . . . . . . . . . . . . . . . B-5

B.2-2 Conceptual Site Model Diagram for CAU 124 CASs. . . . . . . . . . . . . . . . . B-8

B.3-1 SAFER Closure Decision Process for CAU 124. . . . . . . . . . . . . B-16

B.8-1 Current Site Conditions at CAS $08-02-01 \ldots \ldots \ldots \ldots \ldots \ldots \ldots \ldots \ldots$. . . . . . . .

B.8-2 Proposed Sample Locations at CAS $08-02-01 \ldots \ldots \ldots \ldots \ldots \ldots$. . . . . . . . .

B.8-3 Current Site Conditions at CAS $15-02-01 \ldots \ldots \ldots \ldots \ldots \ldots \ldots \ldots \ldots$. . . . . . . .

B.8-4 Proposed Sample Locations at CAS $15-02-01 \ldots \ldots \ldots \ldots \ldots \ldots \ldots$. . . . . . . . .

B.8-5 Current Site Conditions at CAS $16-02-03 . \ldots \ldots \ldots \ldots \ldots \ldots \ldots \ldots \ldots \ldots$

B.8-6 Proposed Sample Locations at CAS $16-02-03 \ldots \ldots \ldots \ldots \ldots \ldots \ldots \ldots$. . . . . . . . . 


\section{List of Figures (Continued)}

Number

Title

Page

B.8-7 Current Site Conditions at CAS $16-02-04 \ldots \ldots \ldots \ldots \ldots \ldots \ldots \ldots$. . . . . . . . . .

B.8-8 Proposed Sample Locations for CAS $16-02-04 \ldots \ldots \ldots \ldots \ldots \ldots \ldots \ldots$. . . . . . .

B.8-9 Current Site Conditions at CAS 16-99-04 .................. B-44

B.8-10 Proposed Sample Locations at CAS $16-99-04 \ldots \ldots \ldots \ldots \ldots \ldots \ldots$. . . . . . . . . 


\section{List of Tables}

Number

Title

Page

ES.1-1 Summary of Conceptual Site Model Assumptions and Expected Closures .... ES-3

3-1 Analytical Program ${ }^{\mathrm{a}}$ (Includes Waste Characterization Analyses) . . . . . . . . 22

3-2 Analytes Reported by Analytical Methods .................. 24

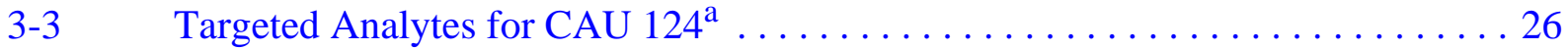

3-4 Analytical Requirements for Radionuclides for CAU $124 \ldots \ldots \ldots \ldots$. . . . . 27

3-5 Analytical Requirements for Chemical COPCs for CAU $124 \ldots \ldots$. . . . . . 28

4-1 Sampling Approach for CAU 124 CASs. . . . . . . . . . . . . . 40

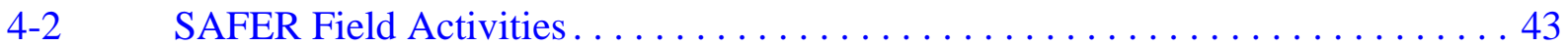

6-1 Waste Management Regulations and Requirements . . . . . . . . . . . 47

7-1 Laboratory and Analytical Performance Criteria for CAU 124 Data

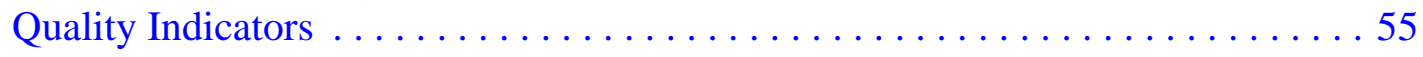

B.2-1 Conceptual Site Model Description of Elements for Each CAU 124 CAS. . . . . B-6

B.2-2 Analytical Program ${ }^{\mathrm{a}}$ (Includes Waste Characterization Analyses) . . . . . . . . B-10

B.2-3 Targeted Contaminants for CAU $124^{\mathrm{a}} \ldots \ldots \ldots \ldots \ldots \ldots \ldots \ldots \ldots \ldots \ldots \ldots$

B.2-4 Land-Use and Exposure Scenarios . . . . . . . . . . . . . . B-14

B.5-1 Spatial Boundaries of CAU 124 CASs $\ldots \ldots \ldots \ldots \ldots \ldots \ldots \ldots \ldots \ldots \ldots \ldots \ldots \ldots$

B.5-2 Practical Constraints for the CAU 124 Field Investigation . . . . . . . . . . . . B-22 


\section{List of Acronyms and Abbreviations}

AST

bgs

CAI

CAS

CAU

CFR

COC

COPC

CR

CSM

DOE

DOT

DQI

DQO

DRO

EPA

FAL

FFACO

FSR

$\mathrm{ft}$

$\mathrm{ft}^{2}$

gal

GRO

HWAA

I

IDW
Aboveground storage tank

Below ground surface

Corrective Action Investigation

Corrective Action Site

Corrective Action Unit

Code of Federal Regulations

Contaminant of concern

Contaminant of potential concern

Closure Report

Conceptual site model

U.S. Department of Energy

U.S. Department of Transportation

Data quality indicator

Data quality objective

Diesel-range organics

U.S. Environmental Protection Agency

Final action level

Federal Facility Agreement and Consent Order

Field-screening result

Foot

Square foot

Gallon

Gasoline-range organics

Hazardous waste accumulation area

Iodine

Investigation-derived waste 


\section{List of Acronyms and Abbreviations (Continued)}

\begin{tabular}{|c|c|}
\hline in. & Inch \\
\hline in./yr & Inches per year \\
\hline LCS & Laboratory control sample \\
\hline LLNL & Lawrence Livermore National Laboratory \\
\hline MDC & Minimum detectable concentration \\
\hline $\mathrm{mg} / \mathrm{kg}$ & Milligrams per kilogram \\
\hline $\mathrm{mg} / \mathrm{L}$ & Milligrams per liter \\
\hline $\mathrm{mi}$ & Mile \\
\hline $\mathrm{mrem} / \mathrm{yr}$ & Millirem per year \\
\hline MS & Matrix spike \\
\hline N/A & Not applicable \\
\hline NAC & Nevada Administrative Code \\
\hline NCRP & National Council on Radiation Protection and Measurement \\
\hline ND & Normalized difference \\
\hline NDEP & Nevada Division of Environmental Protection \\
\hline NNSA/NSO & $\begin{array}{l}\text { U.S. Department of Energy, National Nuclear Security Administration } \\
\text { Nevada Site Office }\end{array}$ \\
\hline NRS & Nevada Revised Statutes \\
\hline NTS & Nevada Test Site \\
\hline NTSWAC & Nevada Test Site Waste Acceptance Criteria \\
\hline PAL & Preliminary action level \\
\hline PCB & Polychlorinated biphenyl \\
\hline $\mathrm{pCi} / \mathrm{g}$ & Picocuries per gram \\
\hline $\mathrm{pCi} / \mathrm{L}$ & Picocuries per liter \\
\hline POC & Performance Objective for the Certification of Nonradioactive Hazardous Waste \\
\hline PPE & Personal protective equipment \\
\hline ppm & Parts per million \\
\hline
\end{tabular}




\section{List of Acronyms and Abbreviations (Continued)}

$\begin{array}{ll}\text { PRG } & \text { Preliminary remediation goal } \\ \text { PVC } & \text { Polyvinyl chloride } \\ \text { QA } & \text { Quality assurance } \\ \text { QAPP } & \text { Quality Assurance Project Plan } \\ \text { QC } & \text { Quality control } \\ \text { RBCA } & \text { Risk-based corrective action } \\ \text { RCRA } & \text { Resource Conservation and Recovery Act } \\ \text { RL } & \text { Reporting limit } \\ \text { RPD } & \text { Relative percent difference } \\ \text { RMA } & \text { Radioactive Materials Area } \\ \text { SAFER } & \text { Streamlined Approach for Environmental Restoration } \\ \text { SDWS } & \text { Safe Drinking Water Standards } \\ \text { SS } & \text { Site Supervisor } \\ \text { SSTL } & \text { Site-specific target level } \\ \text { SVOC } & \text { Semivolatile organic compound } \\ \text { TPH } & \text { Total petroleum hydrocarbons } \\ \text { TSCA } & \text { Toxic Substances Control Act } \\ \text { UCL } & \text { Upper confidence limit } \\ \text { UGTA } & \text { Underground Test Area } \\ \text { USPHS } & \text { Underground storage tank } \\ \text { W } & \text { Tumple } \\ \text { VSTanic compound }\end{array}$




\section{Executive Summary}

This Streamlined Approach for Environmental Restoration (SAFER) Plan addresses closure for Corrective Action Unit (CAU) 124, Areas 8, 15, and 16 Storage Tanks, identified in the Federal Facility Agreement and Consent Order. Corrective Action Unit 124 consists of five Corrective Action Sites (CASs) located in Areas 8, 15, and 16 of the Nevada Test Site as follows:

- 08-02-01, Underground Storage Tank

- 15-02-01, Irrigation Piping

- 16-02-03, Underground Storage Tank

- 16-02-04, Fuel Oil Piping

- 16-99-04, Fuel Line (Buried) and UST

This plan provides the methodology of field activities necessary to gather information to close each CAS. There is sufficient information and process knowledge from historical documentation and investigations of similar sites regarding the expected nature and extent of potential contaminants to recommend closure of CAU 124 using the SAFER process.

The data quality objective process developed for this CAU identified the following expected closure options: (1) investigation and confirmation that no contamination exists above the preliminary action levels supporting a no further action declaration, or (2) characterization of the nature and extent of contamination leading to closure in place with use restrictions. The expected closure options were selected based on available information including contaminants of potential concern (COPCs), future land use, and assumed risks. A decision flow process was developed to outline the collection of data necessary to achieve closure. There are two decisions that need to be answered for closure. Decision I is to determine if COPCs are present in concentrations exceeding the final action levels (FALs). If COPCs are found to be present above FALs, Decision II activities will be used to determine the extent of contamination and generate all other information necessary to complete site closure.

The following summarizes the types of activities that will support the closure of CAU 124:

- Perform site preparation activities (e.g., build hazardous waste accumulation area). 
- Collect environmental samples from designated target populations (i.e., underground storage tanks [USTs]) to confirm or disprove the presence of contaminants of concern (COCs) (i.e., nature of contamination), as necessary, to supplement existing information.

- If COCs exist, collect environmental samples from designated target populations (e.g., clean soil adjacent to contaminated soil) and submit for laboratory analyses to define the extent of COC contamination.

- Establish no further action as the corrective action if contaminants are not detected above FALs.

- If a COC is present at a CAS, and removal is not feasible, establish closure in place as the corrective action and implement the appropriate use restrictions.

- Confirm the preferred closure option is sufficient to protect human health and the environment.

- Close USTs in accordance with requirements and perform best management practices (e.g., sealing associated piping).

- Document all closure activities for CAU 124 in a Closure Report.

Historical information and process knowledge identified sources of potential contamination for the USTs. See Table ES.1-1 for a summary of the conceptual site model assumptions and expected closures.

Under the Federal Facility Agreement and Consent Order, the SAFER Plan will be submitted to the Nevada Division of Environmental Protection (NDEP) for approval. Field work will be conducted following approval of the plan. Upon completion of field activities, a Closure Report will be prepared and submitted to NDEP for review and approval. 
Table ES.1-1

Summary of Conceptual Site Model Assumptions and Expected Closures

(Page 1 of 2)

\begin{tabular}{|c|c|c|c|}
\hline $\begin{array}{l}\text { Corrective Action } \\
\text { Site }\end{array}$ & $\begin{array}{c}\text { Potential Release of } \\
\text { COCs }\end{array}$ & $\begin{array}{c}\text { Conceptual Site Model } \\
\text { Assumptions }^{a}\end{array}$ & $\begin{array}{l}\text { Expected } \\
\text { Closure }^{b}\end{array}$ \\
\hline 08-02-01 & $\begin{array}{l}\text { COPCs migrating from } \\
\text { observed stained soil are } \\
\text { expected to be contiguous } \\
\text { to the release points and } \\
\text { concentrations to decrease } \\
\text { with distance and depth } \\
\text { from the source. }\end{array}$ & $\begin{array}{l}\text { Limited migration in the surface and } \\
\text { shallow subsurface at the location of } \\
\text { the UST. } \\
\text { Vertical migration in the subsurface } \\
\text { soil below } 20 \mathrm{ft} \text { bgs is limited. Liquid } \\
\text { released from former UST over time } \\
\text { may also have provided a hydraulic } \\
\text { driver for vertical migration of COPCs. }\end{array}$ & No Further Action \\
\hline $15-02-01$ & $\begin{array}{l}\text { Primary source for potential } \\
\text { radiological contamination } \\
\text { is a release associated with } \\
\text { direct spray of iodine-131 } \\
\text { to experimental plots. } \\
\text { Other COPCs migrating } \\
\text { from observed stained soils } \\
\text { are expected to be } \\
\text { contiguous to the release } \\
\text { points and concentrations } \\
\text { to decrease with distance } \\
\text { and depth. } \\
\text { The locations of a release } \\
\text { are expected to be limited } \\
\text { to the CAS boundary. }\end{array}$ & $\begin{array}{l}\text { Limited lateral migration in the surface } \\
\text { soil and minimal vertical migration in } \\
\text { the shallow subsurface soil. } \\
\text { Based on results from previous } \\
\text { investigations, no COCs are } \\
\text { anticipated. Note: verification samples } \\
\text { will be collected and analyzed for a } \\
\text { limited suite of analytes to confirm the } \\
\text { absence of coCs. }\end{array}$ & $\begin{array}{l}\text { No further action } \\
\text { with a contingency } \\
\text { for closure in place } \\
\text { with use restriction }\end{array}$ \\
\hline $16-02-03$ & $\begin{array}{l}\text { COPCs migrating from } \\
\text { observed stained soil are } \\
\text { expected to be contiguous } \\
\text { to the release points and } \\
\text { concentrations to decrease } \\
\text { with distance and depth } \\
\text { from the source. }\end{array}$ & $\begin{array}{l}\text { Limited lateral migration in the surface } \\
\text { and shallow subsurface at the UST } \\
\text { location. } \\
\text { Liquid released from UST over time } \\
\text { may have provided a hydraulic driver } \\
\text { for vertical migration of COPCs. } \\
\text { Vertical migration in the subsurface } \\
\text { soil below } 20 \mathrm{ft} \text { bgs is limited to the } \\
\text { location of the UST. }\end{array}$ & No Further Action \\
\hline
\end{tabular}


Table ES.1-1

Summary of Conceptual Site Model Assumptions and Expected Closures

(Page 2 of 2)

\begin{tabular}{|c|c|c|c|}
\hline $\begin{array}{l}\text { Corrective Action } \\
\text { Site }\end{array}$ & $\begin{array}{l}\text { Potential Release of } \\
\text { COCs }\end{array}$ & $\begin{array}{c}\text { Conceptual Site Model } \\
\text { Assumptions }^{\mathrm{a}}\end{array}$ & $\begin{array}{l}\text { Expected } \\
\text { Closure }^{\text {b }}\end{array}$ \\
\hline $16-02-04$ & \multirow{2}{*}{$\begin{array}{l}\text { COPCs migrating from } \\
\text { observed stained soil are } \\
\text { expected to be contiguous } \\
\text { to the release points and } \\
\text { concentrations to decrease } \\
\text { with distance and depth } \\
\text { from the source. }\end{array}$} & $\begin{array}{l}\text { Limited lateral migration in the surface } \\
\text { and shallow subsurface at the UST } \\
\text { location. } \\
\text { Liquid released from former AST may } \\
\text { have provided a hydraulic driver for } \\
\text { lateral and vertical migration of } \\
\text { COPCs. Vertical migration in the } \\
\text { subsurface soil below } 20 \mathrm{ft} \text { bgs is } \\
\text { limited. }\end{array}$ & No Further Action \\
\hline $16-99-04$ & & $\begin{array}{l}\text { Limited lateral migration in the surface } \\
\text { and shallow subsurface soil from the } \\
\text { fuel line. } \\
\text { Liquid released from UST over time } \\
\text { may have provided a hydraulic driver } \\
\text { for vertical migration of COPCs. } \\
\text { Vertical migration in the subsurface } \\
\text { soil below } 20 \mathrm{ft} \text { bgs is limited to the } \\
\text { location of the UST. }\end{array}$ & No Further Action \\
\hline
\end{tabular}

aSampling intervals for this investigation are designated as follows: Surface is 0 to $0.5 \mathrm{ft} \mathrm{bgs,} \mathrm{shallow} \mathrm{subsurface} \mathrm{is} 0.5$ to $5 \mathrm{ft}$ bgs, and subsurface is greater than $5 \mathrm{ft}$ bgs.

${ }^{b}$ Expected closure alternative for all CASs is no further action; however, if data are insufficient, clean closure and closure in place will be evaluated.

AST $=$ Aboveground storage tank

bgs = Below ground surface

$\mathrm{COC}=$ Contaminant of concern

$\mathrm{COPC}=$ Contaminant of potential concern

$\mathrm{ft}=$ Foot

UST = Underground storage tank 


\subsection{Introduction}

This Streamlined Approach for Environmental Restoration (SAFER) Plan addresses the actions necessary for the closure of Corrective Action Unit (CAU) 124, Storage Tanks, Nevada Test Site (NTS), Nevada. It has been developed in accordance with the Federal Facility Agreement and Consent Order (FFACO, 1996) that was agreed to by the State of Nevada, the U.S. Department of Energy (DOE), and the U.S. Department of Defense.

A SAFER Plan may be performed when the following criteria are met:

- Conceptual corrective actions are clearly identified (although some degree of investigation may be necessary to select a specific corrective action before completion of the corrective action investigation [CAI]).

- Uncertainty of the nature, extent, and corrective action must be limited to an acceptable level of risk.

- The SAFER Plan includes decision points and criteria for making data quality objective (DQO) decisions.

The purpose of the investigation will be to document and verify the adequacy of existing information; affirm the decision for either clean closure, closure in place, or no further action; and provide sufficient data to implement the corrective action. The actual corrective action selected will be based on characterization activities implemented under this SAFER Plan. This SAFER Plan identifies decision points developed in cooperation with the Nevada Department of Environmental Protection (NDEP), where the National Nuclear Security Administration Nevada Site Office (NNSA/NSO) will reach consensus with the NDEP before beginning the next phase of work.

Corrective Action Unit 124 is located in Areas 8, 15, and 16 of the NTS, which is approximately 65 miles (mi) northwest of Las Vegas, Nevada (Figure 1-1). Corrective Action Unit 124 is comprised of five Corrective Action Sites (CASs) shown on Figure 1-1 and listed below:

- 08-02-01, Underground Storage Tank

- 15-02-01, Irrigation Piping

- 16-02-03, Underground Storage Tank

- 16-02-04, Fuel Oil Piping

- 16-99-04, Fuel Line (Buried) and UST 


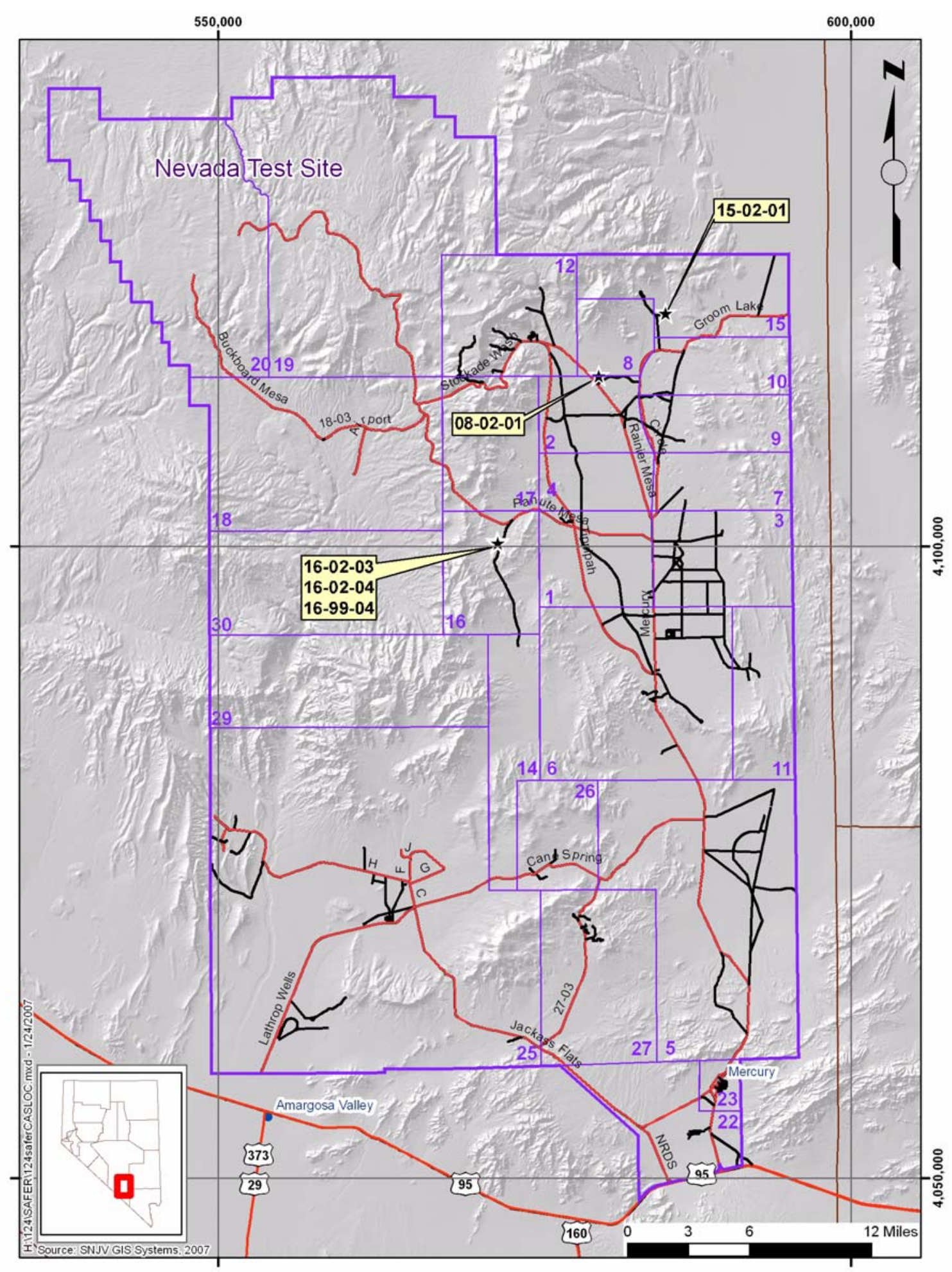

Figure 1-1

Nevada Test Site Map with CAU 124 CAS Locations 
There is sufficient information and process knowledge from historical documentation and investigations of similar sites (i.e., the expected nature and extent of contaminants of potential concern (COPCs) to recommend closure of CAU 124 using the SAFER process (FFACO, 1996).

\subsection{SAFER Process Description}

Corrective action units that may be closed using the SAFER process have conceptual corrective actions that are clearly identified. Consequently, corrective action alternatives can be chosen before completing a CAI, given anticipated investigation results.

The SAFER process combines elements of the DQOs process and the observational approach to plan and conduct closure activities. The DQOs are used to identify the problem and define the type and quality of data needed to complete closure of each CAS. The purpose of the investigation phase is to verify the adequacy of existing information used to determine the chosen corrective action and to confirm that closure objectives were met.

Use of the SAFER process allows for technical decisions to be made based on incomplete but sufficient information, and the experience of the decision-maker. Based on a detailed review of historical documentation, there is sufficient process knowledge to close CAU 124 using the SAFER process. Uncertainties are addressed by documented assumptions that are verified by sampling and analysis, data evaluation, and onsite observations, as necessary. Closure activities may proceed simultaneously with site characterization as sufficient data are gathered to confirm or disprove the assumptions made during selection of the corrective action. If, at any time during the closure process, new information is discovered that indicates that closure activities should be revised, closure activities will be re-evaluated as appropriate.

\subsection{Summary of Corrective Actions and Closures}

The anticipated closure for the CAU 124 CASs are either no further action or clean closure. However, if contaminants of concern (COCs) are identified these specific sites may be closed in place with use restrictions. The decision process for the closure of CAU 124 is summarized in Figure 1-2. This process starts with the initial investigation in which the appropriate target population(s) within each CAS (defined in the DQO process, Appendix B) is sampled. If contaminants are detected at 
concentrations that are above the final action levels (FALs) and remediation is feasible, the nature and extent of contamination will be delineated by additional sampling. However, contingencies are built into the process in the event new information is identified that indicates the selected closure option should be revised. The process ends with closure of the site based on laboratory analytical results of the environmental samples and the preparation of a Closure Report (CR). Corrective action alternatives of closure in place and clean closure will be evaluated for each CAS with contaminants above preliminary action levels (PALs).

Decision points that require a consensus be reached between the NNSA/NSO and NDEP before continuing are indicated in Figure 1-2.

In addition to the previously discussed hold/decision points, work may be temporarily suspended until the issue can be resolved satisfactorily if the following unexpected conditions occur:

- Conditions outside the scope of work are encountered.

- Radiological screening yields results that require an upgrade in procedures to continue survey work in specific areas.

- Elevated levels of additional COCs are found that were not originally identified as present at the sites.

- Unexpected conditions including unexpected waste and/or contamination are encountered.

- $\quad$ Out-of-scope work activities are required due to the detection of other COCs that would require re-evaluating a disposal pathway, such as with hazardous or low level waste.

- Unsafe conditions or work practices. 


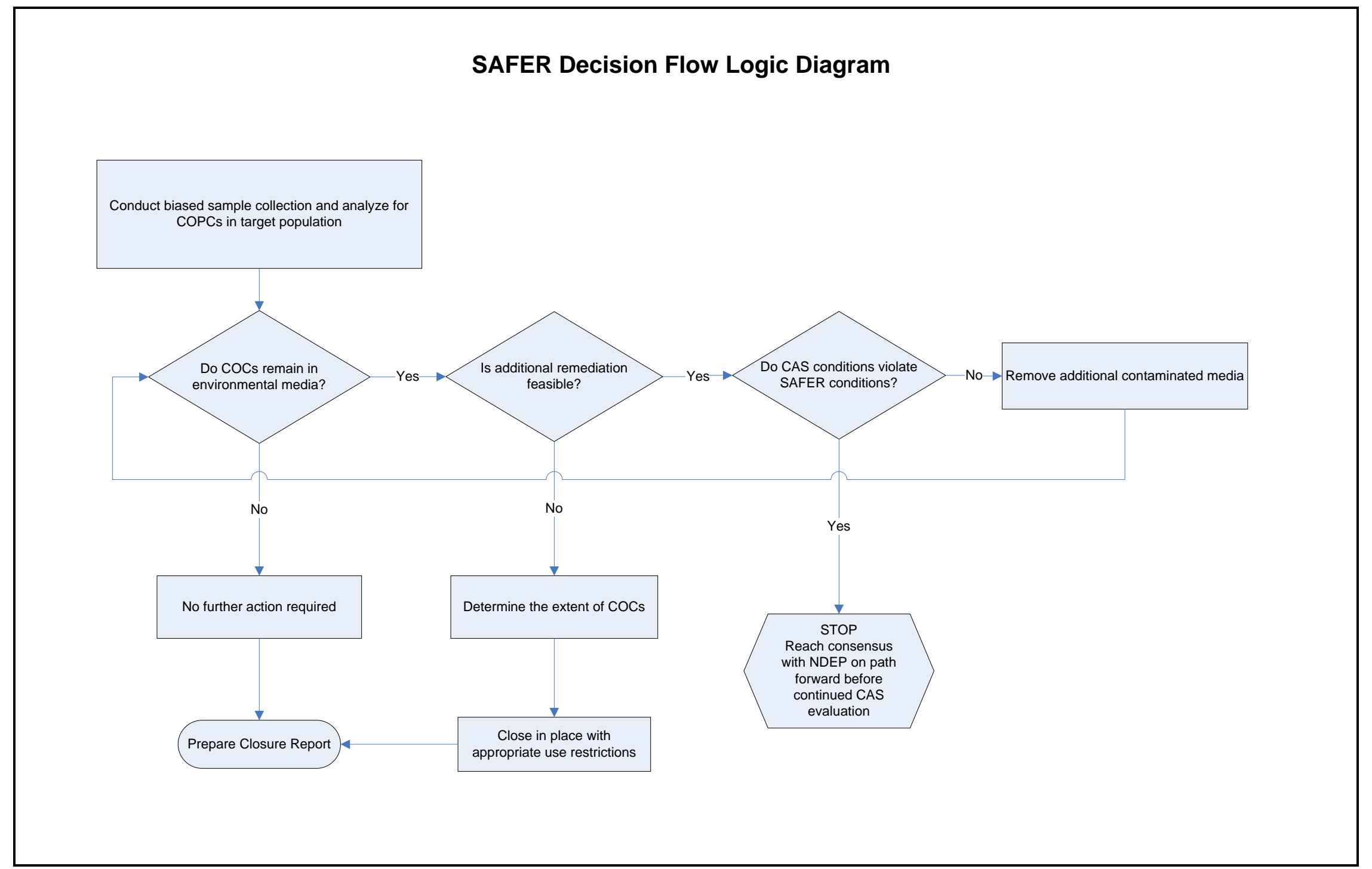

Figure 1-2

CAU 124 Closure Decision Process 


\subsection{Unit Description}

The CASs within CAU 124 are located within Areas 8, 15, and 16 of the NTS (see Figure 1-1). The operational history, process knowledge, and existing information for each CAS is summarized in this section. Process knowledge for the CAU 124 CASs has been obtained through historical document reviews, engineering drawing and map reviews, and interviews with past and present NTS employees. Some uncertainty remains regarding general knowledge of past operations for CAU 124. Site-specific historical documentation pertaining to each CAS is also limited. Based on process knowledge and information about the CASs, assumptions were made to formulate a conceptual site model (CSM) that describes the most probable scenario for the current conditions at each CAS. Section 3.2.5 provides additional information on the CSM developed for the CAU 124 CASs.

\subsection{Corrective Action Site 08-02-01, Underground Storage Tank}

Corrective Action Site 08-02-01 is near the eastern edge of the Area 8 Trailer Park, near Area 2 Camp, in Area 8 of the NTS. The site was first identified in the document entitled, Nevada Test Site Inventory of Inactive and Abandoned Facilities and Waste Sites, as one underground storage tank (UST) with unknown contents and usage (REECo, 1991). The CAS consists of a UST and associated piping at the eastern edge of the Area 8 trailer park. A 4-inch (in.) diameter, gray polyvinyl chloride (PVC) pipe is visibly extending approximately 2 feet (ft) above ground surface. However, it is not known if this pipe is associated with this CAS. The area surrounding the pipe is slightly subsided.

The initial boundaries of CAS 08-02-01 were determined from the original photograph and recent site visit. An original photograph taken in April 1991 showed two pipes close together with caps. However, a more recent site walk revealed the same site with only one pipe and no cap.

Figure 2-1 shows the CAS location with respect to surrounding roads and other physical features. 


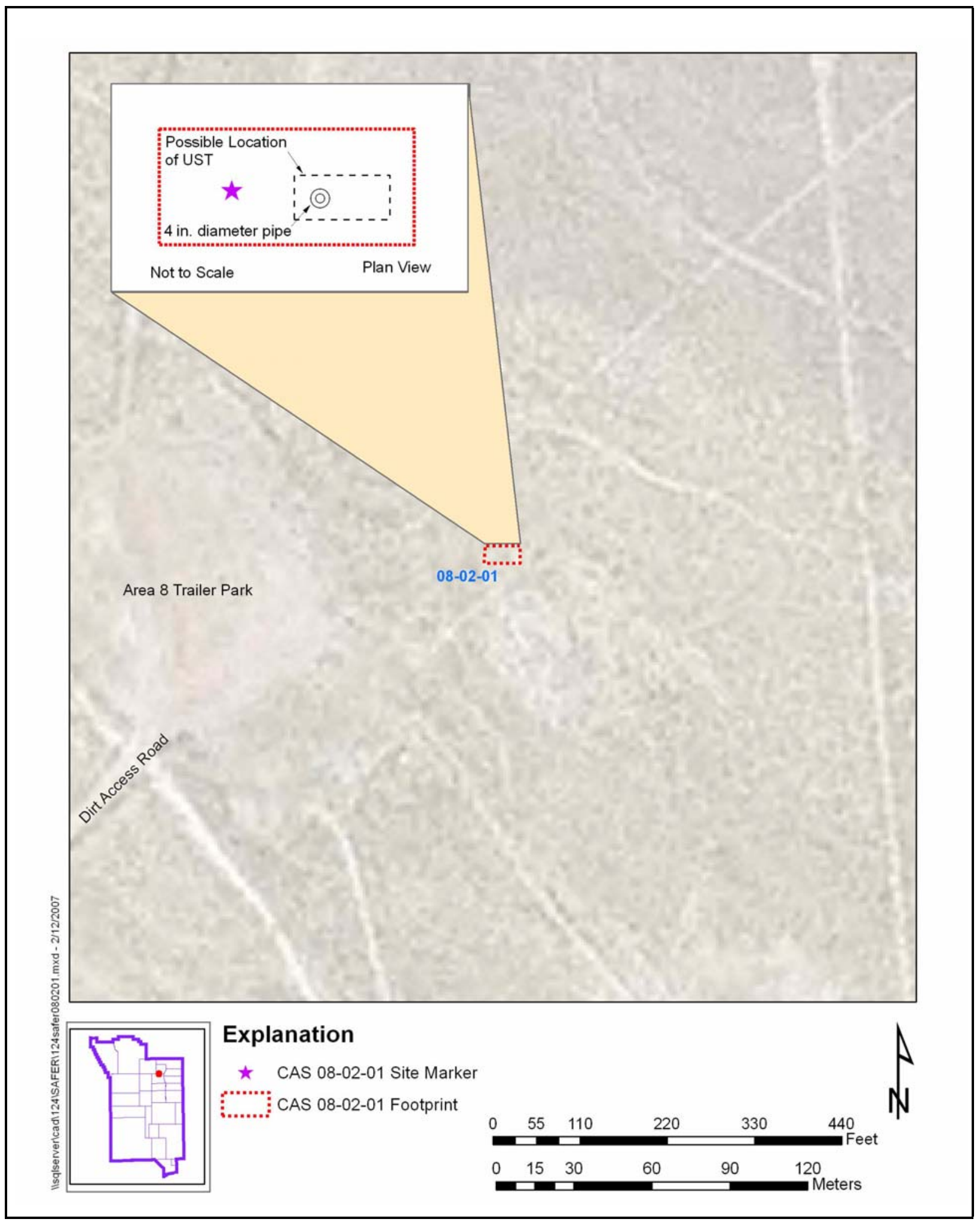

Figure 2-1

CAS 08-02-01 Location, Surrounding Roads, and Physical Features 


\subsubsection{History and Process Knowledge}

The history of CAS 08-02-01 remains uncertain. The UST was likely used to support activities in the Area 8 Trailer Park. The CAS is believed to be a soil gas or borehole gas sampling tank (Madsen, 2006).

\subsubsection{Available Characterization Information}

A geophysical survey was conducted at CAS 08-02-01 in 2003 to identify the possible location of a UST and the depth and location of associated piping. The survey encompassed approximately 3,300 square feet $\left(\mathrm{ft}^{2}\right)$ around the presumed area of the UST. The survey did not identify a UST or detectable underground piping at the site (SAIC, 2003).

A radiological walkover survey was conducted at CAS 08-02-01 in 2003. The survey area encompasses approximately $28,000 \mathrm{ft}^{2}$. The maximum gamma radiation emission rate for CAS 08-02-01 was not distinguishable from local background (less than two times greater than the mean undistributed background gamma radiation rate or the maximum undisturbed background gamma radiation emission rate) (Nicosia, 2003).

\subsection{Corrective Action Site 15-02-01, Irrigation Piping}

Corrective Action Site 15-02-01 consists of two farm plots (Plot A and Plot B), the adjacent concrete pads (formerly the greenhouse and storage shed), and a reservoir located at the U.S. Environmental Protection Agency (EPA) Farm in Area 15 of the NTS. This CAS was first identified in the document entitled, Nevada Test Site Inventory of Inactive and Abandoned Facilities and Waste Sites, as an underground tank, $20 \mathrm{ft}$ northwest of the greenhouse. Plot A, is approximately a 16-acre (960-by-720-ft) area divided into 17 specific lateral sections by irrigation piping. Plot B, is approximately a 5-acre (430-by-225-ft) farm plot divided into eight specific lateral sections by irrigation piping (REECo, 1991).

In 1963 the U.S. Atomic Energy Commission awarded the EPA Farm contract to the U.S. Public Health Service (USPHS) to study the transport of iodine (I) from the environment to humans (SWRHL, 1967; REECo, 1966). Inside the CAS 15-02-01 boundary are two concrete pads in the northwest corner of Plot B, adjacent to the Plot A fence line. The concrete pads are foundations that 
supported a greenhouse and a storage building. The conclusion of the experimental studies on cattle in 1979 lead to more specific animal studies until the end of 1981 when the EPA Farm was closed. Surficial decontamination and decommissioning activities were completed in 1997 that included the removal of the storage shed and the greenhouse structures.

The reservoir that is adjacent to CAS 15-02-01 has been included in this CAS. The reservoir was used to temporarily store water. The water was then pumped into the distribution system to irrigate the fields. There is a concern that the radionuclides used to treat the fields may have been mixed into the water in the reservoir before distribution. Samples from the bottom of the reservoir will be collected to determine if there are residual contaminants from potential mixing activities.

Figure 2-2 shows the CAS location with respect to surrounding roads, buildings, and the CAS boundaries and physical layout.

\subsubsection{History and Process Knowledge}

Radionuclides were used in experiments at the Area 15 EPA Farm, which included I-131 from dry-aerosol tests. The area surrounding the Farm, including CAS 15-02-01, was subject to fallout from the dispersion of radionuclides from the U8d, U10h (Sedan) test, and other atmospheric tests conducted on NTS. Tritium may also be present from metabolism studies conducted at the EPA Farm (SWRHL, 1967; EPA, 1973; Adams, 2002).

The Farm Plots were used by the EPA to study the effects of radiological uptake in plants and the impacts on cattle. Plot A was used to grow forage that was subject to various experimental substances such as I-131, various metals, and fallout from nearby tests (SWRHL, 1967; REECo, 1966).

Plot B may have also been used for experiments and pilot studies that could not be conducted conveniently in the main crop area. However, the exact use of Plot B is unknown.

Historical information on the concrete greenhouse and storage shed foundations are limited. The storage shed may have been used as a holding area for small tools, equipment, and chemicals used on the day-to-day care of the Farm Plots. 
Historical documents reveal that cattle experiments under Project Plum (August 13 to 25, 1969) used forage mixed with lead-203 and used forage mixed with tungsten (W) under Project Wolf II (October 29, 1969, through January 29, 1970) (EPA, 1973). While there is minimal information on these experiments, there is reason to believe there could be metals contamination present in the soils.

Further research was conducted looking into the potential environmental impact from either radioactive or non-radioactive tungsten as a COPC. Tungsten is a relatively nontoxic element, and there are no EPA Region 9 Risk-Based Preliminary Remediation Goals (PRGs) established (EPA, 2004). Tungsten is not listed in 40 Code of Federal Regulations (CFR) 261 Appendix VIII or the 40 CFR 264 Appendix IX list (CFR, 2006a). Therefore, it is not considered to be problematic by EPA from either a risk or waste standpoint.

The radioactive tungsten was also researched. Naturally occurring tungsten consist of five isotopes whose half-lives are so long that they can be considered stable. Twenty-seven radioisotopes of tungsten have been characterized, the most stable of which are W-181 with a half-life of 121.2 days, W-185 with a half-life of 75.1 days, W-188 with a half-life of 69.4 days, and W-178 with a half-life of 21.6 days. All of the remaining radioactive isotopes have half-lives of less than 24 hours, and most of these have half-lives that are less than 8 minutes.

If non-radioactive tungsten was used in the EPA experiments, then there is no known potential toxicity. If radioisotopes of tungsten were used, they would have decayed away in the 30-plus years since they were used, and there would be no traces remaining at the site.

Therefore, tungsten was not added as a COPC for the EPA Farm plots. 


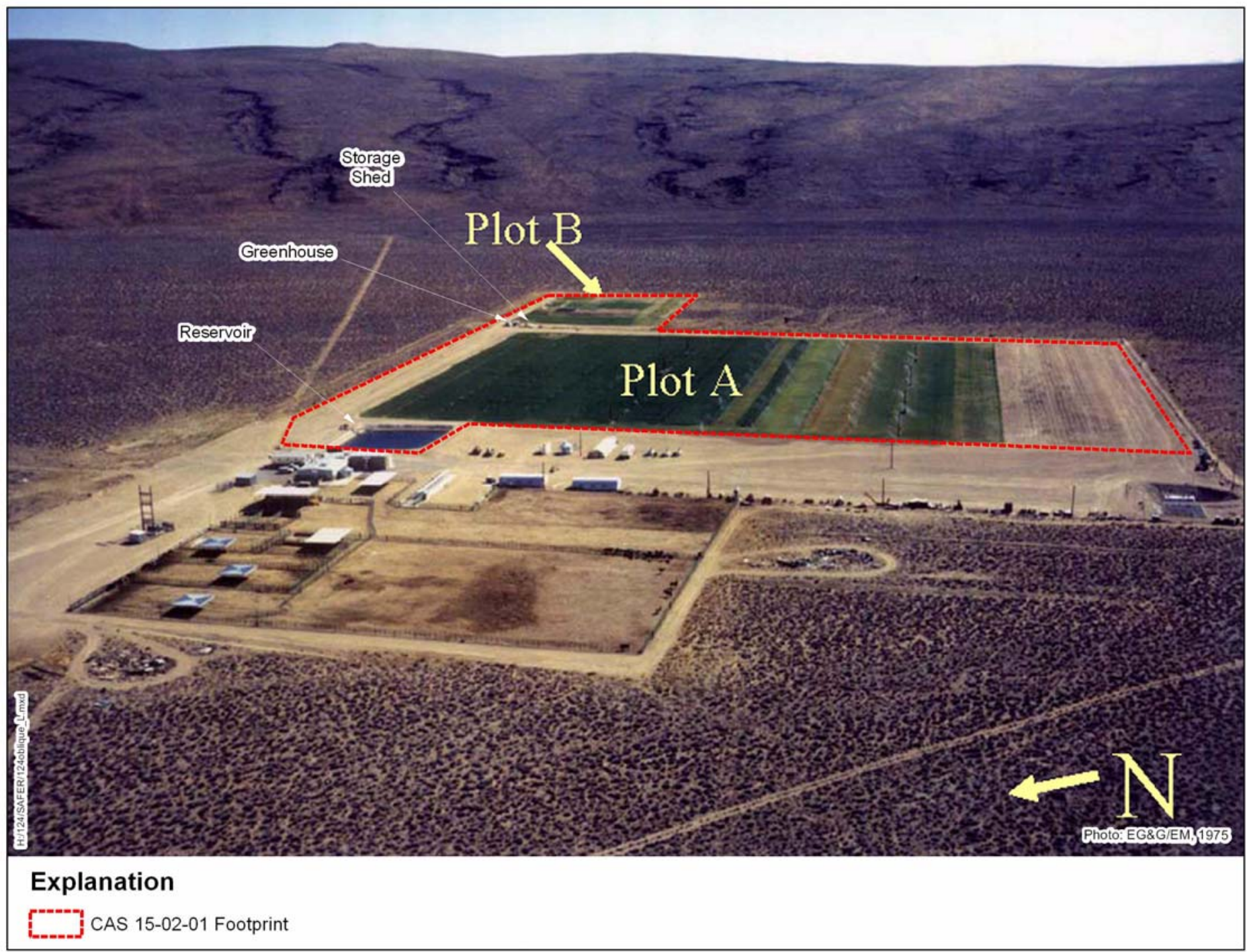

Figure 2-2

Oblique Photo Showing CAS 15-02-01 Roads, Buildings, CAS Boundary and Physical Layout 


\subsubsection{Available Characterization Information}

In April 2006, a geophysical survey was performed at CAS 15-02-01 that encompassed both Plot A and Plot B, approximately 11,900 $\mathrm{ft}^{2}$. This survey revealed obvious anomalies consistent with the irrigation piping as well as with steel reinforcement of the northern concrete pad (greenhouse); however, no readings indicating a UST were detected in the area.

There has been no soil sampling performed on the EPA Farm Plots. However, a demarcation survey of the EPA Farm area conducted on August 6, 1998, indicated that contamination at the soil surface was below Appendix D, 10 CFR 835, values (DOE/NV, 2000). A walkover survey conducted in November 2006 showed that the area was uniformly less than or equal to two times the background count rate.

\subsection{Corrective Action Site 16-02-03, Underground Storage Tank}

Corrective Action Site 16-02-03 is an underground storage tank located within the Area 16 Camp. The camp, built between 1960 and 1962, included 52 housing trailers, a kitchen and dining complex, and a recreation complex.

Corrective Action Site 16-02-03 was originally identified in the document entitled, Nevada Test Site Inventory of Inactive and Abandoned Facilities and Waste Sites, as a possible UST (REECO, 1991).

Figure 2-3 shows CAS 16-02-03 location with respect to Area 16 Camp, CAS 16-02-04 and 16-99-04, and surrounding roads and other physical features. Figure 2-4 shows the CAS site conditions and physical layout.

\subsubsection{History and Process Knowledge}

The exact use of this CAS is unknown. Historical documents reveal that the camp was used for personnel that supported the operations located at the Area 16 tunnels (Metcalf, 2004). According to engineering drawings, the UST could be part of a water system designed to carry water to the trailers or part of a fuel oil system in the Area 16 Camp (REECo, 1962). The actual UST is not on the engineering drawings located for CAS 16-02-03 or the Area 16 Camp. The camp was demolished between 1969 and 1970 . 


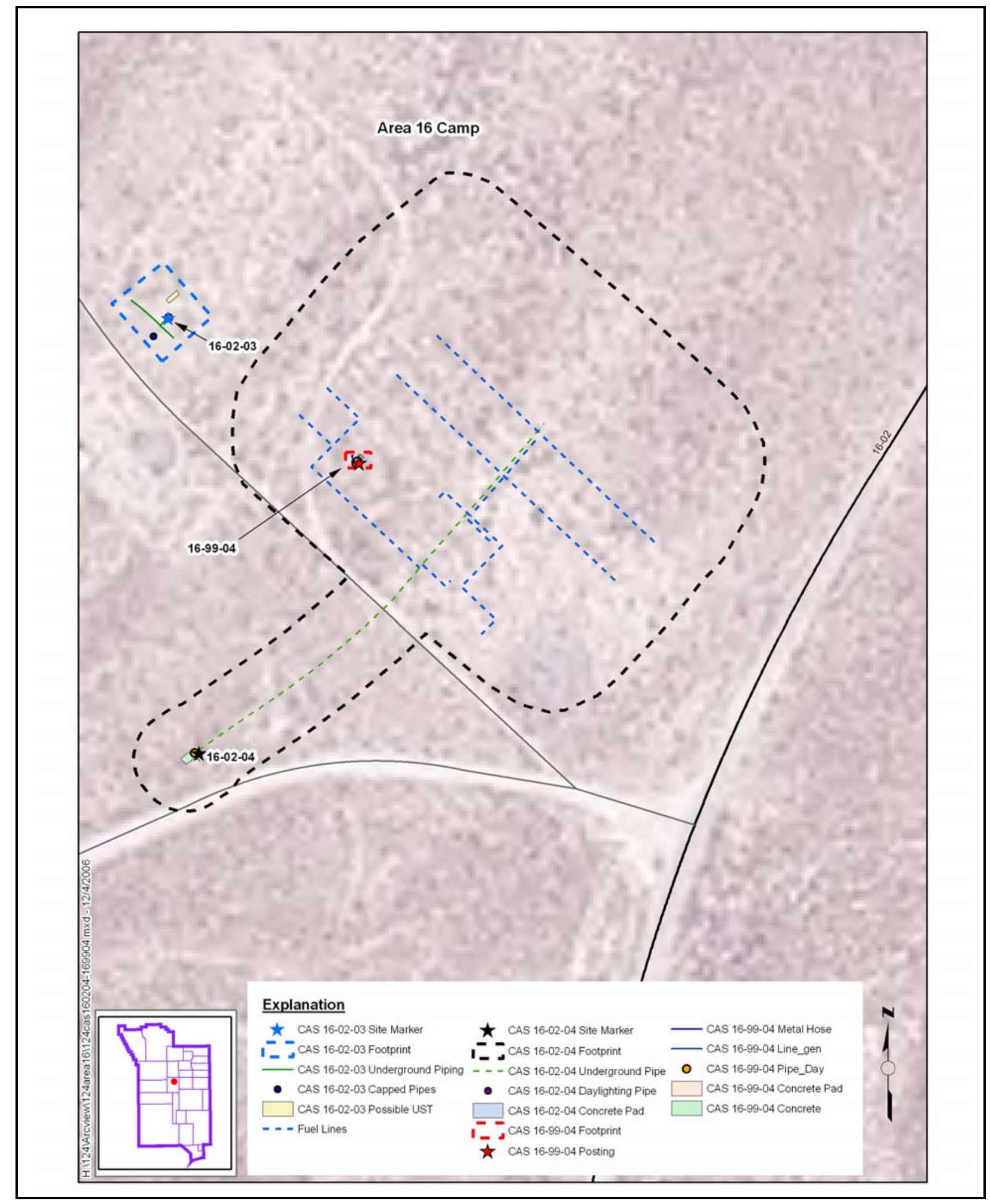

Figure 2-3

Area 16 CASs 16-02-03, 16-02-04, and 16-99-04 Surrounding Roads and Other Physical Features 


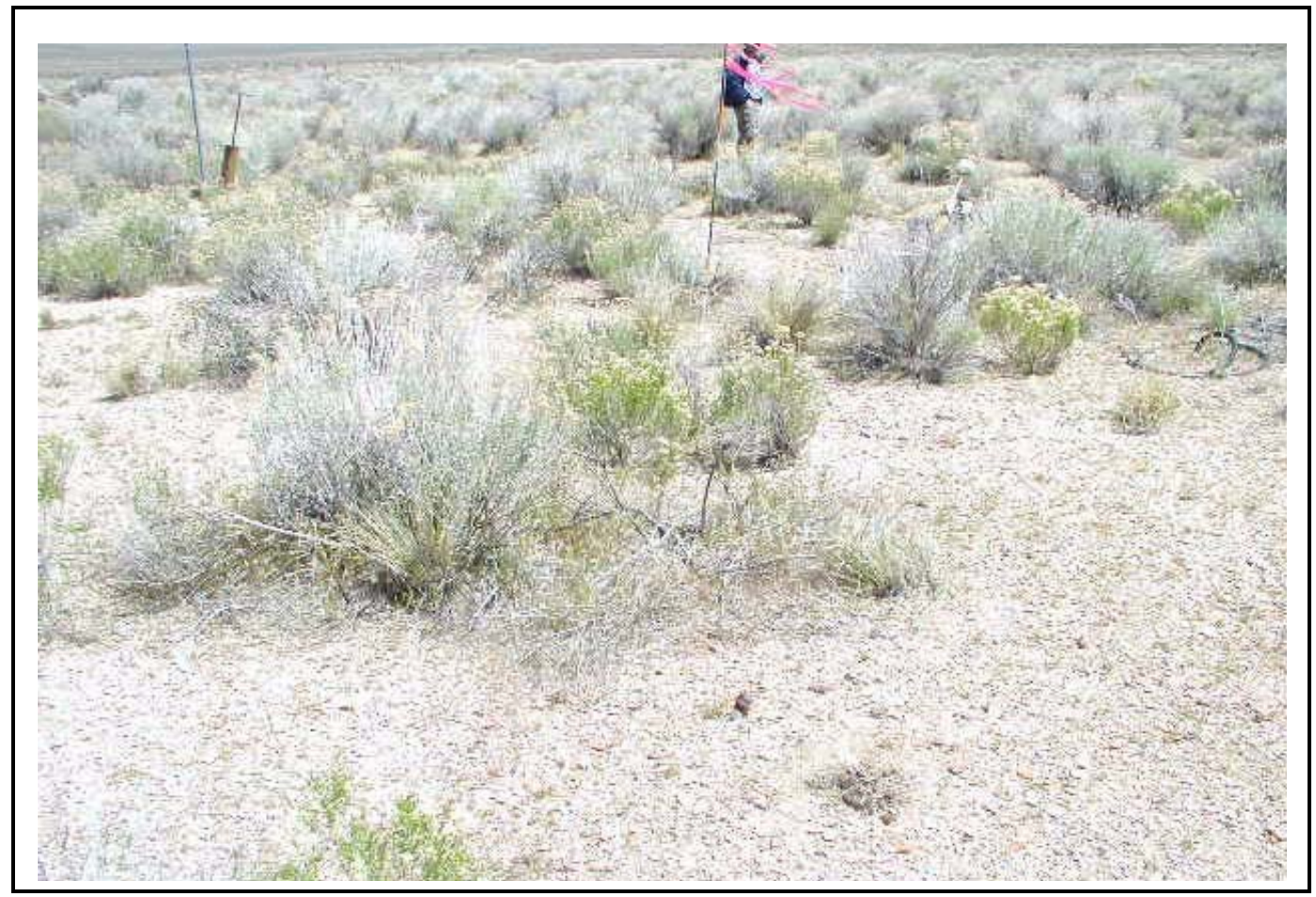

Figure 2-4

\section{CAS 16-02-03, Site Conditions and Physical Layout}

\subsubsection{Available Characterization Information}

There are no analytical data for CAS 16-02-03. However, a 2003 geophysical survey revealed the possible location of the UST, the depth, and the location of associated piping. The survey encompassed approximately 3,000 $\mathrm{ft}^{2}$. Four anomalies were identified during the EM61 survey (SAIC, 2003). Figure 2-5 depicts the four anomalies labeled “A,” "B,” "C,” and "D.” Anomaly “A” is a linear anomaly that can be interpreted as underground piping. Anomalies " $\mathrm{B}$," "C," and " $\mathrm{D}$ " are rectangular in shape and located near surface vent pipes. It is noted in the survey report that these anomalies exhibit reflections consistent with a UST, although not definitely identified (SAIC, 2003).

There has been no radiological survey performed at CAS 16-02-03. 


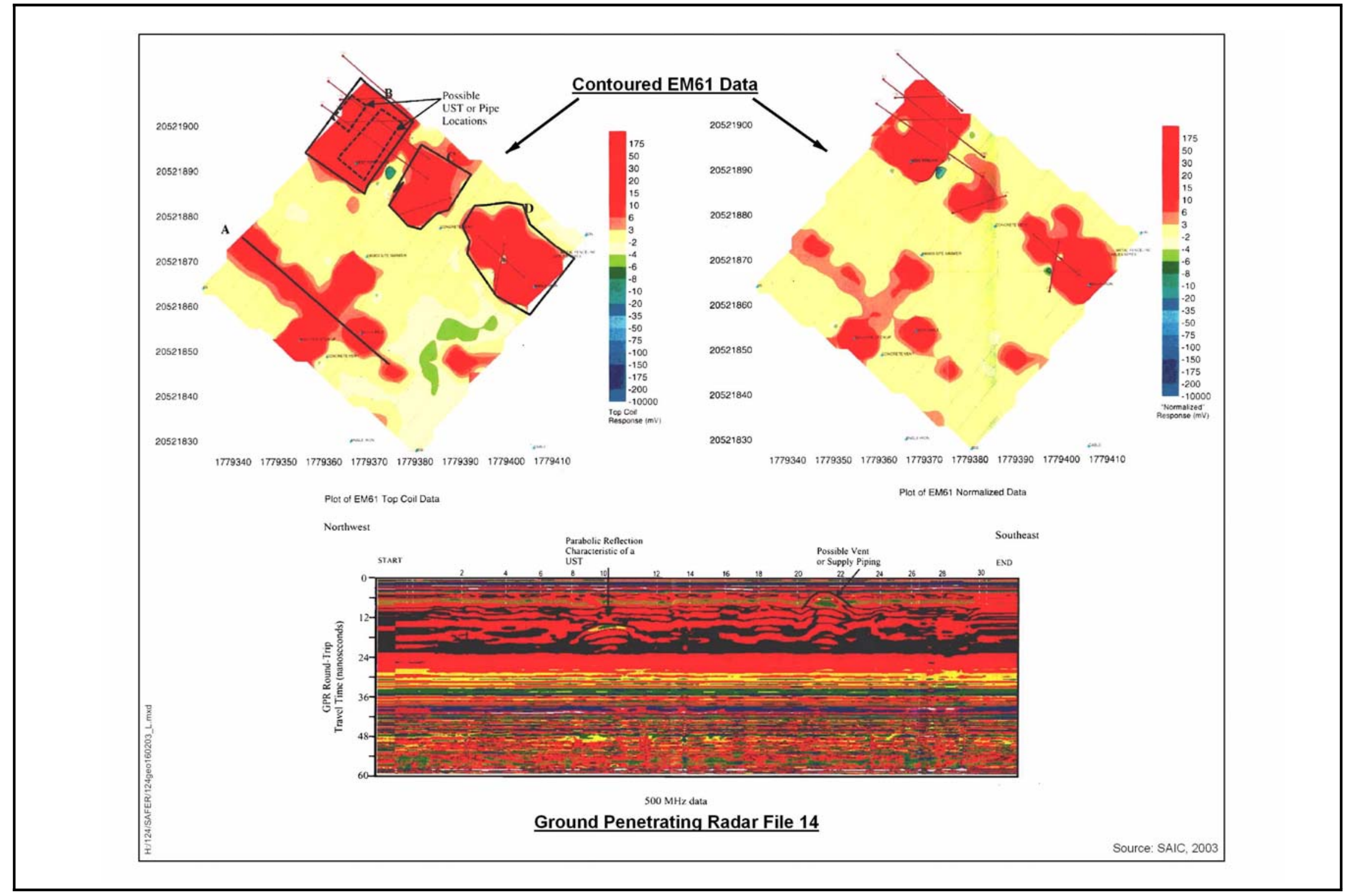

Figure 2-5

CAS 16-02-03, Science Applications International Corporation Geophysical Survey 


\subsection{Corrective Action Site 16-02-04, Fuel Oil Piping}

Corrective Action Site 16-02-04 was identified in the document entitled, Nevada Test Site Inventory of Inactive and Abandoned Facilities and Waste Sites, as fuel oil piping (REECo, 1991). According to historical documentation and a recent informal utility survey, CAS 16-02-04 consists of fuel oil piping that was connected to a former 2,000-gallon (gal) fuel oil aboveground storage tank (AST) (REECo, 1962).

Figure 2-3 shows CAS 16-02-04 location with respect to Area 16 Camp, CAS 16-02-03 and 16-99-04, with respect to surrounding roads and other physical features. Figure 2-6 shows the CAS site conditions and physical layout.

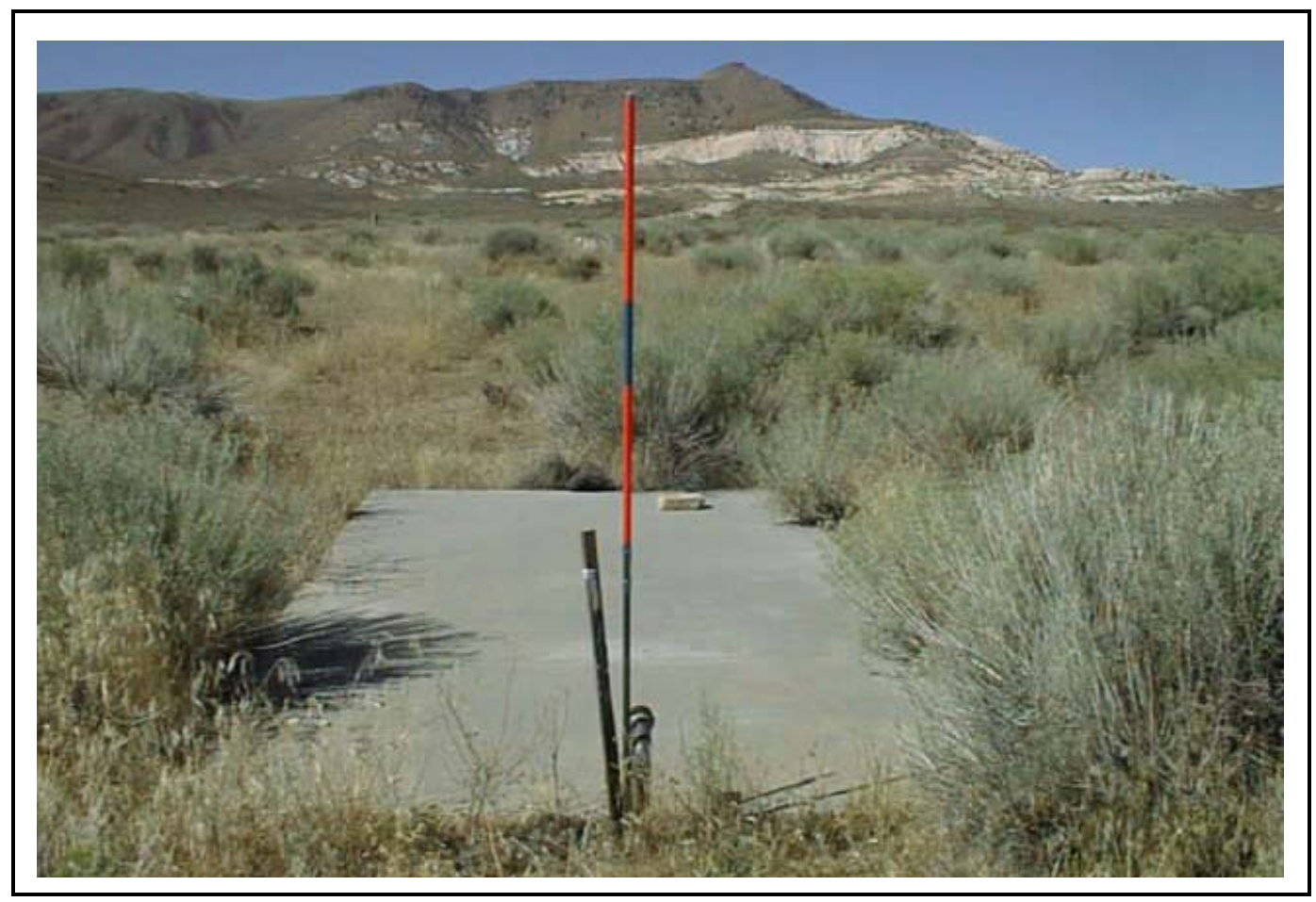

Figure 2-6

CAS 16-02-04, Site Conditions and Physical Layout 


\subsubsection{History and Process Knowledge}

The Area 16 Camp was constructed between 1960 and 1962. The camp was used as a housing and recreation complex for personnel working at the Area 16 tunnels during the 1960s. The Area 16 Camp consisted of a 52-trailer facility, a kitchen and dining complex, and a recreation complex. The Camp was dismantled sometime between the mid-1960s and 1972. The specific history of CAS 16-02-04 is unknown. Engineering drawings show there is approximately $950 \mathrm{ft}$ of fuel oil piping still in place (REECo, 1962). Historical documents reveal that the fuel oil line was connected to a 2,000-gal AST that was positioned on the currently existing concrete pad (REECo, 1962). It is unknown when the fuel oil AST was removed or if there were releases of contamination from the AST or associated fuel oil piping.

\subsubsection{Available Characterization Information}

A geophysical survey performed in 2003 was conducted to determine the presence of a UST. The survey was inconclusive due to interference from the concrete pad associated with CAS 16-02-04; however, subsurface piping was found (SAIC, 2003). Furthermore, according to the survey, there is approximately $950 \mathrm{ft}$ of subsurface fuel oil piping still in place.

There are no analytical data available for CAS 16-02-04. Based on process knowledge, the suspect COPCs are petroleum hydrocarbons.

There has been no radiological survey performed on CAS 16-02-04.

\subsection{Corrective Action Site 16-99-04, Fuel Line (Buried) and UST}

Corrective action site 16-99-04 identified in the document entitled, Nevada Test Site Inventory of Inactive and Abandoned Facilities and Waste Sites, as a Fuel Line (Buried) and UST (REECo, 1991). A wooden post with a sign that reads "Fuel Line 18' Deep”; a 2-in. diameter, L-shaped metal pipe with a turn valve; a metal hose approximately $6 \mathrm{ft}$ in length exposed on the ground surface; a 1-in. diameter vent pipe; a concrete pad and a UST are within the area of the CAS. 
Figure 2-3 shows CAS 16-99-04 location with respect to Area 16 Camp, CAS 16-02-03 and 16-02-04, with respect to surrounding roads and other physical features. Figure 2-7 shows the CAS site conditions and physical layout.

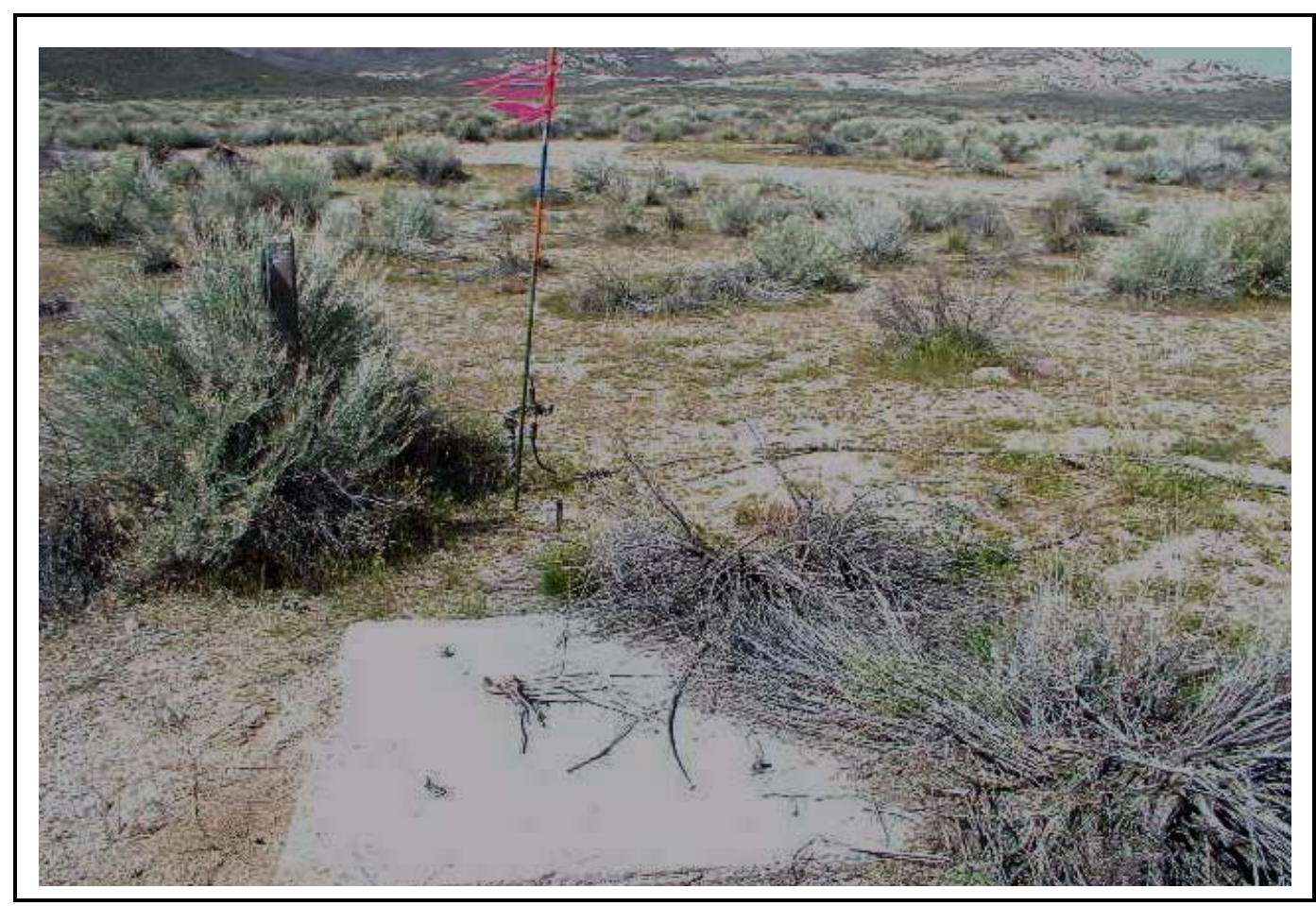

Figure 2-7

CAS 16-99-04, Site Conditions and Physical Layout

\subsubsection{History and Process Knowledge}

The Area 16 Camp was constructed between 1960 and 1962. The camp was used as a housing and recreation complex for personnel working at the Area 16 tunnels during the 1960s. The Area 16 Camp consisted of a 52-trailer facility, a kitchen and dining complex, and a recreation complex. The Camp was dismantled sometime between the mid-1960s and 1972. The specific history of CAS 16-99-04 is unknown. Historical documentation makes reference to Area 16 ASTs and USTs; however, nothing specific about CAS 16-99-04 (REECo, 1962). 


\subsubsection{Available Characterization Information}

There are no analytical data available for CAS 16-99-04. Based on process knowledge, the suspect COPCs are petroleum hydrocarbons.

There have been no radiological surveys performed at CAS 16-99-04.

A 2003 geophysical survey identified a UST and subsurface piping at CAS 16-99-04 and inductively traced some of the piping back to CAS 16-02-04 (Fuel Oil Piping) (SAIC, 2003). Figure 2-8 shows the contoured EM61 survey data. Two of the four identified anomalies, "A" and "B" are linear and can be interpreted to represent underground metallic piping. Anomaly " $\mathrm{C}$ " is rectangular. This anomaly is similar in size, shape, and magnitude to a UST or vault. Anomaly " $\mathrm{D}$ " is not associated with visible surface metals but does not have the amplitude consistent with a typical UST (SAIC 2003). 


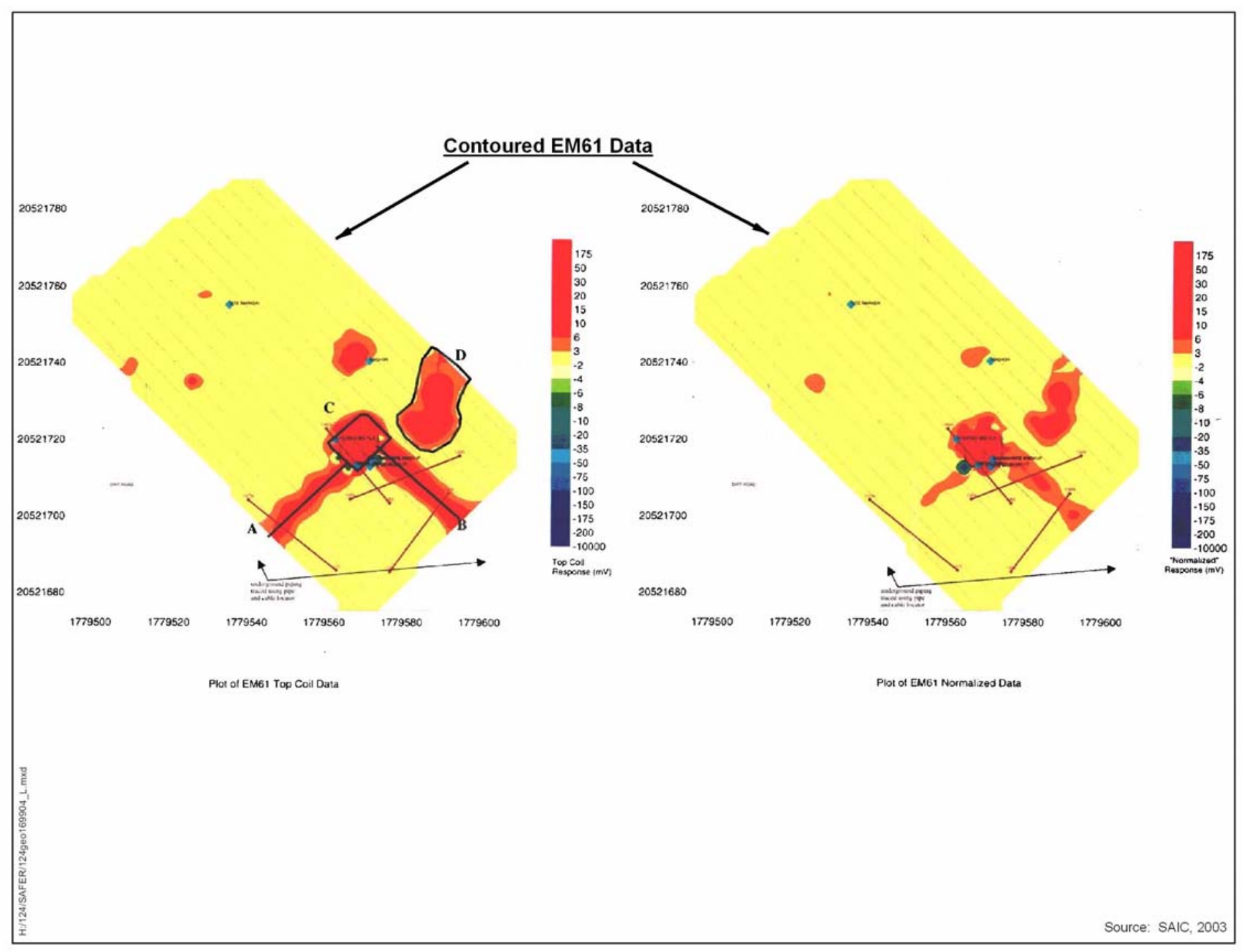

Figure 2-8

CAS 16-99-04, Science Applications International Corporation Geophysical Survey 


\subsection{Data Quality Objectives}

\subsection{Summary of DQO Analysis}

This section contains a summary of the DQO process that is presented in Appendix B. The DQO process is a strategic planning approach based on the scientific method that is designed to ensure that the data collected will provide sufficient and reliable information to identify, evaluate, and technically defend the recommendation of viable corrective actions (e.g., no further action, clean closure, or closure in place).

The DQO strategy for CAU 124 was developed at a meeting on December 14, 2006. The DQOs were developed to identify data needs, clearly define the intended use of the environmental data, and to design a data collection program that will satisfy these purposes. During the DQO discussions for this CAU, the informational inputs or data needs to resolve problem statements and decision statements were documented.

The problem statement for CAU 124 is: "Existing information on the nature and extent of potential contamination is insufficient to validate the assumptions used to select the corrective actions or to verify that closure objectives were met for the CASs in CAU 124.” To address this question, the resolution of two decisions statements is required:

- Decision I: “Is any COC present in environmental media?” For the judgmental sampling design, any analytical result for a COPC above the FAL will result in that COPC being designated as a COC.

- Decision II: "Is sufficient information available to confirm that closure objectives were met?" Sufficient information is defined to include:

- Identifying the lateral and vertical extent of COC contamination in environmental media, if present

- The information needed to characterize IDW for disposal

- The information needed to determine remediation waste types

The presence of a COC would require a corrective action. A corrective action may also be necessary if there is a potential for wastes present at a site to impose COCs into site environmental media, if 
wastes were released. To evaluate the potential for site wastes to result in the introduction of a COC to the surrounding environmental media, the following conservative assumptions were made:

- Containment of the wastes (e.g., tank) would fail at some point and the wastes would be released to the surrounding media.

- The resulting concentration of contaminants in the surrounding media would be equal to the concentration of contaminants in the waste.

- Liquid waste contaminant concentrations exceeding the Resource Conservation and Recovery Act (RCRA) toxicity characteristic concentration would result in COCs in the surrounding media.

Waste solids containing a contaminant exceeding an equivalent FAL concentration would be considered to be potential source material and would require a corrective action. Waste liquids with contaminant concentrations exceeding an equivalent toxicity characteristic action level would be considered to be potential source material and would require a corrective action.

Decision I samples will be submitted to analytical laboratories for the analyses listed in Table 3-1. The constituents reported for each analytical method are listed in Table 3-2.

Table 3-1

Analytical Program ${ }^{a}$

(Includes Waste Characterization Analyses)

(Page 1 of 2)

\begin{tabular}{|c|c|c|c|c|c|}
\hline Analyses $^{b}$ & $\begin{array}{l}\text { 엄 } \\
\text { Ñ } \\
\text { ò } \\
\text { o }\end{array}$ & 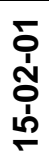 & 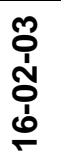 & 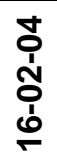 & 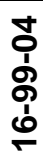 \\
\hline \multicolumn{6}{|c|}{ Organic COPCs } \\
\hline Total Petroleum Hydrocarbons-Diesel-Range Organics & $x$ & & $x$ & $\mathrm{x}$ & $\mathrm{x}$ \\
\hline Total Petroleum Hydrocarbons-Gasoline-Range Organics & & & & & $x$ \\
\hline Polychlorinated Biphenyls & $x$ & & $x$ & & \\
\hline Semivolatile Organic Compounds ${ }^{c}$ & $x$ & $x$ & $x$ & $x$ & $x$ \\
\hline Volatile Organic Compounds ${ }^{c}$ & $\mathrm{x}$ & $x$ & $x$ & $x$ & $x$ \\
\hline Pesticides $^{c}$ & & $x$ & & & \\
\hline Herbicides $^{c}$ & & $\mathrm{x}$ & & & \\
\hline
\end{tabular}


Table 3-1

Analytical Program ${ }^{a}$

(Includes Waste Characterization Analyses)

(Page 2 of 2)

\begin{tabular}{|c|c|c|c|c|c|}
\hline Analyses $^{b}$ & 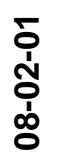 & 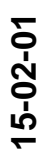 & $\begin{array}{l}\text { @o } \\
\stackrel{1}{ } \\
\text { ஸे } \\
\text { فे }\end{array}$ & 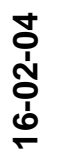 & 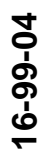 \\
\hline \multicolumn{6}{|c|}{ Inorganic COPCs } \\
\hline Total Resource Conservation and Recovery Act Metals ${ }^{c}$ & $\mathrm{X}$ & $\mathrm{X}$ & $\mathrm{X}$ & & \\
\hline \multicolumn{6}{|c|}{ Radionuclide COPCs } \\
\hline Gamma Spectroscopy $^{d}$ & $\mathrm{x}$ & $\mathrm{X}$ & $\mathrm{X}$ & & \\
\hline \multicolumn{6}{|l|}{ Isotopic Uranium } \\
\hline \multicolumn{6}{|l|}{ Isotopic Plutonium } \\
\hline \multicolumn{6}{|l|}{ Strontium-90 } \\
\hline Tritium & & $\mathrm{x}$ & & & \\
\hline \multicolumn{6}{|c|}{ Waste Characterization Analyses } \\
\hline Gross Alpha/Beta (Aqueous only) & $\mathrm{x}$ & $\mathrm{x}$ & $\mathrm{X}$ & $\mathrm{X}$ & $\mathrm{X}$ \\
\hline Tritium & $x$ & $\mathrm{X}$ & $\mathrm{X}$ & $\mathrm{X}$ & $\mathrm{X}$ \\
\hline Gamma Spectroscopy & $x$ & $x$ & $X$ & $x$ & $x$ \\
\hline Isotopic Uranium ${ }^{\mathrm{e}}$ & $x$ & $x$ & $x$ & $x$ & $x$ \\
\hline Isotopic Plutonium ${ }^{\mathrm{e}}$ & $x$ & $x$ & $x$ & $x$ & $x$ \\
\hline Strontium- $90^{\mathrm{e}}$ & $x$ & $x$ & $\mathrm{X}$ & $\mathrm{X}$ & $x$ \\
\hline
\end{tabular}

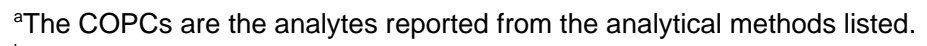

'If the volume of material is limited, prioritization of the analyses will be necessary.

'May also include Toxicity Characteristic Leaching Procedure analytes if sample is collected for waste management purposes.

${ }^{\mathrm{d}}$ Results of gamma analysis will be used to determine if further radioanalytical analysis is warranted.

eOnly required to collect if physically solid waste is generated that has the potential constituent.

COPC $=$ Contaminant of potential concern

$\mathrm{X}=$ Required analytical method 
Table 3-2

Analytes Reported by Analytical Methods

\begin{tabular}{|c|c|c|c|c|c|c|c|c|}
\hline \multicolumn{2}{|c|}{ VOC } & svoc & TPH & РСB & Metals & Herbicides & Pesticides & Radionuclides \\
\hline $\begin{array}{l}\text { 1,1,1-Trichloroethane } \\
\text { 1,1,1,2-Tetrachloroethane } \\
\text { 1,1,2,2-Tetrachloroethane } \\
\text { 1,1,2-Trichloroethane } \\
\text { 1,1-1-ichloroethane } \\
\text { 1,1-Dichloroethene } \\
\text { cis-1,2-Dichloroethene } \\
\text { 1,2-Dichloroethane } \\
\text { 1,2-Dichloropropane } \\
\text { 1,2,4-Trichlorobenzene } \\
\text { 1,2,4-Trimethylbenzene } \\
\text { 1,2-Dibromo-3-chloropropane } \\
\text { 1,3,5-Trimethylbenzene } \\
\text { 1,4-Dioxane } \\
\text { 2-Butanone } \\
\text { 2-Chlorotoluene } \\
\text { 2-Hexanone } \\
\text { 4-Methyl-2-pentanone } \\
\text { Acetone } \\
\text { Acetonitrile } \\
\text { Allyl chloride } \\
\text { Benzene } \\
\text { Bromodichloromethane } \\
\text { Bromoform } \\
\text { Bromomethane } \\
\text { Carbon disulfide } \\
\text { Carbon tetrachloride } \\
\text { Chlorobenzene } \\
\text { Chlooethane } \\
\text { Chloroform } \\
\text { Chloromethane } \\
\text { Chloroprene } \\
\text { Dibromochloromethane } \\
\text { Dichlorodifluoromethane } \\
\text { Ethyl methacrylate } \\
\text { Ethylbenzene } \\
\text { Isobutyl alcohol } \\
\text { Isopropylbenzene } \\
\text { m-Dichlorobenzene (1,3) } \\
\text { Methacrylonitrile } \\
\text { Methyl methacrylate }\end{array}$ & $\begin{array}{l}\text { Methylene chloride } \\
\text { N-Butylbenzene } \\
\text { N-Propylbenzene } \\
\text { o-Dichlorobenzene }(1,2) \\
\text { p-Dichlorobenzene }(1,4) \\
\text { p-isopropyltoluene } \\
\text { sec-Butylbenzene } \\
\text { Styrene } \\
\text { tert-Butylbenzene } \\
\text { Tetrachloroethene } \\
\text { Toluene } \\
\text { Total Xylenes } \\
\text { Trichloroethene } \\
\text { Trichlorofluoromethane } \\
\text { Vinyl acetate } \\
\text { Vinyl chloride }\end{array}$ & $\begin{array}{l}\text { 2,3,4,6-Tetrachlorophenol } \\
\text { 2,4-Dimethylphenol } \\
\text { 2,4-Dinitrotoluene } \\
\text { 2,4,5-Trichlorophenol } \\
\text { 2,4,6-Trichlorophenol } \\
\text { 2-Chlorophenol } \\
\text { 2-Methylnaphthalene } \\
\text { 2-Methylphenol } \\
\text { 2-Nitrophenol } \\
\text { 3-Methylphenola } \\
\text { 4-Chloroaniline } \\
\text { 4-Methylphenol } \\
\text { 4-Nitrophenol } \\
\text { Acenaphthene } \\
\text { Acenaphthylene } \\
\text { Aniline } \\
\text { Anthracene } \\
\text { Benzo(a)anthracene } \\
\text { Benzo(a)pyrene } \\
\text { Benzo(b)fluoranthene } \\
\text { Benzo(g,h,i)perylene } \\
\text { Benzo(k)fluoranthene } \\
\text { Benzoic Acid } \\
\text { Benzyl Alcohol } \\
\text { Bis(2-ethylhexyl) phthalate } \\
\text { Butyl benzyl phthalate } \\
\text { Carbazole } \\
\text { Chrysene } \\
\text { Dibenzo(a,h)anthracene } \\
\text { Dibenzofuran } \\
\text { Diethyl Phthalate } \\
\text { Dimethyl phthalate } \\
\text { Di-n-butyl phthalate } \\
\text { Di-n-octyl phthalate } \\
\text { Fluoranthene } \\
\text { Fluorene } \\
\text { Hexachlorobenzene } \\
\text { Hexachlorobutadiene } \\
\text { Hexachloroethane } \\
\text { Indeno(1,2,3-cd)pyrene } \\
\text { Naphthalene } \\
\text { Nitrobenzene } \\
\text { N-Nitroso-di-n-propylamine } \\
\text { Pentachlorophenol } \\
\text { Phenanthrene } \\
\text { Phenol } \\
\text { Pyrene } \\
\text { Pyridine } \\
\end{array}$ & $\begin{array}{l}\text { TPH } \\
\text { (Diesel-Range } \\
\text { Organics } \\
\text { and } \\
\text { (Gasoline-Range } \\
\text { Organics) }\end{array}$ & $\begin{array}{l}\text { Aroclor } 1016 \\
\text { Aroclor } 1221 \\
\text { Aroclor } 1232 \\
\text { Aroclor } 1242 \\
\text { Aroclor } 1248 \\
\text { Aroclor } 1254 \\
\text { Aroclor } 1260 \\
\text { Aroclor } 1268\end{array}$ & $\begin{array}{l}\text { Arsenic } \\
\text { Barium } \\
\text { Cadmium } \\
\text { Chromium } \\
\text { Lead } \\
\text { Mercury } \\
\text { Selenium } \\
\text { Silver }\end{array}$ & $\begin{array}{l}\text { 2,4,5-T } \\
\text { 2,4,5-TP Silvex } \\
\text { 2,4-D } \\
\text { 2,4-DB } \\
\text { DALAPON } \\
\text { DICAMBA } \\
\text { DICHLOROPROP } \\
\text { DINOSEB } \\
\text { MCPA } \\
\text { MCPP }\end{array}$ & $\begin{array}{l}\text { 4,4'-DDD } \\
\text { 4,4'-DDE } \\
\text { 4,4'-DDT } \\
\text { Aldrin } \\
\text { Alpha-BHC } \\
\text { Alpha-Chlordane } \\
\text { Beta-BHC } \\
\text { Chlordane (Technical) } \\
\text { Delta-BHC } \\
\text { Dieldrin } \\
\text { Endosulfan I } \\
\text { Endosulfan II } \\
\text { Endosulfan Sulfate } \\
\text { Endrin } \\
\text { Endrin Aldehyde } \\
\text { Endrin Ketone } \\
\text { Gamma-BHC } \\
\text { Gamma-Chlordane } \\
\text { Heptachlor } \\
\text { Heptachlor Epoxide } \\
\text { Methoxychlor } \\
\text { Toxaphene }\end{array}$ & $\begin{array}{l}\text { Plutonium-238 } \\
\text { Plutonium-239/240 } \\
\text { Strontium-90 } \\
\text { Uranium-234 } \\
\text { Uranium-235 } \\
\text { Uranium-238 } \\
\text { Tritium } \\
\text { Gross Alpha/Beta } \\
\\
\text { Gamma-emitting } \\
\text { radionuclides } \\
\\
\text { Actinium-228 } \\
\text { Americium-241 } \\
\text { Cobalt-60 } \\
\text { Cesium-137 } \\
\text { Europium-152 } \\
\text { Europium-154 } \\
\text { Europium-155 } \\
\text { Lead-212 } \\
\text { Lead-214 } \\
\text { Niobium-94 } \\
\text { Potassium-40 } \\
\text { Thallium-208 } \\
\text { Thorium-234 } \\
\text { Uranium-235 }\end{array}$ \\
\hline
\end{tabular}


The list of COPCs is intended to encompass all of the contaminants that could potentially be present at each CAS. These COPCs were identified during the planning process through the review of site history, process knowledge, personal interviews, past investigation efforts (where available), and inferred activities associated with the CASs. Contaminants detected at other similar or other NTS sites were also included in the COPC list to reduce the uncertainty about potential contamination at the CAS, because complete information regarding activities performed at the CAU 124 sites is not available.

During the review of site history documentation, process knowledge information, personal interviews, and inferred activities associated with the CASs, some of the COPCs were identified as targeted contaminants at specific CASs. Targeted contaminants are those COPCs for which evidence in the available site and process information suggests they may be reasonably suspected to be present at a given CAS. The targeted contaminants are required to meet a more stringent completeness criteria than other COPCs thus providing greater protection against a decision error. Targeted contaminants for each CAU 124 CAS are identified in Table 3-3.

Decision II samples will be submitted for the analysis of all unbounded COCs. In addition, samples will be submitted for analyses as needed to support waste management or health and safety decisions.

The data quality indicators (DQIs) of precision, accuracy, representativeness, completeness, comparability, and sensitivity needed to satisfy DQO requirements are discussed in Section 7.2. Laboratory data will be assessed in the CR to confirm or refute the CSM and determine if the DQO data needs were met.

To satisfy the DQI of sensitivity (presented in Section 7.2.6), the analytical methods must be sufficient to detect contamination that is present in the samples at concentrations equal to the corresponding FALs. Analytical methods and minimum detectable concentrations (MDCs) for each COPC at CAU 124 are provided in Tables 3-4 and 3-5. The MDC is the lowest concentration of a chemical or radionuclide parameter that can be detected in a sample within an acceptable level of error. Due to changes in analytical methodology and changes in analytical laboratory contracts, information in Tables 3-4 and 3-5 that varies from corresponding information in the Quality Assurance Project Plan (QAPP) will supersede that information in the Industrial Sites QAPP (NNSA/NV, 2002a). 
Table 3-3

Targeted Analytes for CAU $124^{a}$

\begin{tabular}{||c|c|c|}
\hline Corrective Action Site & $\begin{array}{c}\text { Chemical } \\
\text { Targeted Analyte(s) }\end{array}$ & $\begin{array}{c}\text { Radiological } \\
\text { Targeted Analyte(s) }\end{array}$ \\
\hline \hline $08-02-01$ & None & None \\
\hline $15-02-01$ & None & None $^{\mathrm{b}}$ \\
\hline $16-02-03$ & None & None \\
\hline $16-02-04$ & TPH-DRO & None \\
\hline $16-99-04$ & TPH-DRO & None \\
\hline
\end{tabular}

If a COPC is detected at a concentration exceeding the action level it will be identified as a target analyte.

${ }^{\mathrm{b}}$ Iodine-131, although used at the EPA Farm, is not considered a target analyte due to its extremely short half-life of 8.01 days.

COPC = Contaminant of potential concern

$\mathrm{DRO}=$ Diesel-range organics

$\mathrm{TPH}=$ Total petroleum hydrocarbons

\subsection{Results of the DQO Analysis}

The following sections clearly define the results of the DQO process.

\subsubsection{Action Level Determination and Basis}

The PALs presented in this section are to be used for site screening purposes. They are not intended to be used as cleanup action levels or FALs. However, they are useful in screening out contaminants that are not present in sufficient concentrations to warrant further evaluation, therefore, streamlining the consideration of remedial alternatives. The risk-based corrective action (RBCA) process used to establish FALs is described in the Industrial Sites Project Establishment of Final Action Levels (NNSA/NSO, 2006a). This process conforms with Nevada Administrative Code (NAC) Section 445A.227 (NAC, 2006c), which lists the requirements for sites with soil contamination. For the evaluation of corrective actions, NAC Section 445A.22705 (NAC, 2006d), which requires the use of ASTM Method E 1739-95 (ASTM, 1995) to "conduct an evaluation of the site, based on the risk it poses to public health and the environment, to determine the necessary remediation standards (i.e., FALs) or to establish that corrective action is not necessary." 
Table 3-4

Analytical Requirements for Radionuclides for CAU 124

\begin{tabular}{|c|c|c|c|c|c|c|}
\hline $\begin{array}{c}\text { Parameterl } \\
\text { Analyte }\end{array}$ & Matrix & $\begin{array}{l}\text { Analytical } \\
\text { Method }\end{array}$ & $\mathrm{MDC}^{\mathrm{a}}$ & $P A L^{b, c}$ & $\begin{array}{c}\text { Laboratory } \\
\text { Precision (RPD) }\end{array}$ & $\begin{array}{c}\text { Percent } \\
\text { Recovery (\%R) }\end{array}$ \\
\hline \multirow{2}{*}{$\begin{array}{c}\text { Gamma } \\
\text { Spectroscopy }\end{array}$} & Aqueous & EPA 901.1 $1^{\mathrm{d}, \mathrm{e}}$ & $10 \mathrm{pCi} / \mathrm{L}^{\dagger}$ & $\overline{---}$ & \multirow{6}{*}{$\begin{array}{c}\text { Relative Percent } \\
\text { Difference (RPD) } \\
35 \% \%^{\mathrm{g}} \\
\text { Normalized } \\
\text { Difference } \\
-2<\mathrm{ND}<2^{\mathrm{h}}\end{array}$} & \multirow{6}{*}{$\begin{array}{c}\text { Laboratory Control } \\
\text { Sample Recovery } \\
80-120^{9} \text { Percent } \\
\text { Recovery }(\% \mathrm{R})\end{array}$} \\
\hline & Soil & HASL $300^{\mathrm{e}}$ & $0.5 \mathrm{pCi} / \mathrm{g}^{f}$ & $12.2 \mathrm{pCi} / \mathrm{g}^{\mathrm{i}}$ & & \\
\hline \multirow{2}{*}{ Tritium } & Aqueous & EPA 906.0 & $400 \mathrm{pCi} / L^{j}$ & $2 \mathrm{E}+4 \mathrm{pCi} / \mathrm{L}^{\mathrm{k}}$ & & \\
\hline & Soil & Lab Specific & $400 \mathrm{pCi} / \mathrm{L}$ & $4.0 \mathrm{E}+5 \mathrm{pCi} / \mathrm{L}^{\mathrm{j}}$ & & \\
\hline Gross Alpha & Aqueous & EPA 900.0 & $4.0 \mathrm{pCi} / \mathrm{L}$ & $15 \mathrm{pCi} / \mathrm{L}^{\mathrm{k}}$ & & \\
\hline Gross Beta & Aqueous & EPA 900.0 & $4.0 \mathrm{pCi} / \mathrm{L}$ & $50 \mathrm{pCi} / \mathrm{L}$ & & \\
\hline \multicolumn{7}{|c|}{ Other Radionuclides } \\
\hline \multirow{2}{*}{ Plutonium-238 } & Aqueous & HASL 300 & $0.1 \mathrm{pCi} / \mathrm{L}$ & $\overline{---}$ & \multirow{6}{*}{$\begin{array}{c}\text { Relative Percent } \\
\text { Difference (RPD) } \\
35 \%^{9}\end{array}$} & \multirow{6}{*}{$\begin{array}{c}\text { Laboratory Control } \\
\text { Sample Recovery } \\
80-120^{\mathrm{g}} \text { Percent } \\
\text { Recovery }(\% \mathrm{R})\end{array}$} \\
\hline & Soil & HASL 300 & $0.05 \mathrm{pCi} / \mathrm{g}$ & $13.0 \mathrm{pCi} / \mathrm{g}$ & & \\
\hline \multirow{2}{*}{ Plutonium-239/240 } & Aqueous & HASL 300 & $0.1 \mathrm{pCi} / \mathrm{L}$ & $\overline{--}$ & & \\
\hline & Soil & HASL 300 & $0.05 \mathrm{pCi} / \mathrm{g}$ & $12.7 \mathrm{pCi} / \mathrm{g}$ & & \\
\hline \multirow{2}{*}{ Strontium-90 } & Aqueous & HASL 300 & $1.0 \mathrm{pCi} / \mathrm{L}$ & -- & & \\
\hline & Soil & HASL 300 & $0.5 \mathrm{pCi} / \mathrm{g}$ & $830 \mathrm{pCi} / \mathrm{g}$ & & \\
\hline \multirow{2}{*}{ Uranium-234 } & Aqueous & HASL 300 & $0.1 \mathrm{pCi} / \mathrm{L}$ & -- & \multirow{6}{*}{$\begin{array}{c}\text { Normalized } \\
\text { Difference } \\
-2<N D<2^{\mathrm{h}}\end{array}$} & \multirow{6}{*}{$\begin{array}{c}\text { Chemical Yield } \\
30-105^{\mathrm{d}} \% \mathrm{R} \\
\text { (not applicable for } \\
\text { tritium) }\end{array}$} \\
\hline & Soil & HASL 300 & $0.05 \mathrm{pCi} / \mathrm{g}$ & $143 \mathrm{pCi} / \mathrm{g}$ & & \\
\hline \multirow{2}{*}{ Uranium-235 } & Aqueous & HASL 300 & $0.1 \mathrm{pCi} / \mathrm{L}$ & $\overline{--}$ & & \\
\hline & Soil & HASL 300 & $0.05 \mathrm{pCi} / \mathrm{g}$ & $17.6 \mathrm{pCi} / \mathrm{g}$ & & \\
\hline \multirow{2}{*}{ Uranium-238 } & Aqueous & HASL 300 & $0.1 \mathrm{pCi} / \mathrm{L}$ & -- & & \\
\hline & Soil & HASL 300 & $0.05 \mathrm{pCi} / \mathrm{g}$ & $105 \mathrm{pCi} / \mathrm{g}$ & & \\
\hline
\end{tabular}

${ }^{\mathrm{a}}$ The MDC is the lowest concentration of a radionuclide, if present in a sample, that can be detected with a 95 percent confidence level.

${ }^{b}$ The PALs for soil are based on the National Council for Radiation Protection and Measurement Report No. 129 Recommended Screening Limits for Contaminated Soil and Review of Factors Relevant to Site-Specific Studies (NCRP, 1999) scaled to 25-mrem/yr dose and the guidelines for residual concentration of radionuclides in DOE Order 5400.5 (DOE, 1993).

${ }^{\mathrm{C}} \mathrm{PALs}$ for liquids will be developed as needed.

${ }^{\mathrm{d}}$ Prescribed Procedures for Measurement of Radioactivity in Drinking Water, EPA-600/4-80-32 (EPA, 1980).

${ }^{\mathrm{e}}$ The Procedures Manual of the Environmental Measurements Laboratory, HASL-300 (DOE, 1997).

${ }^{f} M D C s$ vary depending on the presence of other gamma-emitting radionuclides in the sample and are relative to the MDC for cesium-137.

${ }^{9}$ Contract Laboratory Program Statement of Work for Inorganic Analysis (EPA, 1988, 1994, and 1995).

${ }^{\mathrm{h}} \mathrm{ND}$ is not RPD, it is another measure of precision used to evaluate duplicate analyses. The ND is calculated as the difference between two results divided by the square root, of the sum of the squares, of their total propagated uncertainties. Evaluation of Radiochemical Data Usability (Paar and Porterfield, 1997).

${ }^{\mathrm{h}}$ Contract Laboratory Program Statement of Work for Inorganic Analysis (EPA, 1988, 1994, and 1995).

iPAL for cesium-137. Other gamma-emitting radionuclides have other PALs.

$\mathrm{j}$ Units of $\mathrm{pCi} / \mathrm{L}$ will be reported by the analytical laboratory based on the activity of the tritium in the soil moisture. The PAL for tritium in soil is based on the Project limit of 400,000 pCi/L for discharge of water containing tritium to an infiltration basin/area (NNSA/NV, 2002b).

${ }^{\mathrm{k}}$ State of Nevada Water Pollution Control General Permit, GNEV93001 (NDEP, 1999).

MDC = Minimum detectable concentration

$\mathrm{mrem} / \mathrm{yr}=$ Millirem per year

$\mathrm{ND}=$ Normalized difference

$\mathrm{PAL}=$ Preliminary action level

$\mathrm{pCi} / \mathrm{g}=$ Picocuries per gram

$\mathrm{pCi} / \mathrm{L}=$ Picocuries per liter

UGTA = Underground Test Area 
Table 3-5

Analytical Requirements for Chemical COPCs for CAU 124

(Page 1 of 2)

\begin{tabular}{|c|c|c|c|c|c|}
\hline ParameterlAnalyte & $\begin{array}{l}\text { Medium } \\
\text { or } \\
\text { Matrix }\end{array}$ & $\begin{array}{l}\text { Analytical } \\
\text { Method }\end{array}$ & $\begin{array}{c}\text { Minimum } \\
\text { Detectable } \\
\text { Concentration } \\
\text { (MDC) }\end{array}$ & $\begin{array}{l}\text { Laboratory } \\
\text { Precision } \\
\text { (RPD) }\end{array}$ & $\begin{array}{c}\text { Percent } \\
\text { Recovery } \\
\text { (\%R) }\end{array}$ \\
\hline \multicolumn{6}{|c|}{ Organics } \\
\hline \multirow{2}{*}{$\begin{array}{l}\text { Total Volatile Organic } \\
\text { Compounds }\end{array}$} & Aqueous & \multirow{2}{*}{$8260 B^{a}$} & \multirow{2}{*}{$\begin{array}{l}\text { Parameter-specific } \\
\text { MDCs }^{\mathrm{b}}\end{array}$} & \multirow{2}{*}{ Lab-specific $^{c}$} & \multirow{2}{*}{ Lab-specific $^{c}$} \\
\hline & Soil & & & & \\
\hline \multirow{2}{*}{$\begin{array}{l}\text { Total Semivolatile Organic } \\
\text { Compounds }\end{array}$} & Aqueous & \multirow{2}{*}{$8270 C^{a}$} & \multirow{2}{*}{$\begin{array}{l}\text { Parameter-specific } \\
\text { MDCs }^{b}\end{array}$} & \multirow{2}{*}{ Lab-specific $^{c}$} & \multirow{2}{*}{ Lab-specific $^{c}$} \\
\hline & Soil & & & & \\
\hline \multirow{2}{*}{ Polychlorinated Biphenyls } & Aqueous & \multirow{2}{*}{$8082^{a}$} & \multirow{2}{*}{$\begin{array}{l}\text { Parameter-specific } \\
\text { MDCs }^{\text {b }}\end{array}$} & \multirow{2}{*}{ Lab-specific $^{c}$} & \multirow{2}{*}{ Lab-specific ${ }^{c}$} \\
\hline & Soil & & & & \\
\hline \multirow{2}{*}{$\begin{array}{l}\text { Total Petroleum Hydrocarbons- } \\
\text { Gasoline-Range Organics }\end{array}$} & Aqueous & \multirow{2}{*}{$\begin{array}{l}\text { 8015B } \\
\text { modified }^{\mathrm{a}}\end{array}$} & \multirow{8}{*}{$\begin{array}{l}\text { Parameter-specific } \\
\text { MDCs }^{\mathrm{d}}\end{array}$} & \multirow{8}{*}{ Lab-specific $^{c}$} & \multirow{8}{*}{ Lab-specific $^{c}$} \\
\hline & Soil & & & & \\
\hline \multirow{2}{*}{$\begin{array}{l}\text { Total Petroleum Hydrocarbons- } \\
\text { Diesel-Range Organics }\end{array}$} & Aqueous & \multirow{2}{*}{$\begin{array}{l}\text { 8015B } \\
\text { modified }^{\mathrm{a}}\end{array}$} & & & \\
\hline & Soil & & & & \\
\hline \multirow{2}{*}{ Pesticides } & Aqueous & \multirow{2}{*}{$8081 A^{a}$} & & & \\
\hline & Soil & & & & \\
\hline \multirow{2}{*}{ Herbicides } & Aqueous & \multirow{2}{*}{$8151 A^{a}$} & & & \\
\hline & Soil & & & & \\
\hline \multicolumn{6}{|c|}{ Total RCRA Metals } \\
\hline \multirow{2}{*}{ Arsenic } & Aqueous & $6010 B^{a}$ & $0.01 \mathrm{mg} / \mathrm{L}^{\mathrm{d}}$ & \multirow{6}{*}{$\begin{array}{l}\text { RPD }^{d} \\
35 \% \text { for solid } \\
20 \% \text { for } \\
\text { aqueous or } \\
+/- \text { Absolute } \\
\text { difference } 2 x \\
\text { RL for solid } \\
\text { or } 1 \times \text { RL for } \\
\text { aqueous }\end{array}$} & \multirow{6}{*}{$\begin{array}{c}\text { Matrix Spike } \\
\text { Recovery } \\
\text { at } \\
75-125^{d}\end{array}$} \\
\hline & Soil & $6010 B^{a}$ & $1 \mathrm{mg} / \mathrm{kg}^{\mathrm{d}}$ & & \\
\hline \multirow{2}{*}{ Barium } & Aqueous & $6010 B^{a}$ & $0.20 \mathrm{mg} / \mathrm{L}^{\mathrm{d}}$ & & \\
\hline & Soil & $6010 B^{a}$ & $20 \mathrm{mg} / \mathrm{kg}^{\mathrm{d}}$ & & \\
\hline \multirow[b]{2}{*}{ Cadmium } & Aqueous & $6010 B^{a}$ & $0.005 \mathrm{mg} / \mathrm{L}^{\mathrm{d}}$ & & \\
\hline & Soil & $6010 B^{a}$ & $0.5 \mathrm{mg} / \mathrm{L}^{\mathrm{d}}$ & & \\
\hline
\end{tabular}


Table 3-5

Analytical Requirements for Chemical COPCs for CAU 124

(Page 2 of 2)

\begin{tabular}{|c|c|c|c|c|c|}
\hline Parameter/Analyte & $\begin{array}{c}\text { Medium } \\
\text { or } \\
\text { Matrix }\end{array}$ & $\begin{array}{l}\text { Analytical } \\
\text { Method }\end{array}$ & $\begin{array}{c}\text { Minimum } \\
\text { Detectable } \\
\text { Concentration } \\
\text { (MDC) }\end{array}$ & $\begin{array}{l}\text { Laboratory } \\
\text { Precision } \\
\text { (RPD) }\end{array}$ & $\begin{array}{l}\text { Percent } \\
\text { Recovery } \\
(\% \mathrm{R})\end{array}$ \\
\hline \multirow{2}{*}{ Chromium } & Aqueous & $6010 B^{a}$ & $0.01 \mathrm{mg} / \mathrm{L}^{\mathrm{d}}$ & \multirow{10}{*}{$\begin{array}{l}\text { RPD }^{d} \\
35 \% \text { for solid } \\
20 \% \text { for } \\
\text { aqueous or } \\
+/- \text { Absolute } \\
\text { difference } 2 x \\
\text { RL for solid } \\
\text { or } 1 x \text { RL for } \\
\text { aqueous }\end{array}$} & \multirow{5}{*}{$\begin{array}{c}\text { Matrix Spike } \\
\text { Recovery } \\
\text { at } \\
75-12 d^{g}\end{array}$} \\
\hline & Soil & $6010 B^{a}$ & $1 \mathrm{mg} / \mathrm{kg}^{\mathrm{d}}$ & & \\
\hline \multirow{2}{*}{ Lead } & Aqueous & $6010 B^{a}$ & $0.003 \mathrm{mg} / \mathrm{L}^{\mathrm{d}}$ & & \\
\hline & Soil & $6010 B^{a}$ & $0.3 \mathrm{mg} / \mathrm{kg}^{\mathrm{d}}$ & & \\
\hline \multirow{2}{*}{ Mercury } & Aqueous & $7470 A^{a}$ & $0.0002 \mathrm{mg} / \mathrm{L}^{\mathrm{d}}$ & & \\
\hline & Soil & $7471 A^{a}$ & $0.1 \mathrm{mg} / \mathrm{kg}^{\mathrm{d}}$ & & \multirow{5}{*}{$\begin{array}{l}\text { Laboratory } \\
\text { Control Sample } \\
\text { Recovery } \\
\text { at } \\
80-120^{\text {d }}\end{array}$} \\
\hline \multirow{2}{*}{ Selenium } & Aqueous & $6010 \mathrm{~B}^{\mathrm{a}}$ & $0.005 \mathrm{mg} / \mathrm{L}^{\mathrm{d}}$ & & \\
\hline & Soil & $6010 B^{a}$ & $0.5 \mathrm{mg} / \mathrm{kg}^{\mathrm{d}}$ & & \\
\hline \multirow{2}{*}{ Silver } & Aqueous & $6010 \mathrm{~B}^{\mathrm{a}}$ & $0.01 \mathrm{mg} / \mathrm{L}^{\mathrm{d}}$ & & \\
\hline & Soil & $6010 B^{a}$ & $1 \mathrm{mg} / \mathrm{kg}^{\mathrm{d}}$ & & \\
\hline
\end{tabular}

See Table 3-4 for the analytical requirements for radionuclides.

${ }^{a}$ Test Methods for Evaluating Solid Waste Physical/Chemical Methods, 3rd Edition, Parts 1-4, (SW-846) CD-ROM, Washington, DC (EPA,1996).

${ }^{b}$ MDCs are known as Estimated Quantitation Limit in SW-846 (EPA, 1996).

${ }^{\mathrm{C}} \mathrm{RPD}$ and \%R Performance Criteria are developed and generated in-house by the laboratory according to approved laboratory procedures.

dindustrial Sites Quality Assurance Project Plan (NNSA/NV, 2002a).

$\mathrm{MDC}=$ Minimum detectable concentration

$\mathrm{mg} / \mathrm{L}=$ Milligrams per liter

$\mathrm{mg} / \mathrm{kg}=$ Milligrams per kilogram

RCRA = Resource Conservation and Recovery Act

$\mathrm{RL}=$ Reporting limit

$\mathrm{RPD}=$ Relative percent difference 
This RBCA process, summarized in Figure 3-1, defines three tiers (or levels) of evaluation involving increasingly sophisticated analyses:

- Tier 1 evaluation - Sample results from source areas (highest concentrations) are compared to action levels based on generic (non-site-specific) conditions (i.e., the PALs established in the Corrective Action Investigation Plan). The FALs may then be established as the Tier 1 action levels or the FALs may be calculated using a Tier 2 evaluation.

- $\quad$ Tier 2 evaluation - Conducted by calculating Tier 2 site-specific target levels (SSTLs) using site-specific information as inputs to the same or similar methodology used to calculate Tier 1 action levels. The Tier 2 SSTLs are then compared to individual sample results from reasonable points of exposure (as opposed to the source areas as is done in Tier 1) on a point-by-point basis. Total petroleum hydrocarbons (TPH) concentration totals will not be used for risk-based decisions under Tier 2 or Tier 3. Rather, the individual chemicals of concern will be compared to the SSTLs.

- Tier 3 evaluation - Conducted by calculating Tier 3 SSTLs on the basis of more sophisticated risk analyses using methodologies described in Method E1739-95 that consider site-, pathway-, and receptor-specific parameters.

Evaluation of DQO decisions will be based on conditions at the site following completion of corrective actions. Corrective actions conducted will be reported in the CR.

The FALs (along with the basis for selection) will be defined in the CR, where they will be compared to laboratory results in the evaluation of site closure.

\subsubsection{Chemical PALs}

Except as noted herein, the chemical PALs are defined as the Region 9 PRGs for chemical contaminants in industrial soils (EPA, 2004). Background concentrations for RCRA metals will be used instead of PRGs when natural background concentrations exceed the PRG, as is often the case with arsenic on the NTS. Background is considered the mean plus two standard deviations for sediment samples collected by the Nevada Bureau of Mines and Geology throughout the Nevada Test and Training Range (formerly the Nellis Air Force Range) (NBMG, 1998; Moore, 1999). For detected chemical COPCs without established PRGs, the protocol used by the EPA Region 9 in establishing PRGs (or similar) will be used to establish PALs. If used, this process will be documented in the CR. 


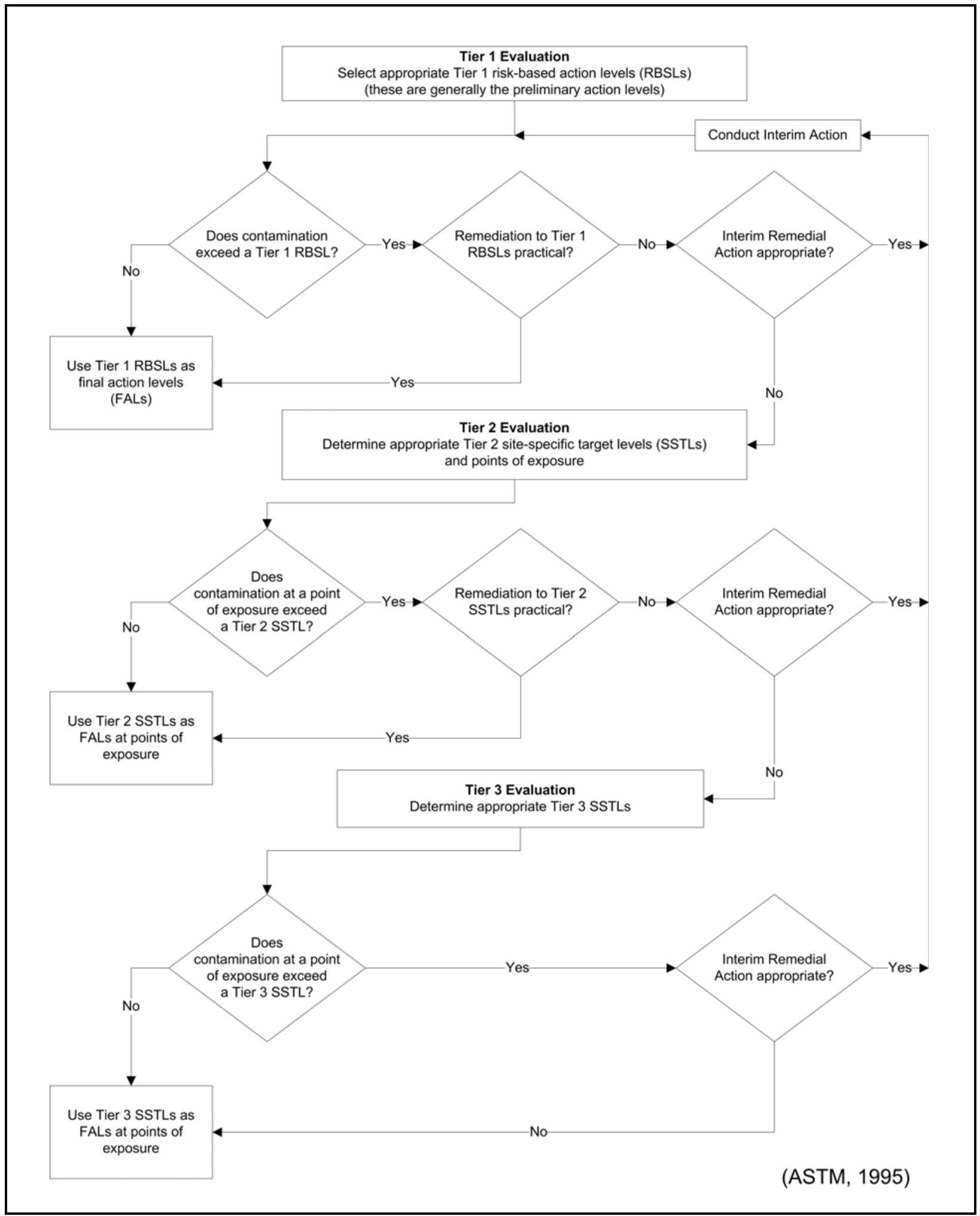

Figure 3-1

Risk-Based Corrective Action Decision Process 


\subsubsection{Total Petroleum Hydrocarbons PALs}

The PAL for TPH is 100 parts per million (ppm) as listed in NAC 445A.2272 (NAC, 2006e).

\subsubsection{Radionuclide PALs}

The PALs for radiological contaminants (other than tritium) are based on the National Council on Radiation Protection and Measurement (NCRP) Report No. 129 recommended screening limits for construction, commercial, industrial land-use scenarios (NCRP, 1999) using a 25-millirem-per-year (mrem/yr) dose constraint (Murphy, 2004) and the generic guidelines for residual concentration of radionuclides in DOE Order 5400.5 (DOE, 1993). These PALs are based on the construction, commercial, and industrial land-use scenario provided in the guidance, and are appropriate for the NTS based on future land uses presented in Section B.2.2.6.

The PAL for tritium is based on the Underground Test Area (UGTA) Project limit of 400,000 picocuries per liter (pCi/L) for discharge of water containing tritium (NNSA/NV, 2002b). The activity of tritium in the soil moisture of soil samples will be reported in units of $\mathrm{pCi} / \mathrm{L}$ for comparison to this PAL.

Materials/structures that have the potential for surface contamination may be surveyed for unrestricted release as given in the NV/YMP Radiological Control Manual (NNSA/NSO, 2004).

\subsubsection{Hypothesis Test}

The baseline condition (i.e., null hypothesis) and alternative condition are:

- Baseline condition - Closure objectives have not been met.

- Alternative condition - Closure objectives have been met.

Sufficient evidence to reject the null hypothesis is:

- The identification of the lateral and vertical extent of COC contamination in media, if present.

- Sufficient information to properly dispose of investigation-derived waste (IDW) and remediation waste. 


\subsubsection{Statistical Model}

A judgmental sampling design will be implemented to select sample locations and evaluate DQO decisions for CAU 124 CASs. The sampling design will assume that the data are not normally distributed and that the statistical test will be to compare individual results to fixed threshold values (i.e., FALs).

\subsubsection{Design Description/Option}

The judgmental sampling approach will be to collect samples from the locations most likely to contain COCs, if present within each CAS.

Sample locations will be selected to satisfy the DQI of representativeness in that samples collected from selected locations will best represent the populations of interest as defined in Section B.5.1. To meet this criterion for judgmentally sampled sites, a biased sampling strategy will be used for Decision I samples to target areas with the highest potential for contamination, if it is present in the CAS. Sample locations will be determined based on process knowledge, previously acquired data, or the field-screening and biasing factors listed in Section B.4.2.1. If biasing factors are present in soils below locations where Decision I samples were removed, additional Decision I soil samples will be collected at depth intervals selected by the Site Supervisor (SS) based on biasing factors to a depth where the biasing factors are no longer present. As biasing factors have not been identified at the Plots A and B of CAS 15-02-01, randomly selected judgmental sample locations have been determined using the Visual Sample Plan (VSP) software (PNNL, 2005). The SS has the discretion to modify the judgmental sample locations, but only if the modified locations meet the decision needs and criteria stipulated in this DQO. If a sample cannot be collected from a predetermined location, the SS will establish an alternate at the nearest location where a sample can be obtained.

Because individual sample results, rather than an average concentration, will be used to compare to FALs at the CASs, statistical methods to generate site characteristics will not be used. Adequate representativeness of the entire target population may not be a requirement to developing a sampling design. If good prior information is available on the target site of interest, then the sampling may be designed to collect samples only from areas known to have the highest concentration levels on the target site. If the observed concentrations from these samples are below the action level, then a 
decision can be made that the site contains safe levels of the contaminant without the samples being truly representative of the entire area (EPA, 2006).

\subsubsection{Conceptual Site Model and Drawing}

The CSM describes the most probable scenario for current conditions at each site and defines the assumptions that are the basis for identifying the future land use, contaminant sources, release mechanisms, migration pathways, exposure points, and exposure routes. The CSM is also used to support appropriate sampling strategies and data collection methods. The CSM has been developed for CAU 124 using information from the physical setting, potential contaminant sources, release information, historical background information, knowledge from similar sites, and physical and chemical properties of the potentially affected media and COPCs. Figure 3-2 depicts a graphical representation of the conceptual pathways to receptors from CAU 124 sources. Figure 3-3 depicts a tabular representation of the CSM. If evidence of contamination is inconsistent with the presented CSM identified during investigation activities, the situation will be reviewed, the CSM revised, the DQOs re-assessed, and a recommendation made as to how to proceed. In such cases, participants in the DQO process will be notified and given the opportunity to comment on and/or concur with the recommendation. A detailed discussion of the CSM is presented in Appendix B. 


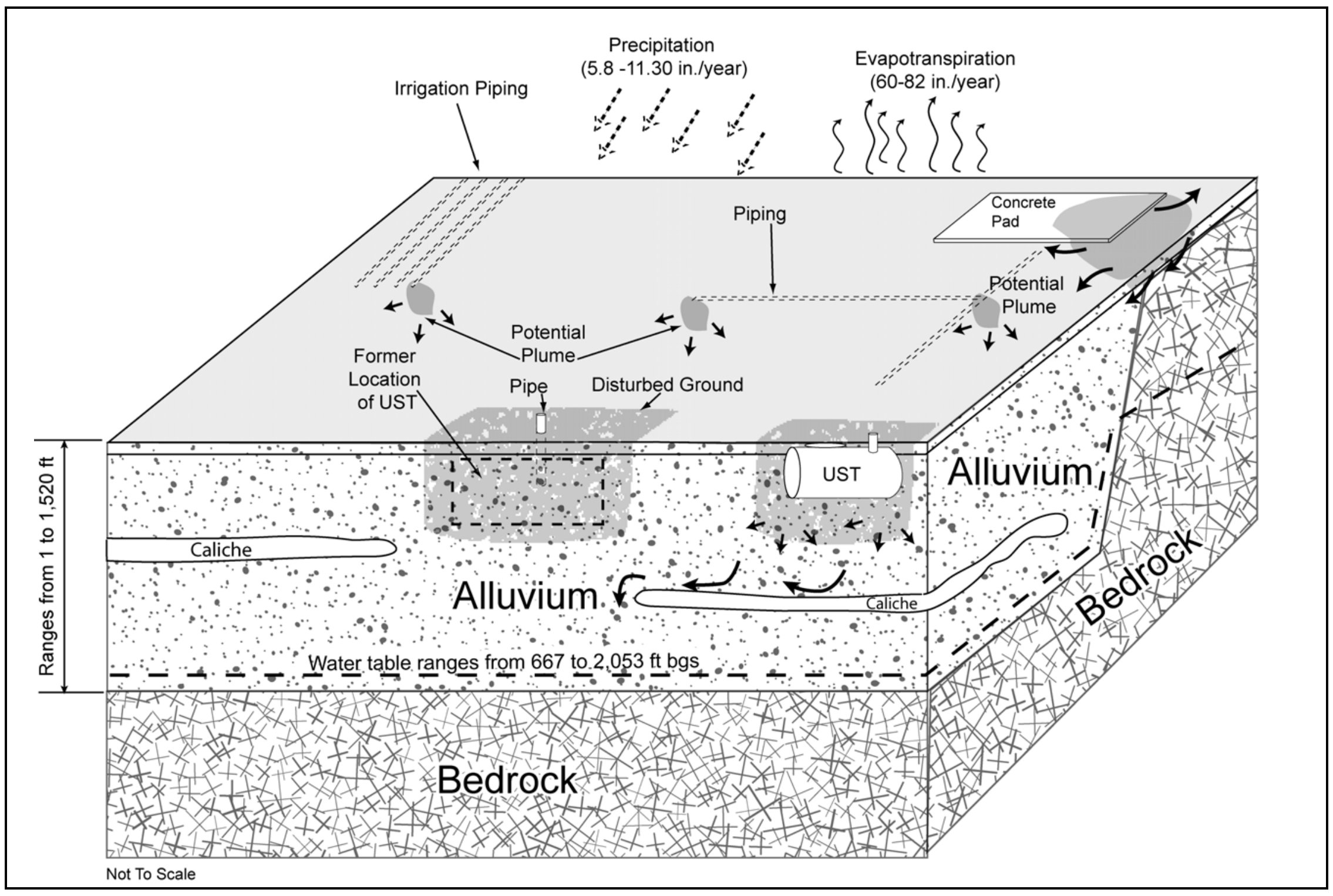

Figure 3-2

Conceptual Site Model for CAU 124 


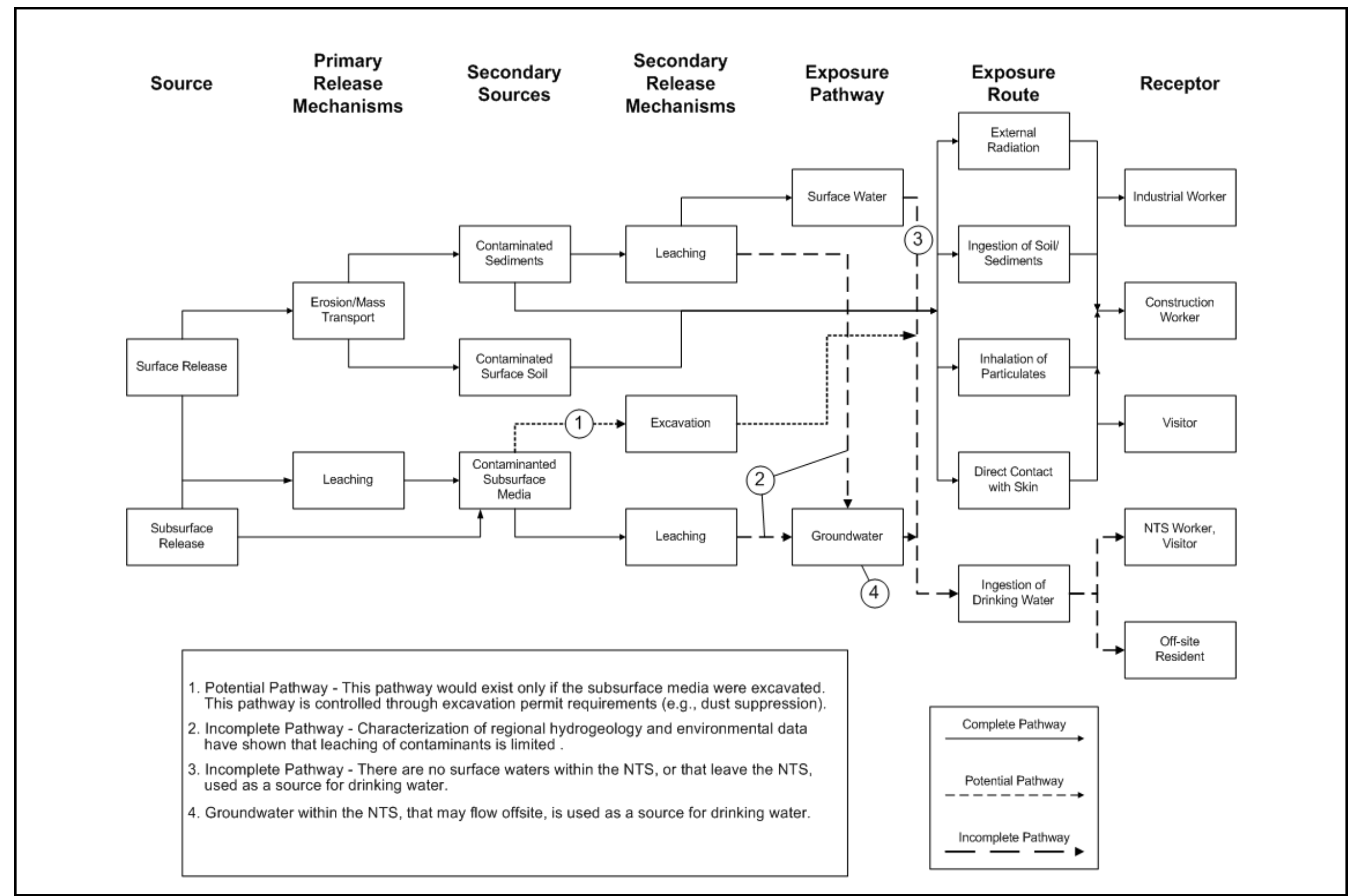

Figure 3-3

Conceptual Site Model Diagram for CAU 124 


\subsection{Field Activities and Closure Objectives}

This section of the SAFER Plan provides a description of the CAU 124 field activities and closure objectives, which are to determine if COCs exist. If remediation is determined to be feasible, then the extent of COCs will be determined so that a closure alternative may be implemented. Sampling activities will be conducted in compliance with the Industrial Sites QAPP (NNSA/NV, 2002b) and other applicable, approved procedures and instructions.

\subsection{Contaminants of Potential Concern}

The CAU 124 COPCs are defined as the list of constituents represented by the analytical methods identified in Table 3-1 for Decision I environmental samples taken at each CAS. The constituents reported for each analytical method are listed in Table 3-2.

The list of COPCs is intended to encompass all of the contaminants that could potentially be present at each CAS. These COPCs were identified during the planning process through the review of site history, process knowledge, personal interviews, past investigation efforts (where available), and inferred activities associated with the CASs. Contaminants detected at other similar or other NTS sites were also included in the COPC list to reduce the uncertainty about potential contamination at the CASs, because complete information regarding activities performed at the CAU 124 sites is not available.

\subsection{Remediation}

The DQOs developed for CAU 124 identified data gaps that require additional data collection before identifying and implementing the preferred closure alternative for each CAS. A decision point approach, based on the DQOs, for making remediation decisions is summarized in Figure 1-2. The presence of contamination, if any, is assumed to be confined to the spatial boundaries of the sites as defined in the DQO process and CSM.

If COCs are identified within a CAS based on the initial investigation results, that CAS will be further assessed before implementing closure activities. If COPCs are not present at concentrations exceeding FALs, no further action will be recommended for the CAS. The objective of the initial 
investigation strategy is to determine if COCs are present and confirm the anticipated corrective actions are appropriate. Laboratory analytical results will be used to confirm the presence or absence of COCs.

If COCs are present, or it is decided that COCs may be present based on the presence of biasing factors, a corrective action of removal for disposal may be implemented and additional verification samples taken from biased locations within the excavation.

\subsection{Verification}

Verification sampling of subsurface soil will be required at CASs where soil excavation and removal are part of the closure decision (e.g., close in place or clean closure alternative). The number and location of verification samples will be determined in the field. The information necessary to satisfy the closure criteria will be generated for each CAU 124 CAS by collecting and analyzing samples generated during a field investigation. If a COC is present and removal of the COC is feasible, verification sampling of remaining environmental media may be required. The verification samples will be collected from the approximate center of the bottom of the excavation below the stained area and at lateral boundaries. The final locations and numbers of verification samples to be collected will be determined in the field based on the presence of biasing factors, as listed in Section B.4.2.1; the size of the excavation, site conditions, and professional judgment by the SS. Verification sample locations must meet the DQO decision needs and criteria stipulated in Appendix B. The number and location of verification samples will be justified in the CR.

If a COC is present and removal is not feasible, information on the extent of COC contamination will be obtained by collecting step-out (Decision II) samples. Decision II sampling will consist of further defining the extent of contamination where COCs have been confirmed. Step-out (Decision II) sampling locations at each CAS will be selected based on the CSM, biasing factors, field-screening results (FSRs), existing data, and the outer boundary sample locations where COCs were detected. In general, step-out sample locations will be arranged in a triangular pattern around areas containing a COC at distances based on site conditions, COC concentrations, process knowledge, and other biasing factors. If COCs extend beyond step-out locations, additional Decision II samples will be collected from locations further from the source. If a spatial boundary is reached, the CSM is shown 
to be inadequate, or the SS determines that extent sampling needs to be re-evaluated, work will be suspended temporarily, NDEP notified, and the investigation strategy re-evaluated.

The closure objectives will have been met and the CAS will be proposed for closure if the following conditions are true:

- A COC is not present at a CAS or a COC is present, and the extent of each COC has been defined.

- Information is sufficient to characterize remediation waste and IDW for disposal.

Because this SAFER Plan only addresses contamination originating from the CAU, it may be necessary to distinguish overlapping contamination originating from other sources. For example, widespread surface radiological contamination originating from atmospheric tests will not be addressed in the CAU 124 investigation. To determine whether contamination is from the CAU or from other sources, soil samples may be collected from background locations at selected CASs.

Modifications to the investigation strategy may be required should unexpected field conditions be encountered at any CAS. Significant modifications shall be justified and documented in a Record of Technical Change before implementation. If an unexpected condition indicates that conditions are significantly different than the corresponding CSM, the activity will be rescoped and the decision-makers notified. Field activities at CAU 124 include site preparation, sample location selection, sample collection activities, waste characterization, photo-documentation, and collection of geocoordinates.

Table 4-1 summarizes the sampling approach to achieve closure objectives for each CAU 124 CAS. 
Table 4-1

Sampling Approach for CAU 124 CASs

(Page 1 of 2)

\begin{tabular}{|c|c|c|c|c|c|c|c|}
\hline $\begin{array}{l}\text { Corrective } \\
\text { Action } \\
\text { Site }\end{array}$ & $\begin{array}{l}\text { Total } \\
\text { Number } \\
\text { of } \\
\text { Samples }\end{array}$ & $\begin{array}{l}\text { Sample } \\
\text { Location }\end{array}$ & $\begin{array}{l}\text { Minimum } \\
\text { Number } \\
\text { of } \\
\text { Sample } \\
\text { Locations }\end{array}$ & $\begin{array}{l}\text { Minimum } \\
\text { Number } \\
\text { of Samples } \\
\text { per Location }\end{array}$ & $\begin{array}{c}\text { Sample } \\
\text { Collection } \\
\text { Requirements }^{\mathrm{a}, \mathrm{b}, \mathrm{c}, \mathrm{d}}\end{array}$ & $\begin{array}{l}\text { Samples } \\
\text { Submitted } \\
\text { for Analysis }\end{array}$ & $\begin{array}{l}\text { Sampling } \\
\text { Method } \\
\text { Alternatives }\end{array}$ \\
\hline \multirow{6}{*}{$15-02-01$} & 6 & $\begin{array}{l}\text { Outside CAS } \\
\text { Boundary }\end{array}$ & 6 & 1 & $\begin{array}{l}6 \text { random locations outside CAS } \\
\text { boundary }\end{array}$ & \multirow{6}{*}{$\begin{array}{l}\text { All soil } \\
\text { samples; } \\
\text { all concrete } \\
\text { samples }\end{array}$} & \multirow{6}{*}{$\begin{array}{c}\text {-Hand sampling } \\
\text {-Swipe Sampling } \\
\text {-Scabbling } \\
\text { (concrete) }\end{array}$} \\
\hline & 8 & Plots $A$ and $B$ & 4 each plot & 1 & $\begin{array}{l}\text { Sample collection points determined } \\
\text { by random grid pattern }\end{array}$ & & \\
\hline & 12 & $\begin{array}{l}\text { Plot } A \text { and Plot } B \\
\text { Irrigation Lines }\end{array}$ & 2 each plot & 3 & $\begin{array}{l}1 \text { swipe from proximal end and } \\
\text { distal end of irrigation line along with } \\
1 \text { surface and } 1 \text { subsurface soil } \\
\text { sample where swipe sample taken } \\
\text { in each plot }\end{array}$ & & \\
\hline & 8 & \multirow[t]{2}{*}{ Concrete Pads } & 8 & 1 & $\begin{array}{l}\text { Surface sample at the edge of each } \\
\text { side of concrete pads }\end{array}$ & & \\
\hline & TBD & & TBD & 1 & Biasing factors of concrete pads & & \\
\hline & 4 & Reservoir & 4 & 1 & $\begin{array}{l}\text { Surface or shallow subsurface } \\
\text { sample }\end{array}$ & & \\
\hline $\begin{array}{l}08-02-01 \\
16-02-03 \\
16-99-04\end{array}$ & 1 & $\begin{array}{l}\text { Surface adjacent to } \\
\text { exposed pipe(s) }\end{array}$ & 1 & 1 & Surface sample & All soil samples & -Hand sampling \\
\hline $16-99-04$ & 4 & Concrete Pad & 4 & 1 & $\begin{array}{l}\text { Surface sample at the edge of each } \\
\text { side of concrete pad }\end{array}$ & All soil samples & -Hand sampling \\
\hline $\begin{array}{l}08-02-01 \\
16-02-03 \\
16-99-04\end{array}$ & TBD & $\begin{array}{l}\text { Within footprint of } \\
\text { excavation }\end{array}$ & 1 & 1 & $\begin{array}{l}\text { UST- contents of each phase; } 1 \text { soil } \\
\text { sample from inlet; } 1 \text { soil sample } \\
\text { from outlet; } 2 \text { soil samples from } \\
\text { under base; biasing factors } \\
\text { No UST- } 1 \text { soil sample from } \\
\text { disturbed/undisturbed soilinterface; } \\
\text { If interface undetermined } 1 \text { soil } \\
\text { sample from } \sim 12 \mathrm{ft} \text { and } 1 \text { soil } \\
\text { sample from } \sim 15 \mathrm{ft} \text {; and biasing } \\
\text { factors }\end{array}$ & All soil samples & $\begin{array}{c}\text {-Hand sampling } \\
\text {-Backhoe } \\
\text { excavation }\end{array}$ \\
\hline
\end{tabular}


Table 4-1

Sampling Approach for CAU 124 CASs

(Page 2 of 2)

\begin{tabular}{|c|c|c|c|c|c|c|c|}
\hline $\begin{array}{l}\text { Corrective } \\
\text { Action } \\
\text { Site }\end{array}$ & $\begin{array}{l}\text { Total } \\
\text { Number } \\
\text { of } \\
\text { Samples }\end{array}$ & $\begin{array}{l}\text { Sample } \\
\text { Location }\end{array}$ & $\begin{array}{l}\text { Minimum } \\
\text { Number } \\
\text { of } \\
\text { Sample } \\
\text { Locations }\end{array}$ & $\begin{array}{l}\text { Minimum } \\
\text { Number } \\
\text { of Samples } \\
\text { per Location }\end{array}$ & $\begin{array}{c}\text { Sample } \\
\text { Collection } \\
\text { Requirements }^{\mathrm{a}, \mathrm{b}, \mathrm{c}, \mathrm{d}}\end{array}$ & $\begin{array}{l}\text { Samples } \\
\text { Submitted } \\
\text { for Analysis }\end{array}$ & $\begin{array}{l}\text { Sampling } \\
\text { Method } \\
\text { Alternatives }\end{array}$ \\
\hline $16-02-04$ & 4 & Concrete pad & 4 & 1 & $\begin{array}{l}\text { Surface sample at the edge of each } \\
\text { side of concrete pad; } 1 \text { side to } \\
\text { coordinate with metal pipe at edge } \\
\text { of concrete pad }\end{array}$ & All soil samples & -Hand sampling \\
\hline $16-02-04$ & TBD & $\begin{array}{l}\text { Soil sample from end } \\
\text { points where } \\
\text { connections would } \\
\text { have been made; } \\
\text { biasing factors }\end{array}$ & TBD & 1 & $\begin{array}{l}\text { Surface or shallow subsurface } \\
\text { sample; if FSRs > FSLs, continue } \\
\text { collecting samples until FSRs < } \\
\text { FSLs in two consecutive samples }\end{array}$ & All soil samples & $\begin{array}{l}\text {-Hand sampling } \\
\text {-Backhoe } \\
\text { excavation }\end{array}$ \\
\hline
\end{tabular}

${ }^{\mathrm{a}}$ For worker protection, field screening will not be conducted if a strong odor and/or visual evidence suggests contamination is present

${ }^{b}$ Additional samples may be collected at the discretion of the SS.

'Additional samples may be submitted at the discretion of the SS

${ }^{\mathrm{d} S u r f a c e}$ sample interval is 0 to 6 inches. Shallow subsurface sample interval is 6 inches to $5 \mathrm{ft}$. Subsurface sample interval is greater than $5 \mathrm{ft}$.

FSL = Field-screening level

FSR $=$ Field-screening result

$\mathrm{ft}=$ Foot

$\mathrm{N} / \mathrm{A}=$ Not applicable

SS $=$ Site Supervisor

$\mathrm{TBD}=$ To be determined

UST = Underground storage tank 


\subsection{Closure}

At a minimum, the following activities have been identified for closure of these CASs. The decision logic behind the activities is provided in Figure 1-2:

- Identified USTs will be closed in accordance with NAC 459.9972, "UST Closure" and the contents will be removed (NAC, 2005).

- Any USTs and their contents, if any, will be disposed of in accordance with Section 6.0 of this SAFER Plan.

- If no COCs are detected, the CAS will be closed with no further action.

- Exposed piping will be sealed as a best management practice.

- If COCs are present and removal of the COCs is not feasible, closure in place will be the preferred corrective action alternative. The appropriate use restrictions will be implemented and documented in the CR.

- If COCs are present and removal is feasible, clean closure will be the preferred corrective action alternative. The material to be remediated will be removed and disposed as waste, and verification samples will be collected from the remaining soil. Verification analytical results will be documented in the CR.

After completion of the CAI and waste management activities, the following actions will be implemented before closure of the site Real Estate/Operating Permit:

- Removal of equipment, wastes, debris, and materials associated with the CAI

- Removal of signage and fencing (unless part of a corrective action)

- Grading of site to pre-investigation condition (unless changed condition is necessary under a corrective action)

- Site will be inspected and certified that restoration activities have been completed 


\subsection{Duration}

Table 4-2 is a tentative duration (in calendar days) for SAFER activities:

Table 4-2

SAFER Field Activities

\begin{tabular}{|c|c|}
\hline Duration (days) & Activity \\
\hline \hline 20 & Site Preparation \\
\hline 3 & Site Mobilization \\
\hline 30 & Field Work \\
\hline 28 & Sample Analysis \\
\hline 42 & Data Validation and Assessment \\
\hline 195 & Closure Report \\
\hline 180 & Waste Management and Disposition \\
\hline
\end{tabular}




\subsection{Reports and Records Availability}

Reports generated during ongoing field activities will be provided to NDEP upon request.

Historic information and documents referenced in this plan are retained in the NNSA/NSO project files in Las Vegas, Nevada, and can be obtained through written request to the NNSA/NSO Federal Sub-Project Director. This document is available in the DOE public reading rooms in Las Vegas and Carson City, Nevada, or by contacting the NNSA/NSO Federal Sub-Project Director. The NDEP maintains the official Administrative Record for all activities conducted under the auspices of the FFACO. 


\subsection{Investigation/Remediation Waste Management}

Management of IDW will be based on regulatory requirements, field observations, process knowledge, and laboratory results from CAU 124 investigation samples.

Disposable sampling equipment, personal protective equipment (PPE), and rinsate are considered potentially contaminated waste only by virtue of contact with potentially contaminated media (e.g., soil) or potentially contaminated debris (e.g., construction materials). Therefore, sampling and analysis of IDW, separate from analyses of site investigation samples, may not be necessary for all IDW. However, if associated investigation samples are found to contain contaminants above regulatory levels, conservative estimates of total waste contaminant concentrations may be made based on the mass of the waste, amount of contaminated media contained in the waste, and maximum concentration of contamination found in the media. Direct samples of IDW may also be taken to support waste characterization.

Sanitary, hazardous, radioactive, and/or mixed waste, if generated, will be managed and disposed of in accordance with applicable DOE orders, U.S. Department of Transportation (DOT) regulations, state and federal waste regulations, and agreements and permits between DOE and NDEP.

\subsection{Waste Minimization}

Investigation activities are planned to minimize IDW generation. This will be accomplished by incorporating the use of process knowledge, visual examination, and/or radiological survey and swipe results. When possible, disturbed media (such as soil removed during trenching) or debris will be returned to its original location. Contained media (e.g., soil managed as waste) as well as other IDW will be segregated to the greatest extent possible to minimize generation of hazardous, radioactive, or mixed waste. Hazardous material used at the sites will be controlled in order to limit unnecessary generation of hazardous or mixed waste. Administrative controls, including decontamination procedures and waste characterization strategies, will minimize waste generated during investigations. 


\subsection{Potential Waste Streams}

Waste generated during the corrective action activities may include the following potential waste streams:

- Personal protective equipment and disposable sampling equipment (e.g., plastic, paper, sample containers, aluminum foil, spoons, bowls)

- Underground storage tanks and associated piping

- Underground storage tanks contents

- Decontamination rinsate

- Environmental media (e.g., soil)

- Remediation debris in investigation area

- Field-screening waste (e.g., spent solvent, disposable sampling equipment, and/or PPE contaminated by field-screening activities)

The onsite management and ultimate disposition of wastes will be determined based on a determination of the waste type (e.g., sanitary, low-level, hazardous, hydrocarbon, mixed), or the combination of waste types. A determination of the waste type will be guided by several factors, including, but not limited to: the analytical results of samples either directly or indirectly associated with the waste, historical site knowledge, process knowledge of waste generation, field observations, field-monitoring/screening results, and/or radiological survey/swipe results.

Table 4-2 of the NV/YMP Radiological Control Manual (NNSA/NSO, 2004) shall be used to determine whether such materials may be declared nonradioactive. Onsite IDW management requirements by waste type are detailed in the following sections. Applicable waste management regulations and requirements are listed in Table 6-1.

\subsubsection{Sanitary Waste}

Sanitary waste generated at each CAS will meet the definition of a solid waste and be collected, managed, and disposed of in accordance with the Permit to Operate a Class III Industrial Solid Waste Disposal Site at the NTS U10c Disposal Site. 
Table 6-1

Waste Management Regulations and Requirements

\begin{tabular}{|c|c|c|}
\hline Waste Type & Federal Regulation & Additional Requirements \\
\hline Solid (nonhazardous) & $\mathrm{N} / \mathrm{A}$ & $\begin{array}{c}\text { NRS }^{\mathrm{a}} 444.440-444.620 \\
\text { NAC }^{\mathrm{b}} 444.570-444.7499 \\
\text { NTS Landfill Permit SW13.097.04 } \\
\text { NTS Landfill Permit SW13.097.03 }\end{array}$ \\
\hline Liquid/Rinsate (nonhazardous) & $\mathrm{N} / \mathrm{A}$ & $\begin{array}{l}\text { Water Pollution Control General Permit } \\
\text { GNEV93001, Rev. 3iii }\end{array}$ \\
\hline Hazardous & $\begin{array}{c}\text { RCRA }^{f} \\
40 \text { CFR } 260-282\end{array}$ & $\begin{array}{c}\text { NRS }^{\mathrm{a}} 459.400-459.600 \\
\mathrm{NAC}^{\mathrm{b}} 444.850-444.8746 \\
\mathrm{POC}^{\mathrm{g}}\end{array}$ \\
\hline Low-Level Radioactive & N/A & DOE Orders and NTSWAC ${ }^{\text {h }}$ \\
\hline Mixed & $\begin{array}{c}\text { RCRA }^{f} \\
40 \text { CFR 260-282 }\end{array}$ & $\begin{array}{l}\text { NTSWAC } \\
\text { POC }^{\mathrm{g}}\end{array}$ \\
\hline Hydrocarbon & $\mathrm{N} / \mathrm{A}$ & $\begin{array}{c}\text { NTS Landfill Permit SW13.097.02i } \\
\text { NAC }^{\text {b }} 445 A .2272\end{array}$ \\
\hline Polychlorinated Biphenyls & $\begin{array}{l}\text { TSCA }^{\mathrm{j}} \\
40 \text { CFR } 761\end{array}$ & $\begin{array}{l}\text { NRS }^{a} 459.400-459.600 \\
\text { NAC }^{b} 444.940-444.9555\end{array}$ \\
\hline Asbestos & $\begin{array}{l}\text { TSCA }^{\mathrm{j}} \\
40 \text { CFR } 763\end{array}$ & $\begin{array}{l}\text { NRS }^{a} 618.750-618.840 \\
\text { NAC }^{b} 444.965-444.976\end{array}$ \\
\hline
\end{tabular}

${ }^{a}$ Nevada Revised Statutes (NRS, 2003a, b, c).

${ }^{\mathrm{b}}$ Nevada Administrative Code (NAC, 2006a, e).

${ }^{\mathrm{c}}$ Area 23 Class II Solid Waste Disposal Site (NDEP, 1997a).

${ }^{d}$ Area 9 Class III Solid Waste Disposal Site (NDEP, 1997c).

e Nevada Test Site Sewage Lagoons (NDEP, 1999).

${ }^{\mathrm{f}}$ Resource Conservation and Recovery Act (CFR, 2006a).

${ }^{9}$ Nevada Test Site Performance Objective for the Certification of Nonradioactive Hazardous Waste (BN, 1995).

${ }^{\mathrm{h}}$ Nevada Test Site Waste Acceptance Criteria (NNSA/NSO, 2006b).

'Area 6 Class III Solid Waste Disposal Site for Hydrocarbon Waste (NDEP, 1997b).

${ }^{\mathrm{j}}$ Toxic Substances Control Act (CFR, 2006b, c).

$\mathrm{CFR}=$ Code of Federal Regulations

DOE $=$ U.S. Department of Energy

$\mathrm{N} / \mathrm{A}=$ Not applicable

NAC $=$ Nevada Administrative Code

NDEP = Nevada Division of Environmental Protection

NRS $=$ Nevada Revised Statutes

NTS $=$ Nevada Test Site

NTSWAC = Nevada Test Site Waste Acceptance Criteria

$\mathrm{POC}=$ Performance Objective for the Certification of Nonradioactive Hazardous Waste

RCRA = Resource Conservation and Recovery Act

TSCA = Toxic Substances Control Act 
Office trash and lunch waste will be placed in the dumpster to be transported to the sanitary landfill for disposal. Sanitary IDW generated at each CAS will be collected only in plastic bags, sealed, labeled with the CAS number from each site in which it was generated, and dated. The waste will then be placed in a roll-off box located in Mercury or other approved roll-off box location. The number of bags of sanitary IDW placed in the roll-off box will be counted as they are placed in the roll-off box, noted in a log, and documented in the Field Activity Daily Log. These logs will provide necessary tracking information for ultimate disposal in the U10c Industrial Waste Landfill.

\subsubsection{Low-Level Radioactive Waste}

Radiological swipe surveys and/or direct-scan surveys may be conducted on reusable sampling equipment and the PPE and disposable sampling equipment waste streams exiting a controlled area. This allows for the immediate segregation of radioactive waste from waste that may be unrestricted regarding radiological release. Removable contamination limits, as defined in Table 4-2 of the NV/YMP Radiological Control Manual (NNSA/NSO, 2004), will be used to determine whether such waste may be declared unrestricted regarding radiological release versus declared as radioactive waste. Direct sampling of the waste may be conducted to aid in determining whether a particular waste unit (e.g., drum of soil) contains low-level radioactive waste, as necessary. Waste that is determined to be below Table 4-2 values of either direct radiological survey/swipe results or through process knowledge, will not be managed as potential radioactive waste but in accordance with the appropriate section of this SAFER Plan. Wastes in excess Table 4-2 values will be managed as potential radioactive waste and in accordance with this section and applicable sections of this SAFER Plan.

Low-level radioactive waste, if generated, will be managed in accordance with the contractor-specific waste certification program plan, DOE Orders, and the requirements of the current version of the Nevada Test Site Waste Acceptance Criteria (NTSWAC) (NNSA/NSO, 2006b). The waste will be marked with the words "Radioactive Material Pending Analysis.” The waste drum will be transported in accordance with Department of Transportation (DOT) regulations, and disposed under NTSWAC requirements pending certification (NNSA/NSO, 2006b). 


\subsubsection{Hazardous Waste}

Waste accumulation areas for CAU 124 will be established according to the needs of the project. Satellite accumulation areas and hazardous waste accumulation areas (HWAAs) will be managed consistently with the requirements of federal and state regulations (CFR, 2006a; NAC, 2006b). The HWAAs will be controlled properly for access, and will be equipped with spill kits and appropriate spill containment. Suspected hazardous wastes will be placed in DOT-compliant containers.

Containerized hazardous waste will be handled, inspected, and managed in accordance with Title 40 CFR 265 Subpart I (CFR, 2006a). These provisions include managing waste in containers compatible with waste type, and segregating incompatible waste types so that in the event of a spill, leak, or release, such wastes shall not be in contact. The HWAAs will be covered under a site-specific emergency response and contingency action plan until such time that the waste is determined to be nonhazardous or all containers of hazardous waste have been removed from the storage area. Hazardous waste will be characterized in accordance with the requirement of Title 40 CFR 261. Resource Conservation and Recovery Act-“listed" waste has not been identified at CAU 124. Waste determined to be hazardous will be managed and transported, in accordance with RCRA and DOT requirements, to a permitted treatment, storage, and disposal facility (CFR, 2006a).

\subsubsection{Hydrocarbon Waste}

Hydrocarbon soil waste containing more than 100 milligrams per kilogram of TPH will be managed on site in a drum or other appropriate container until fully characterized. Hydrocarbon waste may be disposed of at a designated hydrocarbon landfill (NDEP, 1997b), an appropriate hydrocarbon waste management facility (e.g., recycling facility), or other method in accordance with State of Nevada regulations.

\subsubsection{Mixed Low-Level Waste}

Mixed waste, if generated, shall be managed as per Sections 6.2.3 and 6.2.2 of this SAFER Plan or subject to agreements between NNSA/NSO and NDEP, as well as DOE requirements for radioactive waste. The waste will be marked with the words "Hazardous Waste Pending Analysis and Radioactive Material Pending Analysis.” Mixed waste will not be stored for a period that exceeds the requirements of RCRA unless subject to agreements between NNSA/NSO and the State of Nevada. 
Mixed waste shall be transported via an approved hazardous waste/radioactive waste transporter to the NTS transuranic waste storage pad for storage pending treatment or disposal. Mixed waste with hazardous waste constituent concentrations below Land Disposal Restrictions may be disposed at the NTS Area 5 Radioactive Waste Management Site, if the waste meets the requirements of the NTSWAC (NNSA/NSO, 2006b), the NTS NDEP permit for a Hazardous Waste Management Facility as issued 2005 (NEV HW0021 [NDEP, 2005]), and the RCRA Part B Permit Application for Waste Management Activities at the Nevada Test Site (DOE/NV, 1999). Mixed waste constituent concentrations exceeding Land Disposal Restrictions will require development of a treatment and disposal plan under the requirements of the Mutual Consent Agreement between DOE and the State of Nevada (NDEP, 1995).

\subsubsection{Polychlorinated Biphenyls}

The management of polychlorinated biphenyls (PCBs) is governed by the Toxic Substances Control Act (USC, 1976) and its implementing regulations at 40 CFR 761 (CFR, 2006b). Contamination of PCBs may be found as a sole contaminant or in combination with other types of waste discussed in this document. For example, PCBs may be a co-contaminant in soil that contains a RCRA “characteristic” waste (PCB/hazardous waste), or in soil that contains radioactive wastes (PCB/radioactive waste), or in mixed waste (PCB/radioactive/hazardous waste). The IDW will be initially evaluated using analytical results for media samples from the investigation. If any type of PCB waste is generated, it will be managed according to 40 CFR 761 (CFR, 2006b) as well as State of Nevada requirements, (NAC, 2006a) guidance, and agreements with NNSA/NSO.

\subsection{Management of Specific Waste Streams}

\subsubsection{Personal Protective Equipment}

Personal protective equipment and disposable sampling equipment will be visually inspected for stains, discoloration, and gross contamination as waste is generated; and evaluated for radiological contamination. Staining and/discoloration will be assumed to be the result of contact with potentially contaminated media such as soil, sludge, or liquid. Gross contamination is the visible contamination of an item (e.g., clumps of soil/sludge on a sampling spoon or free liquid smeared on a glove). While gross contamination can often be removed through decontamination methods, removal of gross 
contamination from small items, such as gloves or booties typically is not conducted.

Investigation-derived waste that meets this description will be segregated and managed as potentially "characteristic" hazardous waste. This segregated population of waste will either: (1) be assigned the characterization of the soil/sludge that was sampled, (2) be sampled directly, or (3) undergo further evaluation using the soil/sludge sample results to determine how much soil/sludge would need to be present in the waste to exceed regulatory levels. Waste determined to be hazardous will be entered into an approved waste management system, and managed and dispositioned according to RCRA requirements; or subject to agreements between NNSA/NSO and the State of Nevada. The PPE and equipment not visibly stained, discolored, or grossly contaminated, and within the radiological free-release criteria, will be managed as nonhazardous sanitary waste.

\subsubsection{Management of Decontamination Rinsate}

Rinsate at CAU 124 will not be considered hazardous waste unless there is evidence that the rinsate may display a RCRA characteristic. Evidence may include the presence of a visible sheen, $\mathrm{pH}$, or association with equipment/materials used to respond to a release/spill of a hazardous waste/substance. Decontamination rinsate that is potentially hazardous (using associated sample results and/or process knowledge) will be managed as characteristic hazardous waste (CFR, 2006a). The regulatory status of the potentially hazardous rinsate will be determined through the application of associated sample results or through direct sampling. If associated samples do not indicate the presence of hazardous constituents, then rinsate will be considered to be nonhazardous.

The disposal of nonhazardous rinsate will be consistent with guidance established in current NNSA/NSO Fluid Management Plans for the NTS as follows:

- Rinsate that is determined to be nonhazardous and contaminated to less than 5x Safe Drinking Water Standards (SDWS) is not restricted as to disposal. Nonhazardous rinsate which is contaminated at 5x to 10x SDWS will be disposed of in an established infiltration basin or solidified and disposed of as sanitary waste or low-level waste in accordance with the respective sections of this SAFER Plan.

- Nonhazardous rinsate, contaminated at greater than 10x SDWS, will be disposed of in a lined basin or solidified and disposed of as sanitary waste or low-level waste in accordance with the respective sections of this SAFER Plan. 


\subsubsection{Management of Soil}

This waste stream consists of soil removed for disposal during soil sampling, excavation, and/or drilling. This waste stream will be characterized based on laboratory analytical results from representative locations. If the soil is determined to potentially contain COCs, the material will be managed either on site or containerized for transportation to an appropriate disposal site.

Onsite management of the waste soil will be allowed only if it is managed within an area of concern and appropriate to defer the management of the waste until the final remediation of the site. If this option is chosen, the waste soil shall be protected from run-on and run-off using appropriate protective measures based on the type of contaminant(s) (e.g., covered with plastic and bermed).

Management for soil waste disposal consists of placing the waste in containers, labeling the containers, temporarily storing the containers until shipped, and then shipping the waste to a disposal site. The containers, labels, management of stored waste, transport to the disposal site, and disposal shall be appropriate for the type of waste (e.g., hazardous, hydrocarbon, mixed).

Note that soils placed back into a borehole, or excavation in the same approximate location from which it originated, is not considered to be a waste.

\subsubsection{Management of Debris}

This waste stream can vary depending on site conditions. Debris that requires removal for the investigation activities (soil sampling, excavation, and/or drilling) must be characterized for proper management and disposition. Historical site knowledge, process knowledge of waste generation, field observations, field-monitoring/screening results, radiological survey/swipe results and/or the analytical results of samples; either directly or indirectly associated with the waste, may be used to characterized the debris. Debris will be inspected visually for stains, discoloration, and gross contamination. Debris may be deemed reusable, recyclable, sanitary waste, hazardous waste, PCB waste, or low-level waste. Waste that is not sanitary will be entered into an approved waste management system, where it will be managed and dispositioned according to federal, state requirements, and agreements between NNSA/NSO and the State of Nevada. The debris will be either managed on site, by berming and covering next to the excavation, placement in a container(s), 
or left on the footprint of the CAS and its disposition deferred until implementation of corrective action at the site.

\subsubsection{Field-Screening Waste}

The use of field test kits and/or instruments may result in the generation of small quantities of hazardous wastes. If hazardous waste is produced by field screening, it will be segregated from other IDW and managed in accordance with the hazardous waste regulations (CFR, 2006a). For sites where field-screening samples contain radioactivity above background levels, field-screening methods with the potential to generate hazardous waste will not be used; thus avoiding the potential to generate mixed waste. In the event a mixed waste is generated, the waste will be managed in accordance with Section 6.2.5 of this document. 


\subsection{Quality Assurance/Quality Control}

The objective of the characterization activities described in this SAFER Plan is to collect accurate and defensible data to support the selection and implementation of a closure alternative for each CAU 124 CAS. Sections 7.1 and 7.2 discuss the collection of required quality control (QC) samples in the field and quality assurance (QA) requirements for laboratory/analytical data to achieve closure. Unless otherwise stated in this SAFER Plan, or required by the results of the DQO process (see Appendix B), this investigation will adhere to the Industrial Sites QAPP (NNSA/NV, 2002a).

\subsection{Sample Collection Activities}

Field QC samples will be collected in accordance with established procedures. Field QC samples are collected and analyzed to aid in determining the validity of environmental sample results. The number of required QC samples depends on the types and number of environmental samples collected. The minimum frequency of collecting and analyzing QC samples for this investigation, as determined in the DQO process, include:

- Trip blanks (1 per sample cooler containing volatile organic compound (VOC) environmental samples)

- Equipment rinsate blanks (1 per sampling event for each type of decontamination procedure)

- $\quad$ Source blanks (1 per uncharacterized lot of source material that contacts sampled media)

- Field duplicates (1 per 20 environmental samples or 1 per CAS per matrix, if less than 20 collected)

- $\quad$ Field blanks (1 per CAS)

- Laboratory QC samples (1 per 20 environmental samples or 1 per CAS per matrix, if less than 20 collected)

Additional QC samples may be submitted based on site conditions at the discretion of the Task

Manager or SS. Field QC samples shall be analyzed using the same analytical procedures implemented for associated environmental samples. Additional details regarding field QC samples are available in the Industrial Sites QAPP (NNSA/NV, 2002a). 


\subsection{Applicable Laboratory/Analytical Data Quality Indicators}

The DQIs are qualitative and quantitative descriptors used in interpreting the degree of acceptability or utility of data. Data quality indicators are used to evaluate the entire measurement system and laboratory measurement processes (i.e., analytical method performance) as well as individual analytical results (i.e., parameter performance). Data quality and usability to make DQO decisions will be assessed based on the following DQIs:

- Precision

- Accuracy/bias

- Representativeness

- Comparability

- Completeness

- Sensitivity

Table 7-1 provides the established analytical method/measurement system performance criteria for each of the DQIs and the potential impacts to the decision if the criteria are not met. The following subsections discuss the DQIs to be used to assess the quality of laboratory data. Due to changes in analytical methodology and changes in analytical laboratory contracts, criteria for precision and accuracy in Tables 3-4 and 3-5 that vary from corresponding information in the QAPP will supersede that information in the Industrial Sites QAPP (NNSA/NV, 2002a).

Table 7-1

Laboratory and Analytical Performance Criteria for CAU 124 Data Quality Indicators (Page 1 of 2)

\begin{tabular}{||c|l|l||}
\hline $\begin{array}{c}\text { Data Quality } \\
\text { Indicator }\end{array}$ & \multicolumn{1}{|c|}{ Performance Metric } & \multicolumn{1}{|c|}{$\begin{array}{c}\text { Potential Impact on Decision } \\
\text { If Performance Metric Not Met }\end{array}$} \\
\hline Precision & $\begin{array}{l}\text { At least 80\% of the sample results for each } \\
\text { measured contaminant are not qualified for } \\
\text { precision based on the criteria for each analytical } \\
\text { method-specific and laboratory-specific criteria } \\
\text { presented in Section 7.2.1. }\end{array}$ & $\begin{array}{l}\text { If the performance metric is not met, the } \\
\text { affected analytical results from each } \\
\text { affected CAS will be assessed to determine } \\
\text { whether there is sufficient confidence in } \\
\text { analytical results to use the data in making } \\
\text { DQO decisions. }\end{array}$ \\
\hline Accuracy & $\begin{array}{l}\text { At least 80\% of the sample results for each } \\
\text { measured contaminant are not qualified for } \\
\text { accuracy based on the method-specific and } \\
\text { laboratory-specific criteria presented in } \\
\text { Section 7.2.2. }\end{array}$ & $\begin{array}{l}\text { If the performance metric is not met, the } \\
\text { affected analytical results from each } \\
\text { affected CAS will be assessed to determine } \\
\text { whether there is sufficient confidence in } \\
\text { analytical results to use the data in making } \\
\text { DQO decisions. }\end{array}$ \\
\hline Sensitivity & $\begin{array}{l}\text { Minimum detectable concentrations are less than } \\
\text { or equal to respective FALs. }\end{array}$ & $\begin{array}{l}\text { Cannot determine whether COCs are } \\
\text { present or migrating at levels of concern. }\end{array}$ \\
\hline
\end{tabular}


Table 7-1

Laboratory and Analytical Performance Criteria for CAU 124 Data Quality Indicators (Page 2 of 2)

\begin{tabular}{||c|l|l||}
\hline $\begin{array}{c}\text { Data Quality } \\
\text { Indicator }\end{array}$ & \multicolumn{1}{|c|}{ Performance Metric } & \multicolumn{1}{|c|}{$\begin{array}{c}\text { Potential Impact on Decision } \\
\text { If Performance Metric Not Met }\end{array}$} \\
\hline \hline Comparability & $\begin{array}{l}\text { Sampling, handling, preparation, analysis, } \\
\text { reporting, and data validation are performed } \\
\text { using standard methods and procedures. }\end{array}$ & $\begin{array}{l}\text { Inability to combine data with data obtained } \\
\text { from other sources and/or inability to } \\
\text { compare data to regulatory action levels. }\end{array}$ \\
\hline Representativeness & $\begin{array}{l}\text { Samples contain contaminants at concentrations } \\
\text { present in the environmental media from which } \\
\text { they were collected. }\end{array}$ & $\begin{array}{l}\text { Analytical results will not represent true site } \\
\text { conditions. Inability to make appropriate } \\
\text { DQO decisions. }\end{array}$ \\
\hline Completeness & $\begin{array}{l}80 \% \text { of the CAS-specific COPCs have valid } \\
\text { results. } \\
100 \% \text { of CAS-specific targeted contaminants } \\
\text { have valid results. }\end{array}$ & $\begin{array}{l}\text { Cannot support/defend decision on whether } \\
\text { COCs are present. }\end{array}$ \\
\hline $\begin{array}{l}\text { Extent Completeness } \\
\text { Clean Closure } \\
\text { Completeness }\end{array}$ & $\begin{array}{l}100 \% \text { of COCs used to define extent have valid } \\
\text { results. }\end{array}$ & $\begin{array}{l}\text { Extent of contamination cannot be } \\
\text { accurately determined. }\end{array}$ \\
\hline
\end{tabular}

$\mathrm{COC}=$ Contaminant of concern

$\mathrm{COPC}=$ Contaminant of potential concern

$\mathrm{DQO}=$ Data quality objective

$\mathrm{FAL}=$ Final action level

\subsubsection{Precision}

Precision is a measure of the repeatability of the analysis process from sample collection through analysis results used to assess the variability between two equal samples.

Determinations of precision will be made for laboratory duplicate samples. The laboratory sample duplicates are an aliquot, or subset, of a field sample generated in the laboratory. They are not a separate sample but a split, or portion, of an existing sample. Samples may include matrix spike duplicate and laboratory control sample (LCS) duplicate samples for organic, inorganic, and radiological analyses.

Precision is a quantitative measure used to assess overall analytical method and field sampling performance as well as to assess the need to "flag” (qualify) individual parameter results when corresponding QC sample results are not within established control limits. 
The criteria for the assessment of chemical precision used when both results are greater than or equal to $5 x$ reporting limit (RL) is 20 and 35 percent for aqueous and soil samples, respectively. When either result is less than $5 x$ RL, a control limit of $\pm 1 x$ RL and $\pm 2 x$ RL for aqueous and soil samples, respectively, is applied to the absolute difference.

The criteria used for the assessment of radiological precision when both results are greater than or equal to 5x MDC is 20 and 35 percent for aqueous and soil samples, respectively. When either result is less than 5x MDC, the normalized difference should be between -2 and +2 for aqueous and soil samples. The parameters to be used for assessment of precision for duplicates are listed in Table 3-5.

Values outside the specified criteria do not necessarily result in the qualification of analytical data. It is only one factor in making an overall judgment about the quality of the reported analytical results. The performance metric for assessing the DQI of precision on DQO decisions (see Table 7-1) is that at least 80 percent of sample results for each measured contaminant are not qualified due to duplicates exceeding the criteria. If this performance is not met, an assessment will be conducted on the impacts to DQO decisions specific to affected contaminants and CASs in the CR.

\subsubsection{Accuracy}

Accuracy is a measure of the closeness of an individual measurement to the true value used to assess the performance of laboratory measurement processes.

Accuracy is determined by analyzing a reference material of known parameter concentration or by re-analyzing a sample to which a material of known concentration or amount of parameter has been added (spiked). Accuracy will be evaluated based on results from three types of spiked samples: matrix spike (MS), LCS, and surrogates (organics). The LCS sample is analyzed with the field samples using the same sample preparation, reagents, and analytical methods employed for the samples. One LCS will be prepared with each batch of samples for analysis by a specific measurement.

The criteria used for the assessment of inorganic chemical accuracy are 75 to 125 percent for MS recoveries and 80 to 120 percent for LCS recoveries. For organic chemical accuracy, MS and LCS laboratory-specific percent recovery criteria developed and generated in-house by the laboratory 
according to approved laboratory procedures are applied. The criteria used for the assessment of radiochemical accuracy are 80 to 120 percent for LCS and MS recoveries.

Values outside the specified criteria do not necessarily result in the qualification of analytical data. It is only one factor in making an overall judgment about the quality of the reported analytical results. Factors beyond laboratory control, such as sample matrix effects, can cause the measured values to be outside of the established criteria. Therefore, the entire sampling and analytical process may be evaluated when determining the usability of the affected data.

The performance metric for assessing the DQI of accuracy on DQO decisions (see Table 7-1) is that at least 80 percent of the sample results for each measured contaminant are not qualified for accuracy. If this performance is not met, an assessment will be conducted in the CR on the impacts to DQO decisions specific to affected contaminants and CASs.

\subsubsection{Representativeness}

Representativeness is the degree to which sample characteristics accurately and precisely represent characteristics of a population or an environmental condition (EPA, 2002). Representativeness is assured by carefully developing the sampling strategy during the DQO process such that false negative and false positive decision errors are minimized. The criteria listed in DQO Step 6 - Specify the Tolerable Limits on Decision Errors are:

- For Decision I judgmental sampling, having a high degree of confidence that the sample locations selected will identify COCs, if present, within the CAS.

- Having a high degree of confidence that analyses conducted will be sufficient to detect COCs present in the samples.

- For Decision II, having a high degree of confidence that the sample locations selected will identify the extent of COCs.

These are qualitative measures that will be used to assess measurement system performance for representativeness. The assessment of this qualitative criterion will be presented in the CR. 


\subsubsection{Comparability}

Comparability is a qualitative parameter expressing the confidence with which one dataset can be compared to another (EPA, 2002). The criteria for the evaluation of comparability will be that sampling, handling, preparation, analysis, reporting, and data validation were performed using approved standard methods and procedures. This will ensure that data from this project can be compared to regulatory action levels that were developed based on data generated using the same or comparable methods and procedures. An evaluation of comparability will be presented in the CR.

\subsubsection{Completeness}

Completeness is defined as generating sufficient data of the appropriate quality to satisfy the data needs identified in the DQOs. For judgmental sampling, completeness will be evaluated using both a quantitative measure and a qualitative assessment. The quantitative measurement used to evaluate completeness is presented in Table 7-1 and is based on the percentage of measurements judged to be valid. For the judgmental sampling approach, the completeness goal for targeted contaminants and the remaining COPCs is 100 and 80 percent, respectively. If this goal is not achieved, the dataset will be assessed for potential impacts on DQO decision-making.

The qualitative assessment of completeness is an evaluation of the information sufficiency of information available to make DQO decisions. This assessment will be based on meeting the data needs identified in the DQOs and presented in the CR. If it is determined that the number of samples do not meet completeness criteria, additional samples will be collected.

\subsubsection{Sensitivity}

Sensitivity is the capability of a method or instrument to discriminate between measurement responses representing different levels of the variable of interest (EPA, 2002). The evaluation criteria for this parameter is that measurement sensitivity (detection limits) will be less than or equal to the corresponding FALs. If this criterion is not achieved, the affected data will be assessed for usability and potential impacts on meeting site characterization objectives. This assessment will be presented in the CR. 


\subsection{References}

Adams, S., IT Corporation. 2002. Memorandum to B. Iverson (GeoTrans) entitled, "Radiological Contaminants of Potential Concern (COPC) at the Bunkers of Corrective Action Unit (CAU) 204,” 29 March. Las Vegas, NV.

ASTM, see American Society for Testing and Materials.

American Society for Testing and Materials. 1995. Standard Guide for Risk-Based Corrective Action Applied at Petroleum Release Sites, ASTM E 1739-95 (Reapproved 2002). Philadelphia, PA.

BN, see Bechtel Nevada.

Bechtel Nevada. 1995. Nevada Test Site Performance Objective for Certification of Nonradioactive Hazardous Waste, Rev. 0, G-E11/96.01. Las Vegas, NV.

CFR, see Code of Federal Regulations.

Code of Federal Regulations. 2006a. Title 40 CFR Parts 260 - 282, “Hazardous Waste Management.” Washington, DC: U.S. Government Printing Office.

Code of Federal Regulations. 2006b. Title 40 CFR 761, "Polychlorinated Biphenyls (PCBs) Manufacturing, Processing, Distribution in Commerce and Prohibitions.” Washington, DC: U.S. Government Printing Office.

Code of Federal Regulations. 2006c. Title 40 CFR, Part 763, “Asbestos.” Washington, DC: U.S. Government Printing Office.

DOE, see U.S. Department of Energy.

DOE/NV, see U.S. Department of Energy, Nevada Operations Office.

EG\&G/EM, see EG\&G Energy Measurements.

EPA, see U.S. Environmental Protection Agency.

EG\&G Energy Measurements. 1975. Oblique Aerial Photograph N-NF-451 of EPA Farm, September. Nellis Air Force Base, NV: Remote Sensing Laboratory Photo Library.

FFACO, see Federal Facility Agreement and Consent Order.

Federal Facility Agreement and Consent Order. 1996 (as amended). Agreed to by the State of Nevada, the U.S. Department of Energy, and the U.S. Department of Defense. 
Madsen, D., Bechtel Nevada. 2006. Electronic correspondence with C. Sloop (SNJV) regarding CAS 08-02-01 information, 26 May. Las Vegas, NV.

Metcalf, J., Sandia National Laboratories. 2004. Record of Telecon with T. Diaz (SNJV) regarding Area 16 Camp, 20 January. Las Vegas, NV.

Moore, J., Science Applications International Corporation. 1999. Memorandum to M. Todd (SAIC) entitled, "Background Concentrations for NTS and TTR Soil Samples,” 3 February. Las Vegas, NV: IT Corporation.

Murphy, T., Bureau of Federal Facilities. 2004. Letter to R. Bangerter (NNSA/NSO) entitled, "Review of Industrial Sites Project Document Guidance for Calculating Industrial Sites Project Remediation Goals for Radionuclides in Soil Using the Residual Radiation (RESRAD) Computer Code." 19 November. Las Vegas, NV.

NAC, see Nevada Administrative Code.

NBMG, see Nevada Bureau of Mines and Geology.

NCRP, see National Council on Radiation Protection and Measurements.

NDEP, see Nevada Division of Environmental Protection.

NNSA/NSO, see U.S. Department of Energy, National Nuclear Security Administration Nevada Site Office.

NNSA/NV, see U.S. Department of Energy, National Nuclear Security Administration Nevada Operations Office.

NRS, see Nevada Revised Statutes.

National Council on Radiation Protection and Measurements. 1999. Recommended Screening Limits for Contaminated Surface Soil and Review of Factors Relevant to Site-Specific Studies, NCRP Report No. 129. Bethesda, MD.

Nevada Administrative Code. 2005. NAC 459.9972, “UST Closure” Carson City, NV. As accessed at http://www.leg.state.nv.us/nac on 15 December 2006.

Nevada Administrative Code. 2006a. NAC 444, “Sanitation.” Carson City, NV. As accessed at http://www.leg.state.nv.us/nac on 15 December.

Nevada Administrative Code. 2006b. NAC 445A, "Water Controls.” Carson City, NV. As accessed at http://www.leg.state.nv.us/nac on 15 December. 
Nevada Administrative Code. 2006c. NAC 445A.227, "Contamination of Soil: Order by Director for Corrective Action; Factors To Be Considered in Determining Whether Corrective Action Required.” Carson City, NV. As accessed at http://www.leg.state.nv.us/nac on 15 December.

Nevada Administrative Code. 2006d. NAC 445A.22705, “Contamination of Soil: Evaluation of Site by Owner or Operator; Review of Evaluation by Division.” Carson City, NV. As accessed at http://www.leg.state.nv.us/nac on 15 December.

Nevada Administrative Code. 2006e. NAC 445A.2272, "Contamination of Soil: Establishment of Action Levels.” Carson City, NV. As accessed at http://www.leg.state.nv.us/nac on 15 December.

Nevada Bureau of Mines and Geology. 1998. Mineral and Energy Resource Assessment of the Nellis Air Force Range, Open-File Report 98-1. Reno, NV.

Nevada Division of Environmental Protection. 1995. Mutual Consent Agreement between the State of Nevada and the U.S. Department of Energy for the Storage of Low-Level Land Disposal Restricted Mixed Waste. Carson City, NV.

Nevada Division of Environmental Protection. 1997a. Class II Solid Waste Disposal Site for Municipal and Solid Waste, Area 23 of the NTS, Permit SW 13-097-04. Carson City, NV.

Nevada Division of Environmental Protection. 1997b (as amended in August 2000). Class III Solid Waste Disposal Site for Hydrocarbon Burdened Soils, Area 6 of the NTS, Permit SW 1309702. Carson City, NV.

Nevada Division of Environmental Protection. 1997c (as amended in August 2000). Class III Solid Waste Disposal Site; UIOC, Area 9 of the NTS, Permit SW 13-097-03. Carson City, NV.

Nevada Division of Environmental Protection. 1999. State of Nevada Water Pollution Control General Permit, No. GNEV93001. Carson City, NV.

Nevada Division of Environmental Protection. 2005. Hazardous Waste Management Facility Draft Permit, No. NEV HW0021. Carson City, NV.

Nevada Revised Statutes. 2003a. NRS 444.440 - 444.620, “Collection and Disposal of Solid Waste.” Carson City, NV.

Nevada Revised Statutes. 2003b. NRS 459.400 - 459.600, “Disposal of Hazardous Waste.” Carson City, NV.

Nevada Revised Statutes. 2003c. NRS 618.750-618.840 “Disposal of Hazardous Waste.” Carson City, NV. 
Nicosia, W., IT Corporation. 2003. Memorandum to M. England (SAIC) entitled, "Radiological Land Area Surveys of Various Locations at the Nevada Test Site for Preliminary Assessments," 3 March.

PNNL, see Pacific Northwest National Laboratory.

Paar, J.G., and D.R. Porterfield. 1997. Evaluation of Radiochemical Data Usability, April, ES/ER/MS-5. Oak Ridge, TN: U.S. Department of Energy.

Pacific Northwest National Laboratory. 2005. Visual Sampling Plan Version 4.0, User’s Guide PNNL-14002. Richland, WA.

REECo, see Reynolds Electrical \& Engineering Co., Inc.

Reynolds Electrical \& Engineering Co., Inc. 1962. Engineering drawing Y-16-M3 entitled, “Area 16 Trailer Housing Fuel Oil \& Propane Piping Plan,” 21 March. Mercury, NV: Archives and Records Center.

Reynolds Electrical \& Engineering Co., Inc. 1966. Engineering drawing, 15-A1S-M1, entitled "Nevada Test Site-Area 15 USPHS Experimental Farm Auxiliary Irrigation System Mechanical Plan \& Section,” 22 June. Las Vegas, NV.

Reynolds Electrical \& Engineering Co., Inc. 1991. Nevada Test Site Inventory of Inactive and Abandoned Facilities and Waste Sites, Areas 11-15, Volume 3 of 5, DOE/NV/10630-18. Las Vegas, NV.

SAIC, see Science Applications International Corporation.

Science Applications International Corporation. 2003. Surface Geophysical Survey Final Report Corrective Action Units Nevada Test Site, May. Prepared for Shaw Environmental, Inc. Las Vegas, NV.

SNJV GIS System, see Stoller-Navarro Joint Venture Geographic Information Systems.

Stoller-Navarro Joint Venture Geographic Information Systems. 2007. ESRI Arc GIS Software.

SWRHL, see Southwestern Radiological Health Laboratory.

Southwestern Radiological Health Laboratory. 1967. Status of the Nevada Test Site Experimental Farm Summary Report for July 1964-December 1965, SWRHL-36r. Prepared by R.L. Douglas for the U.S. Atomic Energy Commission. Las Vegas, NV: U.S. Public Health Service.

USC, see United States Code. 
United States Code. 1976. 15 USC 2601 et seq., “Toxic Substances Control Act.” Enacted by Public Law No. 94-469, as amended. Washington, DC: U.S. Government Printing Office.

U.S. Department of Energy. 1993. Radiation Protection of the Public and the Environment, DOE Order 5400.5, Change 2. Washington, DC: U.S. Government Printing Office.

U.S. Department of Energy. 1997. The Procedures Manual of the Environmental Measurements Laboratory, HASL-300, 28th Ed., Vol. I. New York, NY.

U.S. Department of Energy, National Nuclear Security Administration Nevada Operations Office. 2002a. Industrial Sites Quality Assurance Project Plan, Nevada Test Site, Nevada, Rev. 3, DOE/NV--372. Las Vegas, NV.

U.S. Department of Energy, National Nuclear Security Administration Nevada Operations Office. 2002b. Underground Test Area Project Waste Management Plan, DOE/NV--343-Rev. 2. Las Vegas, NV.

U.S. Department of Energy, Nevada Operations Office. 1999. Water Pollution Control General Permit, GNEV. Las Vegas, NV.

U.S. Department of Energy, Nevada Operations Office. 2000. United States Nuclear Tests, July 1945 through September 1992, DOE/NV-209-Rev 15. Las Vegas, NV.

U.S. Department of Energy, National Nuclear Security Administration Nevada Site Office. 2004. NV/YMP Radiological Control Manual, Rev. 5, DOE/NV/11718-079, UC-702. Prepared by A.L. Gile of Bechtel Nevada. Las Vegas, NV.

U.S. Department of Energy, National Nuclear Security Administration Nevada Site Office. 2006a. Industrial Sites Project Establishment of Final Action Levels, Rev. 0, DOE/NV--1107. Las Vegas, NV.

U.S. Department of Energy, National Nuclear Security Administration Nevada Site Office. 2006b. Nevada Test Site Waste Acceptance Criteria, Rev. 6-01, DOE/NV--325. Las Vegas, NV.

U.S. Environmental Protection Agency. 1973. Status of the Environmental Protection Agency's Nevada Test Site Experimental Dairy Herd January 1, 1969 - December 31, 1970, NERC-LV-539-22. Prepared by D.D. Smith for the U.S. Atomic Energy Commission. Las Vegas, NV.

U.S. Environmental Protection Agency. 1980. Prescribed Procedures for Measurement of Radioactivity in Drinking Water, EPA-600/4-80-32. Washington, DC.

U.S. Environmental Protection Agency. 1988. Contract Laboratory Program Statement of Work for Inorganic Analysis, SOW No. 788, EPA/540/R-94/093. Washington, DC. 
U.S. Environmental Protection Agency. 1994. Contract Laboratory Program Statement of Work for Inorganic Analysis, ILMO 3.0, EPA/540/R-94/076. Washington, DC.

U.S. Environmental Protection Agency. 1995. Contract Laboratory Program Statement of Work for Inorganic Analysis, ILMO 4.0, EPA/540/R-95/121. Washington, DC.

U.S. Environmental Protection Agency. 1996. Test Method for Evaluating Solid Waste Physical/Chemical Methods, SW-846, 3rd Edition. Washington, DC.

U.S. Environmental Protection Agency. 2002. Guidance for Quality Assurance Project Plans, EPA QA/G5. Washington, DC.

U.S. Environmental Protection Agency. 2004. Region 9 Preliminary Remediation Goals (PRGs). As accessed at http://www.epa.gov/region09/waste/sfund/prg/index.htm on 10 November 2006. Prepared by S.J. Smucker. San Francisco, CA.

U.S. Environmental Protection Agency. 2006. EPA Guidance on Systematic Planning Using the Data Quality Objectives Process, EPA QA/G-4. Washington, DC. 


\section{Appendix A}

\section{Project Organization}




\section{A.1.0 Project Organization}

The NNSA/NSO Federal Sub-Project Director for the Industrial Sites Project is Kevin Cabble, who can be contacted at (702) 295-5000. The NNSA/NSO Task Manager is Peter Sanders, who can be reached at (702) 295-1037.

The identification of the project Health and Safety Officer and the Quality Assurance Officer can be found in the appropriate plan. However, personnel are subject to change and it is suggested that the NNSA/NSO Environmental Restoration Federal Project Director be contacted for further

information. The Task Manager will be identified in the FFACO Monthly Activity Report before the start of field activities. 


\section{Appendix B}

\section{Data Quality Objectives Process}




\section{B.1.0 Introduction}

This appendix describes the DQO process that is a seven-step strategic systematic method used to plan data collection activities and define performance criteria for the CAU 124, Storage Tanks, field investigation. The DQOs are designed to ensure that data collected will provide sufficient and reliable information to determine appropriate corrective actions, verify adequacy of existing information, provide sufficient data to implement the corrective actions, and verify closure.

The CAU 124 investigation will be based on the DQOs presented in this appendix as developed by NDEP and NNSA/NSO representatives. The seven steps of the DQO process presented in Sections B.2.0 through B.8.0 were developed in accordance with EPA Guidance on Systematic Planning Using the Data Quality Objectives Process (EPA, 2006) and the CAS-specific information presented in Section B.2.0.

This DQO process presents a judgmental sampling approach for CAU 124 CASs. In general, the procedures used in the DQO process provide:

- A method to establish performance or acceptance criteria that serve as the basis for designing a plan for collecting data of sufficient quality and quantity to support the goals of a study.

- Criteria that will be used to establish the final data collection design such as:

- The nature of the problem that has initiated the study and a CSM of the environmental hazard to be investigated.

- The decisions or estimates that need to be made and the order of priority for resolving them.

- The type of data needed.

- An analytic approach or decision rule that defines the logic for how the data will be used to draw conclusions from the study findings.

- Acceptable quantitative criteria on the quality and quantity of data to be collected, relative to the ultimate use of the data.

- A data collection design that will generate data meeting the quantitative and qualitative criteria specified. A data collection design specifies the type, number, location, and physical 
quantity of samples and data, as well as QA/QC activities that will ensure sampling design and measurement errors are managed sufficiently to meet the performance or acceptance criteria specified in the DQOs. 


\section{B.2.0 Step 1 - State the Problem}

Step 1 of the DQO process defines the problem that requires study; identifies the planning team, and develops a conceptual model of the environmental hazard to be investigated.

As a result of activities associated with each CAU 124 CAS, potentially hazardous and/or radioactive constituents may be present at concentrations that could potentially pose a threat to human health and the environment.

The problem statement for the CAU 124 CASs is: "Existing information on the nature and extent of potential contamination is insufficient to evaluate and confirm closure of the CAU 124 CASs.”

\section{B.2.1 Planning Team Members}

The DQO planning team consists of representatives from NDEP, NNSA/NSO, Stoller-Navarro Joint Venture, and National Security Technologies, LLC. The primary decision-makers are NDEP and NNSA/NSO representatives.

\section{B.2.2 Conceptual Site Model}

The CSM is used to organize and communicate information about site characteristics. It reflects the best interpretation of available information at any time. The CSM is a primary vehicle for communicating assumptions about release mechanisms, potential direction of migration pathways, or specific constraints. It provides a summary of how and where contaminants are expected to move and what impacts such movement may have. It is the basis for assessing how contaminants could reach receptors in the present and future. The CSM describes the most probable scenario for current conditions at CAU 124 CASs and defines the assumptions that are the basis for identifying appropriate sampling strategy and data collection methods. Accurate CSMs are important as they serve as the basis for all subsequent inputs and decisions throughout the DQO process.

The CSM was developed for CAU 124 using information from the physical setting, potential contaminant sources, release information, historical background information, knowledge from similar sites, and physical and chemical properties of the potentially affected media and COPCs. 
The CSM consists of:

- Potential contaminant releases including media subsequently affected.

- Release mechanisms (the conditions associated with the release).

- Potential contaminant source characteristics including contaminants suspected to be present and contaminant-specific properties.

- Site characteristics including physical, topographical, and meteorological information.

- Migration pathways and transport mechanisms that describe the potential for migration and direction to where the contamination may be transported.

- The locations of points of exposure where individuals or populations may come in contact with a COC associated with a CAS.

- $\quad$ Routes of exposure where contaminants may enter the receptor.

If additional elements are identified during the investigation that are outside the scope of the CSM, the situation will be reviewed and a recommendation made as to how to proceed. In such cases, NDEP and NNSA/NSO will be notified and given the opportunity to comment on, and concur with the recommendation.

The applicability of the CSM to each CAS is summarized in Figure B.2-1 and discussed below. Table B.2-1 provides information on CSM elements that will be used throughout the remaining steps of the DQO process. Figure B.2-2 represents site conditions applicable to this CSM. 


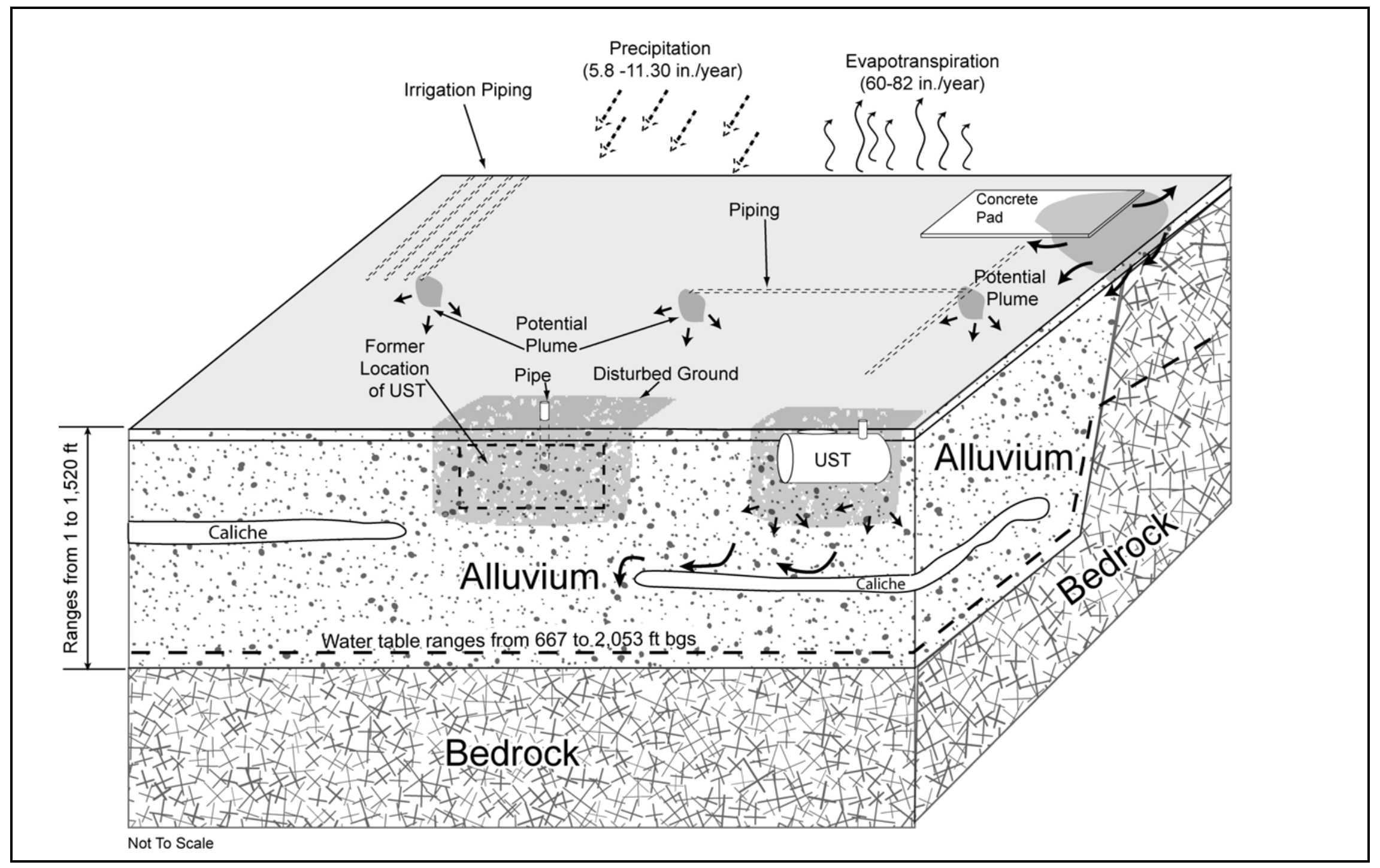

Figure B.2-1

Conceptual Site Model for CAU 124 CASs 
Table B.2-1

Conceptual Site Model

Description of Elements for Each CAU 124 CAS

(Page 1 of 2)

\begin{tabular}{|c|c|c|c|c|c|}
\hline CAS Identifier & $08-02-01$ & $15-02-01$ & $16-02-03$ & $16-02-04$ & $16-99-04$ \\
\hline CAS Description & $\begin{array}{l}\text { Underground } \\
\text { Storage Tank }\end{array}$ & Irrigation Piping & $\begin{array}{l}\text { Underground } \\
\text { Storage Tank }\end{array}$ & Fuel Oil Piping & $\begin{array}{l}\text { Fuel Line (Buried) } \\
\text { and UST }\end{array}$ \\
\hline Site Status & $\begin{array}{l}\text { Inactive and } \\
\text { abandoned }\end{array}$ & $\begin{array}{l}\text { Inactive and } \\
\text { abandoned }\end{array}$ & $\begin{array}{l}\text { Inactive and } \\
\text { abandoned }\end{array}$ & $\begin{array}{l}\text { Inactive and } \\
\text { abandoned }\end{array}$ & Inactive and abandoned \\
\hline Exposure Scenario & Occasional Use Area & Occasional Use Area & Occasional Use Area & Occasional Use Area & Occasional Use Area \\
\hline $\begin{array}{l}\text { Sources of Potential Soil } \\
\text { Contamination }\end{array}$ & $\begin{array}{c}\text { Releases associated } \\
\text { with the contents of } \\
\text { UST }\end{array}$ & $\begin{array}{l}\text { Release associated } \\
\text { with radionuclides } \\
\text { mixed with the water } \\
\text { in reservoir. } \\
\text { Releases associated } \\
\text { with direct spray of } \\
\text { radionuclide. } \\
\text { Release associated } \\
\text { with use of metals for } \\
\text { scientific testing. } \\
\text { Releases associated } \\
\text { with storage of } \\
\text { chemicals in the } \\
\text { former storage shed. }\end{array}$ & $\begin{array}{c}\text { Releases associated } \\
\text { with the contents of } \\
\text { UST and associated } \\
\text { piping }\end{array}$ & $\begin{array}{l}\text { Release associated } \\
\text { with fuel oil piping }\end{array}$ & $\begin{array}{l}\text { Releases associated with } \\
\text { the contents of UST and } \\
\text { associated piping }\end{array}$ \\
\hline $\begin{array}{l}\text { Location of Contamination/ } \\
\text { Release Point }\end{array}$ & $\begin{array}{c}\text { Surface and } \\
\text { subsurface soil at or } \\
\text { near UST }\end{array}$ & $\begin{array}{c}\text { Surface and } \\
\text { subsurface soil at or in } \\
\text { the fenced area plots. } \\
\text { Area around/ adjacent } \\
\text { to the concrete } \\
\text { storage shed pad. }\end{array}$ & $\begin{array}{c}\text { Surface and } \\
\text { subsurface soil at or } \\
\text { near UST }\end{array}$ & $\begin{array}{c}\text { Surface and } \\
\text { subsurface soil } \\
\text { around and under } \\
\text { piping main } \\
\text { connections and ends }\end{array}$ & $\begin{array}{l}\text { Surface and subsurface } \\
\text { soil at or near UST. } \\
\text { Surface and subsurface at } \\
\text { ends of pipe. }\end{array}$ \\
\hline Amount Released & Unknown & Unknown & Unknown & Unknown & Unknown \\
\hline Affected Media & $\begin{array}{l}\text { Surface and shallow } \\
\text { subsurface soil }\end{array}$ & $\begin{array}{l}\text { Surface and shallow } \\
\text { subsurface soil }\end{array}$ & $\begin{array}{l}\text { Surface and shallow } \\
\text { subsurface soil }\end{array}$ & $\begin{array}{l}\text { Surface and shallow } \\
\text { subsurface soil }\end{array}$ & $\begin{array}{l}\text { Surface and shallow } \\
\text { subsurface soil }\end{array}$ \\
\hline
\end{tabular}

\section{Uncontrolled When Printed}


Table B.2-1

\section{Conceptual Site Model}

Description of Elements for Each CAU 124 CAS

(Page 2 of 2)

\begin{tabular}{|c|c|c|c|c|c|}
\hline CAS Identifier & $08-02-01$ & $15-02-01$ & $16-02-03$ & $16-02-04$ & $16-99-04$ \\
\hline CAS Description & $\begin{array}{l}\text { Underground } \\
\text { Storage Tank }\end{array}$ & Irrigation Piping & $\begin{array}{l}\text { Underground } \\
\text { Storage Tank }\end{array}$ & Fuel Oil Piping & $\begin{array}{l}\text { Fuel Line (Buried) } \\
\text { and UST }\end{array}$ \\
\hline Potential Contaminants & $\begin{array}{l}\text { TPH-DRO,VOCs, } \\
\text { SVOCs, } \\
\text { Radionuclides, } \\
\text { RCRA Metals, PCBs }\end{array}$ & $\begin{array}{l}\text { Radionuclides to } \\
\text { include tritium, VOCs, } \\
\text { SVOCs, Pesticides, } \\
\text { Herbicides, Metals }\end{array}$ & $\begin{array}{l}\text { TPH-DRO, VOCs, } \\
\text { SVOCs, } \\
\text { Radionuclides, } \\
\text { RCRA Metals, PCBs }\end{array}$ & $\begin{array}{l}\text { TPH-DRO, VOCs, } \\
\text { SVOCs }\end{array}$ & $\begin{array}{l}\text { TPH-DRO/GRO, } \\
\text { VOCs, SVOCs }\end{array}$ \\
\hline Transport Mechanisms & \multicolumn{5}{|c|}{$\begin{array}{l}\text { Percolation of precipitation through subsurface media serves as the major driving force for migration of contaminants. } \\
\text { However, because the arid environment of the NTS, percolation of precipitation is very small and migration of contaminants has } \\
\text { been shown to be limited (USGS, 1995). Evaporation potentials significantly exceed available soil moisture from precipitation } \\
\text { (i.e., } 5.8 \text { to } 11.10 \text { in./yr) (ARL/SORD 2006). Surface water runoff may provide for the transportation of some contaminants } \\
\text { inside or outside of the CAS footprints. }\end{array}$} \\
\hline Migration Pathways & \multicolumn{5}{|c|}{$\begin{array}{l}\text { No other migration pathway anticipated other than in soil where it is expected. Vertical transport is expected to dominate over } \\
\text { lateral transport due to small surface gradients. }\end{array}$} \\
\hline $\begin{array}{l}\text { Lateral and Vertical Extent } \\
\text { of Contamination }\end{array}$ & \multicolumn{5}{|c|}{$\begin{array}{l}\text { Contamination, if present, is expected to be contiguous to the release points. Concentrations are expected to decrease with } \\
\text { distance and depth from the source. Groundwater contamination is not expected. Groundwater flows from the northwest to the } \\
\text { southeast ranging in depth from } 667 \mathrm{ft} \text { bgs in Area 8, 2,053 ft bgs in Area 15, and } 750 \mathrm{ft} \text { bgs in Area } 16 \text {. Surface migration may } \\
\text { occur as a result of runoff. }\end{array}$} \\
\hline Exposure Pathways & \multicolumn{5}{|c|}{$\begin{array}{l}\text { The potential for contamination exposure is limited to industrial and construction workers, and military personnel conducting } \\
\text { training. These human receptors may be exposed to COPCs through oral ingestion, inhalation, dermal contact (absorption) of } \\
\text { soil and/or debris due to inadvertent disturbance of these materials or irradiation by radioactive materials. }\end{array}$} \\
\hline
\end{tabular}

AST = Aboveground storage tank bgs = Below ground surface $\mathrm{COC}=$ Contaminant of concern

COPC $=$ Contaminant of potential concern

$\mathrm{DRO}=$ Diesel-range organics

$\mathrm{ft}=$ Foot

$\mathrm{GRO}=$ Gasoline-range organics in./yr = Inches per year

NTS = Nevada Test Site

RCRA = Resource Conservation and Recovery Act

SVOC $=$ Semivolatile organic compound

$\mathrm{TPH}=$ Total petroleum hydrocarbons

UST = Underground storage tank

VOC $=$ Volatile organic compound 


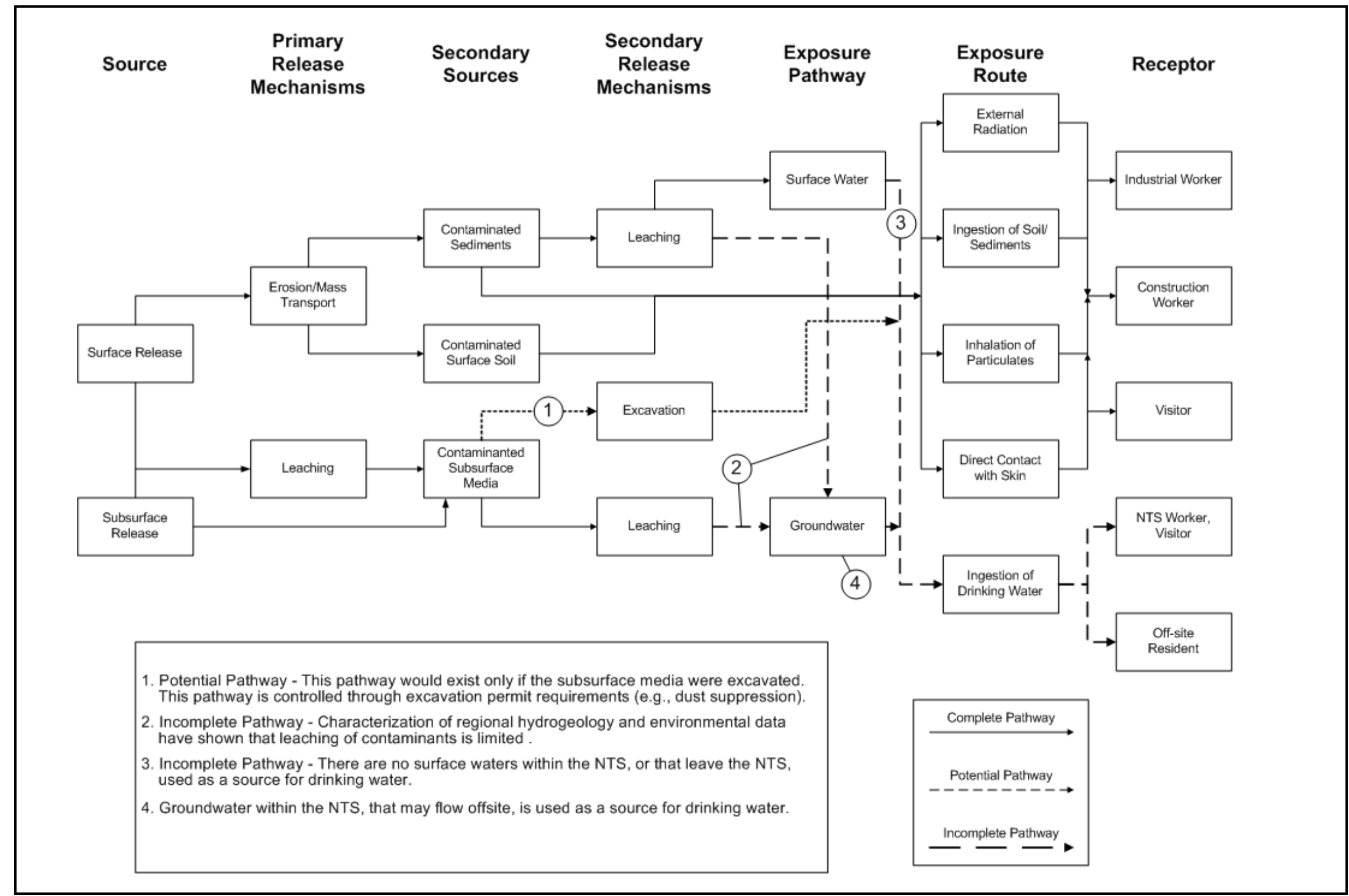

Figure B.2-2

Conceptual Site Model Diagram for CAU 124 CASs 


\section{B.2.2.1 Contaminant Release}

The likely locations of the contamination and releases to the environment are the soils directly below and/or adjacent to the CSM surface and subsurface components (i.e., underground storage tanks, associated underground piping). The CSM accounts for potential releases resulting from overflow of system components that were present at the ground surface and/or from migration away from the sites of releases that are present at the ground surface.

\section{B.2.2.2 Potential Contaminants}

Contaminants of potential concern were identified during the planning process through the review of site history, process knowledge, personal interviews, past investigation efforts (where available), and inferred activities associated with the CASs. Because complete information regarding activities performed at the CAU 124 CASs is not available, contaminants detected at similar NTS sites were included in the contaminant lists to reduce uncertainty. The list of COPCs is intended to encompass the contaminants that could potentially be present at each CAS. The COPCs applicable to Decision I environmental samples from each CAU 124 CAS are defined as the constituents reported from the analytical methods stipulated in Table B.2-2.

During the review of site history documentation, process knowledge information, personal interviews, past investigation efforts (where available), and inferred activities associated with the CASs, some of the COPCs were identified as targeted contaminants at specific CASs. Targeted contaminants are those COPCs for which evidence in the available site and process information suggests that they may be reasonably suspected to be present at a given CAS. The targeted contaminants are required to meet a more stringent completeness criteria than other COPCs, thus providing greater protection against a decision error (see Section B.2.2). Targeted contaminants for each CAU 124 CAS are identified in Table B.2-3. 
Table B.2-2

Analytical Program ${ }^{a}$

(Includes Waste Characterization Analyses)

\begin{tabular}{|c|c|c|c|c|c|}
\hline Analyses $^{b}$ & 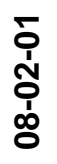 & 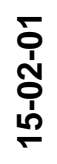 & 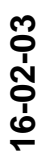 & 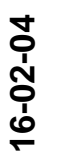 & $\begin{array}{l}\text { ठ } \\
\text { த் } \\
\text { ọ } \\
\dot{d}\end{array}$ \\
\hline \multicolumn{6}{|c|}{ Organic COPCs } \\
\hline Total Petroleum Hydrocarbons-Diesel-Range Organics & $\mathrm{x}$ & & $\mathrm{x}$ & $\mathrm{X}$ & $\mathrm{X}$ \\
\hline Total Petroleum Hydrocarbons-Gasoline-Range Organics & & & & & $\mathrm{X}$ \\
\hline Polychlorinated Biphenyls & $\mathrm{X}$ & & $\mathrm{X}$ & & \\
\hline Semivolatile Organic Compounds ${ }^{c}$ & $X$ & $\mathrm{X}$ & $x$ & $\mathrm{X}$ & $\mathrm{X}$ \\
\hline Volatile Organic Compounds ${ }^{c}$ & $x$ & $x$ & $\mathrm{x}$ & $\mathrm{X}$ & $\mathrm{X}$ \\
\hline Pesticides $^{c}$ & & $x$ & & & \\
\hline Herbicides $^{c}$ & & $x$ & & & \\
\hline \multicolumn{6}{|c|}{ Inorganic COPCs } \\
\hline Total Resource Conservation and Recovery Act Metals ${ }^{c}$ & $x$ & $\mathrm{X}$ & $\mathrm{x}$ & & \\
\hline \multicolumn{6}{|c|}{ Radionuclide COPCs } \\
\hline Gamma Spectroscopy $^{d}$ & $\mathrm{X}$ & $\mathrm{X}$ & $x$ & & \\
\hline \multicolumn{6}{|l|}{ Isotopic Uranium } \\
\hline \multicolumn{6}{|l|}{ Isotopic Plutonium } \\
\hline \multicolumn{6}{|l|}{ Strontium-90 } \\
\hline Tritium & & $x$ & & & \\
\hline \multicolumn{6}{|c|}{ Waste Characterization Analyses } \\
\hline Gross Alpha/Beta (Aqueous only) & $\mathrm{X}$ & $\mathrm{X}$ & $\mathrm{X}$ & $\mathrm{X}$ & $X$ \\
\hline Tritium & $\mathrm{X}$ & $\mathrm{X}$ & $x$ & $\mathrm{X}$ & $\mathrm{X}$ \\
\hline Gamma Spectroscopye & $\mathrm{X}$ & $\mathrm{X}$ & $x$ & $\mathrm{X}$ & $\mathrm{X}$ \\
\hline Isotopic Uraniume & $x$ & $x$ & $x$ & $\mathrm{X}$ & $\mathrm{X}$ \\
\hline Isotopic Plutonium ${ }^{\mathrm{e}}$ & $x$ & $x$ & $x$ & $\mathrm{X}$ & $\mathrm{x}$ \\
\hline Strontium-90 & $x$ & $x$ & $x$ & $\mathrm{X}$ & $x$ \\
\hline
\end{tabular}

${ }^{a}$ The COPCs are the analytes reported from the analytical methods listed.

bIf the volume of material is limited, prioritization of the analyses will be necessary.

'May also include Toxicity Characteristic Leaching Procedure analytes if sample is collected for waste management purposes.

${ }^{\mathrm{d}}$ Results of gamma analysis will be used to determine if further radioanalytical analysis is warranted.

eOnly required to collect if physically solid waste is generated that has the potential constituent.

COPC $=$ Contaminant of potential concern

$\mathrm{X}=$ Required analytical method 
Table B.2-3

Targeted Contaminants for CAU $124^{\mathrm{a}}$

\begin{tabular}{||c|c|c||}
\hline Corrective Action Site & $\begin{array}{c}\text { Chemical Targeted } \\
\text { Contaminant(s) }\end{array}$ & $\begin{array}{c}\text { Radiological Targeted } \\
\text { Contaminant(s) }\end{array}$ \\
\hline \hline $08-02-01$ & None & None \\
\hline $15-02-01$ & None & None \\
\hline $16-02-03$ & None & None \\
\hline $16-02-04$ & TPH-DRO & None \\
\hline $16-99-04$ & TPH-DRO & None \\
\hline
\end{tabular}

alf a COPC is detected at a concentration exceeding the action level, it will be identified as a target analyte. blodine-131, although used at the EPA Farm, is not considered a target analyte due to its extremely short half-life of 8.01 days.

COPC $=$ Contaminant of potential concern

$\mathrm{DRO}=$ Diesel-range organics

$\mathrm{TPH}=$ Total petroleum hydrocarbons

\section{B.2.2.3 Contaminant Characteristics}

Contaminant characteristics include, but are not limited to: solubility, density, and adsorption potential. In general, contaminants with large particle size, low solubility, high affinity for media, and/or high density can be expected to be found relatively close to release points. Contaminants with small particle size, high solubility, low affinity for media, and/or low density are found further from release points or in low areas where evaporation or ponding will concentrate dissolved constituents. Volatile COPCs may impact the air, and COPCs contained in a liquid media or are “dusts” dissolved by rainwater may infiltrate the subsoil and potentially impact groundwater. The COPCs that volatilize, such as VOCs, are not an anticipated concern at these CASs because of the age of the releases; therefore, if they were present in the past, they would be depleted over time. Infiltration of any COPC, beyond shallow soil, is not a concern at these sites as discussed in the groundwater impacts section.

\section{B.2.2.4 Site Characteristics}

Site characteristics are defined by the interaction of physical, topographical, and meteorological attributes and properties. Physical properties include permeability, porosity, hydraulic conductivity, degree of saturation, sorting, chemical composition, and organic content. Topographical and meteorological properties and attributes include slope stability, precipitation frequency, amounts, and runoff pathways; drainage channels and ephemeral streams, and evapotranspiration potential. 
The NTS lies in the southern part of the Great Basin section of the Basin and Range physiographic province (USGS, 1995). The topography of this province consists of numerous north-south trending, linear mountain ranges separated by broad, flat-floored and gently-sloped valleys.

The general geology of the NTS consists of the following geologic units. The oldest units are complexly folded and faulted Paleozoic units composed mainly of carbonate rocks (limestone and dolomite) separated by a middle section of siliciclastic rocks (shale and quartzite). Tertiary-age volcanic tuff and lava overlay the Paleozoic units in many places. The valleys are covered with Tertiary and Quaternary-age alluvial and colluvial deposits that have eroded from the surrounding mountain ranges (ERDA, 1977).

The structural geology of the NTS is complex. Thousands of normal faults lie within the area and are responsible for the main characteristics of the Basin and Range topography (Winograd and Thordarson, 1975). Along with normal faults, strike-slip faults and shear zones cut and offset thrust faults in several places on the NTS. The complexity of the structural geology may influence the regional movement of groundwater (LLNL, 1982; Winograd and Thordarson, 1975).

Groundwater is not expected to be impacted in Areas 8,15, and 16 of the NTS, because infiltration of precipitation through subsurface media typically serves as the major driving force for migration of contaminants. Because of the arid environment of the NTS, percolation of precipitation is small, and migration of contaminants has been shown to be limited. Evaporation potentials at the NTS range between 60 to 82 inches per year (in./yr), significantly exceeding the NTS average precipitation. The average precipitation across the CAU 124 sites ranges from 5.80 to 11.30 in./yr (ARL/SORD, 2006).

\section{B.2.2.5 Migration Pathways and Transport Mechanisms}

Migration pathways of potential contaminants include the lateral migration across surface soils/sediments and vertical migration of potential contaminants into and through subsurface soils. An important CSM element in developing a sampling strategy is the expected fate and transport of contaminants (how contaminants migrate through media and where they can be expected in the environment). Fate and transport of contaminants are presented in the CSM as the migration pathways and transport mechanism that could potentially move the contaminants throughout the 
various media. Fate and transport are influenced by physical and chemical characteristics of the contaminants and media described in Sections B.2.2.3 and B.2.2.4.

Infiltration and percolation of precipitation serves as a driving force for downward migration of contaminants. However, due to the high potential evapotranspiration and the limited precipitation at the CASs, percolation of infiltrated precipitation at the NTS does not provide a significant mechanism for contaminants to impact groundwater (DOE/NV, 1992).

Contaminants can be expected to be found relatively close to release points or in low areas where settling may occur and evaporation will concentrate the constituents of concern. Given the relatively low surficial contouring of these CASs, lateral migration of potential COPCs of any major distance is unlikely. Also, because of the expected limited mobility, the affected media is typically the surface and shallow subsurface soil. Concentrations are expected to decrease with horizontal and vertical distance from the source.

Infiltration of COPCs beyond shallow subsurface soil is not a concern at these CASs. While contaminants within a weathered hydrocarbon spill/release may cover a visible area, they tend to be present in higher concentrations near the point of discharge and decrease with increased distance from the point of discharge, both laterally and vertically. For example, petroleum-based fuels in soil tend to be found in higher concentrations near the surface shortly after the spill/leak, then decrease as environmental processes work to reduce the concentrations where such factors as volatilization, microbial degradation, and photodegradation are most effective (i.e., at the surface). Just below the surface, these environmental processes are retarded, thereby resulting in less natural attenuation and greater residual concentration. Other factors such as adsorption to soil particles and vertical transport with precipitation also enhance the hydrocarbon concentrations within the shallow subsurface. Sampling in these preferential locations will increase the probability of detecting contamination if it is present anywhere within the CAS boundary.

\section{B.2.2.6 Exposure Scenarios}

Human receptors may be exposed to COPCs through oral ingestion, inhalation, dermal contact (absorption) of soil or debris due to inadvertent disturbance of these materials or irradiation by radioactive materials. The land-use and exposure scenarios for the CAU 124 CASs are listed in 
Table B.2-4. These are based on NTS current and future land use (DOE/NV, 1998). Although all CASs are located in areas where former structures exist from past activities, no facilities are present to allow these CASs to be used as an assigned work station for NTS site personnel, and these CASs are at remote locations without site improvements, and where no regular work is performed. There is still the possibility, however, that site workers could occupy these locations on an occasional and temporary basis such as a military exercise or emergency preparedness training. Therefore, these sites are classified as occasional work areas.

Table B.2-4

Land-Use and Exposure Scenarios

\begin{tabular}{||c|l|l||}
\hline $\begin{array}{c}\text { Corrective } \\
\text { Action Site }\end{array}$ & \multicolumn{1}{|c|}{ Record of Decision Land-Use Zone } & \multicolumn{1}{|c|}{ Exposure Scenario } \\
\hline \hline 08-02-01 & $\begin{array}{l}\text { Nuclear Test Zone } \\
\text { This area is reserved for dynamic experiments, } \\
\text { hydrodynamic tests, and underground nuclear } \\
\text { weapons and weapons effects tests. This zone } \\
\text { includes compatible defense and nondefense } \\
\text { research, development, and testing activities. }\end{array}$ & $\begin{array}{l}\text { Occasional Use Area } \\
\text { Worker will be exposed to the site occasionally } \\
\text { (up to } 80 \text { hours per year for } 5 \text { years). Site } \\
\text { structures are not present for shelter and } \\
\text { comfort of the worker. }\end{array}$ \\
\hline 15-02-01 & $\begin{array}{l}\text { Reserved Zone (Within Nevada Test Site) } \\
\text { This area includes land and facilities that provide } \\
\text { widespread flexible support for diverse short-term } \\
\text { testing and experimentation. The reserved zone is } \\
\text { also used for short duration exercises and training } \\
\text { such as nuclear emergency response and Federal } \\
\text { Radiological Monitoring and Assessment Center } \\
\text { training and U.S. Department of Defense } \\
\text { land-navigation exercises and training. }\end{array}$ & $\begin{array}{l}\text { Worker will be exposed to the site occasionally } \\
\text { (up to 80 hours per year for } 5 \text { years). Site } \\
\text { structures are not present for shelter and } \\
\text { comfort of the worker. }\end{array}$ \\
\hline $\begin{array}{l}\text { Occasional Use Area } \\
16-02-03 \\
16-99-04\end{array}$ & $\begin{array}{l}\text { Nuclear and High Explosives Test Zone } \\
\text { This area is designated within the Nuclear Test Zone } \\
\text { for additional underground nuclear weapons tests and } \\
\text { outdoor high explosive tests. This zone includes } \\
\text { compatible defense and nondefense research, } \\
\text { development, and testing activities. }\end{array}$ & $\begin{array}{l}\text { Occasional Use Area } \\
\text { Worker will be exposed to the site occasionally } \\
\text { (up to 80 hours per year for } 5 \text { years). Site } \\
\text { structures are not present for shelter and } \\
\text { comfort of the worker. }\end{array}$ \\
\hline
\end{tabular}

The defined land-use zones at the NTS (DOE/NV, 1998) for the CAU 124 CASs specify future land uses that are consistent with current land uses. The nature of the future land-use zones precludes the presence of site workers except on an occasional or temporay basis during testing activities. The future land-use zones and exposure scenarios for CAU 124 are described in Table B.2-4. 


\section{B.3.0 Step 2 - Identify the Goal of the Study}

Step 2 of the DQO process states how environmental data will be used in meeting objectives and solving the problem, identifies study questions or decision statement(s), and considers alternative outcomes or actions that can occur upon answering the question(s). Figure B.3-1 depicts the sequential flow of questions, answers, and action alternatives required to fulfill the objectives of the SAFER process.

\section{B.3.1 Decision Statements}

The Decision I statement is: “Is any COC present in environmental media within the CAS?” For judgmental sampling design, any analytical result for a COPC above the FAL will result in that COPC being designated as a COC. A COC may also be defined as a contaminant that, in combination with other like contaminants, is determined to jointly pose an unacceptable risk based on a multiple constituent analysis (NNSA/NSO, 2006). If a COC is detected, then Decision II must be resolved.

The Decision II statement is: "If a COC is present, is sufficient information available to meet the closure objectives?” Sufficient information is defined to include:

- Identifying the volume of media containing a COC bounded by analytical sample results in lateral and vertical directions.

- The information needed to characterize IDW for disposal.

- Information necessary to select the appropriate corrective action to complete site closure. A corrective action will be determined for sites containing a COC. The evaluation of the need for corrective action will include the potential for wastes present at a site to cause future contamination of site environmental media, if the wastes were released. 


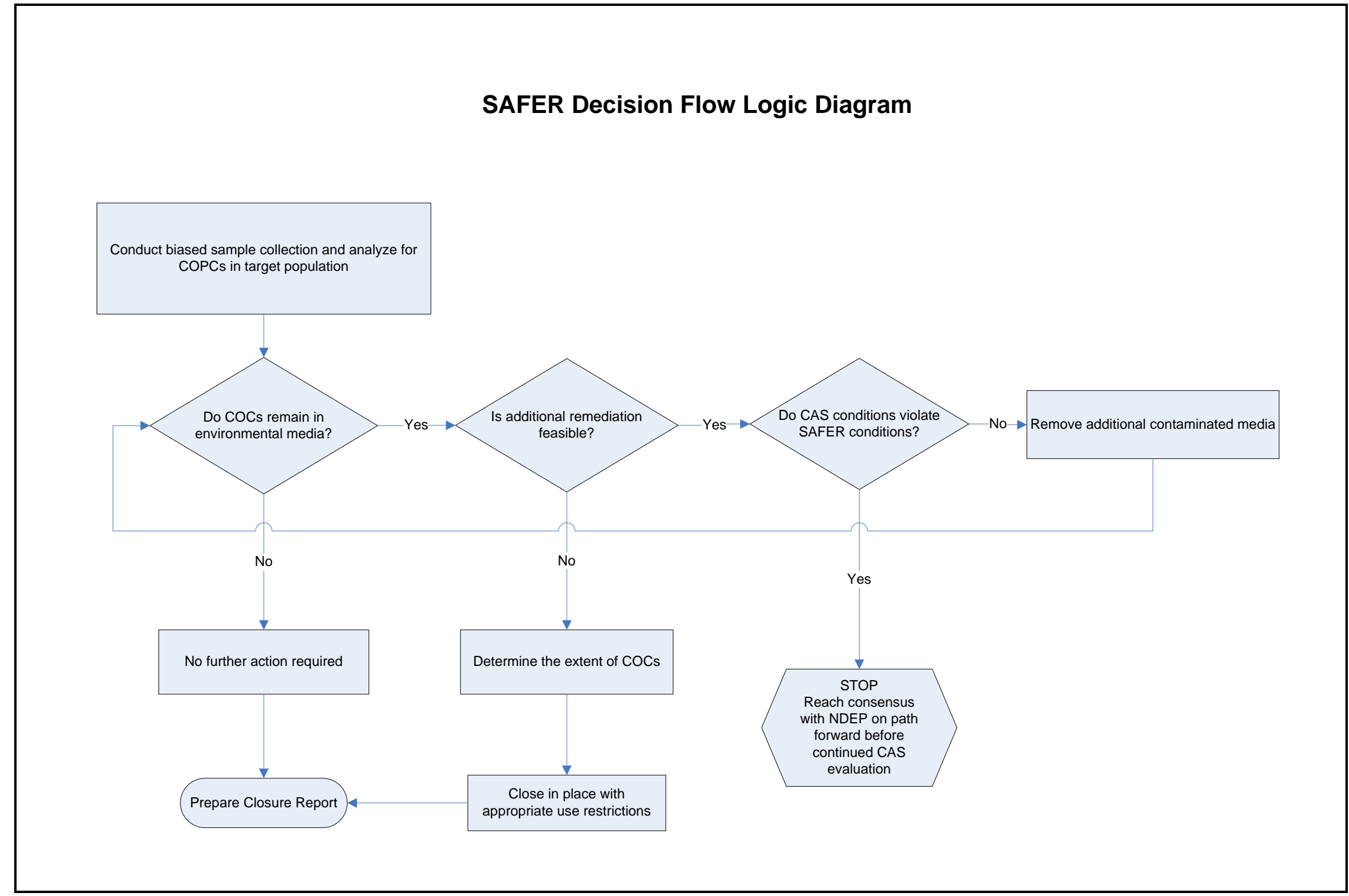

Figure B.3-1

SAFER Closure Decision Process for CAU 124 
If sufficient information is not available to meet the closure objectives, then site conditions will be re-evaluated and additional samples collected (as long as the scope of the investigation is not exceeded and no CSM assumption is proven incorrect).

\section{B.3.2 Alternative Actions to the Decisions}

In this section, the alternative actions are identified that may be taken to solve the problem depending on the possible investigation outcomes.

\section{B.3.2.1 Alternative Actions to Decision I}

If no COC associated with a release from the CAS is detected, then further assessment of the CAS is not required, and the corrective action alternative of no further action will be selected. If a COC associated with a release from the CAS is detected, then additional sampling will be conducted to determine the extent of COC contamination. If the extent of the contamination is defined, and additional remediation is feasible, then clean close the site by removing the contaminated media. If the extent of contamination has been determined, and additional remediation is not feasible, then the extent of contamination will be defined and the contaminated area will be closed in place with appropriate use restrictions.

If the collection of verification samples confirm that contaminated media has been removed, then the clean closure objectives will have been met. If contamination still exists and additional remediation would violate the conditions of the SAFER, then work will stop and a consensus reached with NDEP on the path forward before continuing the CAS investigation.

\section{B.3.2.2 Alternative Actions to Decision II}

If sufficient information is available to define the extent of COC contamination, and confirm that closure objectives were met, then no further CAS assessment is required. If sufficient information is not available to define the extent of contamination, or confirm that closure objectives were met, then additional samples will be collected until the extent is defined. 


\section{B.4.0 Step 3 - Identify Information Inputs}

Step 3 of the DQO process identifies the information needed, determines information sources, and identifies sampling and analysis methods that will allow reliable comparisons with FALs.

\section{B.4.1 Information Needs}

To resolve Decision I (determine whether a COC is present at a given CAS), samples must be collected and analyzed following these two criteria:

- Samples must either (a) be collected in areas most likely to contain a COC (judgmental sampling) or (b) properly represent contamination at the CAS (probabilistic sampling).

- The analytical suite selected must be sufficient to identify any COCs present in the samples.

To resolve Decision II (determine whether sufficient information is available to confirm closure objectives were met at each CAS), samples must be collected and analyzed to meet the following criteria:

- Collection must occur in areas contiguous to the contamination but where contaminant concentrations are below FALs.

- Waste samples or environmental media must provide sufficient information to characterize the IDW for disposal.

- Contaminated environmental media samples must provide sufficient information to determine potential remediation waste types.

- The analytical suites selected must be sufficient to detect COCs at concentrations equal to or less than their corresponding FAL.

\section{B.4.2 Sources of Information}

Information to satisfy Decision I and Decision II will be generated by collecting environmental samples using grab sampling, hand augering, direct push, backhoe excavation, drilling, or other appropriate sampling methods. These samples will be submitted to analytical laboratories that meet the quality criteria stipulated in the Industrial Sites QAPP (NNSA/NV, 2002a). Only validated data 
from analytical laboratories will be used to make DQO decisions. Sample collection and handling activities will follow standard procedures.

\section{B.4.2.1 Sample Locations}

Design of the sampling approach for the CAU 124 CASs must ensure that the data collected are sufficient for selection of the appropriate corrective action (EPA, 2002). To meet this objective, the samples collected from each site should be from locations most likely to contain a COC, if present (judgmental). These sample locations, therefore, can be selected by means of biasing factors used in judgmental sampling (e.g., a stain likely to contain a spilled substance). The implementation of a judgmental approach for the selection of sample locations are discussed in the following sections.

Decision I sample locations at CAU 124 CASs will be determined based upon the likelihood of the soil containing a COC, if present at the CAS. These locations will be selected based on field-screening techniques, biasing factors, the CSM, and existing information. Analytical suites for Decision I samples will include the COPCs identified in Table B.2-2.

Field-screening techniques may be used to select appropriate sampling locations by providing semiquantitative data that can be used to comparatively select samples to be submitted for laboratory analyses from several screening locations. Field screening also may be used for health and safety monitoring and to assist in certain health and safety decision-making. The following field-screening methods and biasing factors may be used to select biased sample locations at CAU 124:

- Walkover surface area radiological surveys - A radiological survey instrument may be used to detect locations of elevated radioactivity of radiological contamination, as permitted by terrain and field conditions.

- Documented process knowledge on source and location of release (e.g., volume of release).

- Stains - A spot or area on the soil surface that may indicate the presence of a potentially hazardous liquid. Typically, stains indicate an organic liquid, such as an oil, has reached the soil and may have spread vertically and horizontally.

- Geophysical anomalies - A location identified during geophysical surveys that had results indicating surface or subsurface materials existed and were not consistent with the natural surroundings (e.g., buried concrete or metal, surface metallic objects). 
- Drums, containers, equipment or debris - Materials that may have been used, or added to, a location, and that may have contained or come in contact with, hazardous or radioactive substances at some point during use.

- Lithology - Locations where variations in lithology (soil or rock) indicate different conditions or materials exist.

- Preselected areas based on process knowledge of the site - Locations for which evidence such as historical photographs, experience from previous investigations, or interviewee's input, exists that a release of hazardous or radioactive substances may have occurred.

- Preselected areas based on process knowledge of the contaminant(s) - Locations that may reasonably have received contamination, selected on the basis of the chemical and/or physical properties of the contaminant(s) in that environmental setting.

- Experience and data from investigations of similar sites.

- Visual indicators such as discoloration, textural discontinuities, disturbance of native soils, or other indication of potential contamination.

- Presence of debris, waste, or equipment.

- Odor.

- Physical and chemical characteristics of contaminants.

- Other biasing factors: Factors not previously defined for the CAI but that become evident once the site investigation begins.

Decision II sample step-out locations will be selected based on the CSM, biasing factors, and existing data. Analytical suites will include those parameters that exceeded FALs (i.e., COCs) in prior samples. Biasing factors to support Decision II sample locations include Decision I biasing factors plus available analytical results.

\section{B.4.2.2 Analytical Methods}

Analytical methods are available to provide the data needed to resolve the decision statements. The analytical methods and laboratory requirements (e.g., detection limits, precision, and accuracy) are provided in Tables 3-4 and B.2-3. 


\section{B.5.0 Step 4 - Define the Boundaries of the Study}

Step 4 of the DQO process defines the target population of interest and relevant spatial boundaries, specifies temporal and other practical constraints associated with sample/data collection, and defines the sampling units on which decisions or estimates will be made.

\section{B.5.1 Target Populations of Interest}

The population of interest to resolve Decision I ("Is any COC present in environmental media within the CAS?”) is any location within the site that is contaminated with any contaminant above a FAL (judgmental sampling. The populations of interest to resolve Decision II ("If a COC is present, is sufficient information available to evaluate potential corrective action alternatives?”) are:

- Each one of a set of locations bounding contamination in lateral and vertical directions.

- Environmental media or IDW that must be characterized for disposal.

- $\quad$ Potential remediation waste.

- Environmental media where natural attenuation or biodegradation or construction/evaluation of barriers is considered.

\section{B.5.2 Spatial Boundaries}

Spatial boundaries are the maximum lateral and vertical extent of expected contamination at each CAS, as shown in Table B.5-1. Contamination found beyond these boundaries may indicate a flaw in the CSM and may require re-evaluation of the CSM before the investigation continues. Each CAS is considered geographically independent and intrusive activities are not intended to extend into the boundaries of neighboring CASs.

\section{B.5.3 Practical Constraints}

Practical constraints such as military activities at the NTS, weather (i.e., high winds, rain, lightning, extreme heat), utilities, threatened or endangered animal and plants, unstable or steep terrain, and/or access restrictions may affect the ability to investigate this site. The practical constraints associated with the investigation of the CAU 124 CASs are summarized in Table B.5-2. 
Table B.5-1

Spatial Boundaries of CAU 124 CASs

\begin{tabular}{|c|l|}
\hline Corrective Action Site & \multicolumn{1}{|c|}{ Spatial Boundaries } \\
\hline \hline $08-02-01$ & $\begin{array}{l}\text { The footprint of the CAS }(\sim 30 \times 40 \text { feet [ft]) plus a 30-ft lateral } \\
\text { buffer; } 20 \mathrm{ft} \text { below ground surface (bgs) vertically. }\end{array}$ \\
\hline $15-02-01$ & $\begin{array}{l}\text { The footprint of Plot A }(\sim 960 \times 720 \mathrm{ft}) \text { and Plot B }(\sim 430 \times 225 \mathrm{ft}) \\
\text { plus a 150-ft lateral buffer; } 20 \mathrm{ft} \text { bgs vertically; } 20-\mathrm{ft} \text { lateral buffer } \\
\text { outside reservoir berms. }\end{array}$ \\
\hline $16-02-03$ & $\begin{array}{l}\text { The footprint of the CAS }(\sim 90 \times 70 \mathrm{ft}) \text { plus a 75-ft lateral buffer; } \\
20 \mathrm{ft} \text { bgs vertically. }\end{array}$ \\
\hline $16-02-04$ & $\begin{array}{l}\text { The footprint of the CAS }(\sim 630 \times 360 \mathrm{ft}) \text { plus a 200-ft lateral } \\
\text { buffer; } 20 \mathrm{ft} \text { bgs vertically. }\end{array}$ \\
\hline $16-99-04$ & $\begin{array}{l}\text { The footprint of the CAS }(\sim 27 \times 18 \mathrm{ft}) \text { plus a 200-ft lateral buffer; } \\
20 \mathrm{ft} \text { bgs vertically (combined with CAS 16-02-04). }\end{array}$ \\
\hline
\end{tabular}

Table B.5-2

Practical Constraints for the CAU 124 Field Investigation

\begin{tabular}{||c|l||}
\hline Corrective Action Site & \multicolumn{1}{|c|}{ Practical Constraints } \\
\hline \hline $08-02-01$ & $\begin{array}{l}\text { Weather (i.e., high winds, rain, lightning, extreme heat/cold), } \\
\text { above/underground utilities, potential radiological concern, } \\
\text { loose and unconsolidated terrain. }\end{array}$ \\
\hline $15-02-01$ & $\begin{array}{l}\text { Weather (i.e., high winds, rain, lightning, extreme heat/cold, } \\
\text { above/below ground irrigation lines, concrete pads and water } \\
\text { lines exposed in southeast corner of Plot A; potential } \\
\text { radiological exposure, and loose and unconsolidated terrain. }\end{array}$ \\
\hline $16-02-03$ & $\begin{array}{l}\text { Weather (i.e., high winds, rain, lightning, extreme heat/cold), } \\
\text { restricted access due to NTS activities, above/below ground } \\
\text { utilities, exposed/capped utility stick-ups, and loose and } \\
\text { unconsolidated terrain; access roads unmaintained. }\end{array}$ \\
\hline $16-02-04$ & $\begin{array}{l}\text { Weather (i.e., high winds, rain, lightning, extreme heat/cold), } \\
\text { restricted access due to NTS activities, above/below ground } \\
\text { utilities, several concrete pads with utility sitck-ups throughout } \\
\text { CAS, and loose and unconsolidated terrain; access roads } \\
\text { unmaintained. }\end{array}$ \\
\hline $16-99-04$ & $\begin{array}{l}\text { Weather (i.e., high winds, rain, lightning, extreme heat/cold), } \\
\text { restricted access due to NTS activities, above/below ground } \\
\text { utilities, concrete pads with utility stick-ups, and loose and } \\
\text { unconsolidated terrain; access roads unmaintained. }\end{array}$ \\
\hline
\end{tabular}

NTS $=$ Nevada Test Site 


\section{B.5.4 Define the Sampling Units}

The scale of decision-making in Decision I is defined as the CAS. A COC detected within the CAS will cause the determination that the CAS is contaminated and needs further evaluation. The scale of decision-making for Decision II is defined as a contiguous area contaminated with a COC originating from the CAS. Resolution of Decision II requires this contiguous area to be bounded laterally and vertically. 


\section{B.6.0 Step 5 - Develop the Analytic Approach}

Step 5 of the DQO process specifies appropriate population parameters for decision-making, defines action levels and generates an "If ... then ... else" decision rule that defines the conditions under which possible alternative actions will be chosen. This step also specifies the parameters that characterize the population of interest, the FALs, and confirms that the analytical detection limits are capable of detecting FALs.

\section{B.6.1 Population Parameters}

For judgmental sampling results, the population parameter is the observed concentration of each contaminant from each individual analytical sample. Each sample result will be compared to the FALs to determine the appropriate resolution to Decision I and Decision II. For Decision I, a single sample result for any contaminant exceeding a FAL would cause a determination that a COC is present within the CAS.

For probabilistic sampling results, the population parameter is the upper confidence limit (UCL) of the sample population average concentration, of each detected contaminant from all analytical samples, from an individual contaminant release. The population parameter will be compared to the corresponding FALs to determine the appropriate resolution to Decision I and Decision II. For Decision I, a UCL of the average concentration for a contaminant exceeding a FAL would cause a determination that a COC is present within the CAS.

The Decision II population parameter is an individual analytical result from a bounding sample. For Decision II, a single bounding sample result for a contaminant exceeding a FAL would cause a determination that the contamination is not bounded.

\section{B.6.2 Action Levels}

The PALs presented in this section are to be used for site screening purposes. They are not intended to be used as cleanup action levels or FALs. However, they are useful in screening out contaminants not present in sufficient concentrations to warrant further evaluation and, therefore, streamline the consideration of remedial alternatives. The RBCA process used to establish FALs is described in the 
Industrial Sites Project Establishment of Final Action Levels (NNSA/NSO, 2006). This process conforms with NAC 445A.227 (NAC, 2006a) which lists the requirements for sites with soil contamination. For the evaluation of corrective actions, NAC 445A.22705 (NAC, 2006b) requires the use of ASTM Method E 1739-95 (ASTM, 1995) to "conduct an evaluation of the site, based on the risk it poses to public health and the environment, to determine the necessary remediation standards (i.e., FALs) or to establish that corrective action is not necessary."

This RBCA process defines three tiers (or levels) of evaluation involving increasingly sophisticated analyses:

- Tier 1 evaluation - Sample results from source areas (highest concentrations) are compared to action levels based on generic (non-site-specific) conditions (i.e., the PALs established in the SAFER Plan). The FALs may then be established as the Tier 1 action levels, or the FALs may be calculated using a Tier 2 evaluation.

- Tier 2 evaluation - Conducted by calculating Tier 2 SSTLs using site-specific information as inputs to the same or similar methodology used to calculate Tier 1 action levels. The Tier 2 SSTLs are then compared to individual sample results from reasonable points of exposure (as opposed to the source areas as is done in Tier 1) on a point-by-point basis. Total TPH concentrations will not be used for risk-based decisions under Tier 2 or Tier 3. Rather, the individual chemicals of concern will be compared to the SSTLs.

- Tier 3 evaluation - Conducted by calculating Tier 3 SSTLs on the basis of more sophisticated risk analyses using methodologies described in Method E1739-95 that consider site-, pathway-, and receptor-specific parameters.

The comparison of laboratory results to FALs and the evaluation of potential corrective actions will be included in the investigation report. The FALs will be defined (along with the basis for definition) in the investigation report.

\section{B.6.2.1 Chemical PALs}

Except as noted herein, the chemical PALs are defined as the EPA Region 9 Risk-Based PRGs for chemical contaminants in industrial soils (EPA, 2004). Background concentrations for RCRA metals and zinc will be used instead of PRGs when natural background concentrations exceed the PRG, as is often the case with arsenic on the NTS. Background is considered the average concentration, plus two standard deviations of the average concentration, for sediment samples collected by the Nevada Bureau of Mines and Geology throughout the Nevada Test and Training Range (formerly the Nellis 
Air Force Range) (NBMG, 1998). For detected chemical COPCs without established PRGs, the protocol used by the EPA Region 9 in establishing PRGs (or similar) will be used to establish PALs. If used, this process will be documented in the investigation report.

\section{B.6.2.2 Total Petroleum Hydrocarbons PALs}

The PAL for TPH is 100 ppm as listed in NAC 445A.2272 (NAC, 2006c).

\section{B.6.2.3 Radionuclide PALs}

The PALs for radiological contaminants (other than tritium) are based on the NCRP Report No. 129 recommended screening limits for construction, commercial, industrial land-use scenarios (NCRP, 1999) scaled to 25 mrem/yr dose constraint (Murphy, 2004) and the generic guidelines for residual concentration of radionuclides in DOE Order 5400.5 (DOE, 1993). These PALs are based on the construction, commercial, and industrial land-use scenario provided in the guidance, and are appropriate for the NTS, based on future land use scenarios as presented in Section B.2.2. The PAL for tritium is based on the UGTA Project limit of 400,000 pCi/L for discharge of water containing tritium (NNSA/NV, 2002b).

Materials/structures that have the potential for surface contamination may be surveyed for unrestricted release as given in the NV/YMP Radiological Control Manual (NNSA/NSO, 2004).

\section{B.6.3 Decision Rules}

The decision rules applicable to both Decision I and Decision II are:

- If COC contamination is inconsistent with the CSM or extends beyond the spatial boundaries identified in Section B.5.2, then work will be suspended and the investigation strategy reconsidered, else the decision will be to continue sampling to define the extent.

The decision rules for Decision I are:

- If the population parameter of any COPC in the Decision I population of interest (defined in Step 4) exceeds the corresponding FAL, then that contaminant is identified as a COC, the contaminated material removed, or Decision II samples collected until an estimate of the extent of contaminated material has been made. 
- If no COC associated with a release from the CAS is detected, then further assessment of the CAS is not required and the corrective action alternative of no further action will be selected. If a COC associated with a release from the CAS is detected, then additional sampling will be conducted to determine the extent of COC contamination. If the extent of the contamination is defined and additional remediation is feasible, then clean close the site by removing the contaminated media until all contamination has been removed. If the extent of contamination has been determined and additional remediation is not feasible, then the contaminated area will be close in place with appropriate use restrictions and the extent of contamination defined.

- If a waste is present that, if released, has the potential to cause the future contamination of site environmental media, then a corrective action will be determined, else no further action will be necessary.

The decision rules for Decision II are:

- If the population parameter (the observed concentration of any COC) in the Decision II population of interest (defined in Step 4) exceeds the corresponding FAL, then additional samples will be collected to complete the Decision II evaluation. If sufficient information is available to define the extent of COC contamination and confirm that closure objectives were met, then further assessment of the CAS is not required. If sufficient information is not available to define the extent of contamination or confirm that closure objectives were met, then additional samples will be collected until the extent is defined.

- If valid analytical results are available for the waste characterization samples defined in Section B.8.0, then the decision will be that sufficient information exists to characterize the IDW for disposal, and determine potential remediation waste types, else collect additional waste characterization samples. 


\section{B.7.0 Step 6 - Specify Performance or Acceptance Criteria}

Step 6 of the DQO process defines the decision hypotheses, specifies controls against false rejection and false acceptance decision errors, examines consequences of making incorrect decisions from the test, and places acceptable limits on the likelihood of making decision errors.

\section{B.7.1 Decision Hypotheses}

The baseline condition (i.e., null hypothesis) and alternative condition for Decision I are:

- Baseline condition - A COC is present.

- Alternative condition - A COC is not present.

The baseline condition (i.e., null hypothesis) and alternative condition for Decision II are as follows:

- Baseline condition - The extent of a COC has not been defined.

- Alternative condition - The extent of a COC has been defined.

Decisions and/or criteria have false negative or false positive errors associated with their determination. The impact of these decision errors and the methods that will be used to control these errors are discussed in the following subsections. In general terms, confidence in DQO decisions based on judgmental sampling results will be established qualitatively by:

- The development of and concurrence of CSMs (based on process knowledge) by stakeholder participants during the DQO process.

- Testing the validity of CSMs based on investigation results.

- Evaluating the quality of the data based on DQI parameters.

\section{B.7.2 False Negative Decision Error}

The false negative decision error would indicate deciding that a COC is not present when it is (Decision I), or deciding that the extent of a COC has been defined when it has not (Decision II), or deciding that closure objectives were met when they were not (Decision II). In all cases, the potential consequence is an increased risk to human health and environment. 
In judgmental sampling, the selection of the number and location of samples is based on knowledge of the feature or condition under investigation and on professional judgment (EPA, 2002). Judgmental sampling conclusions regarding the target population depend upon the validity and accuracy of professional judgment.

The false negative decision error (where consequences are more severe) for judgmental sampling designs is controlled by meeting these criteria:

- For Decision I, having a high degree of confidence that the sample locations selected will identify COCs, if present within the CAS. For Decision II, having a high degree of confidence that the sample locations selected will identify the extent of COCs.

- Having a high degree of confidence that analyses conducted will be sufficient to detect COCs present in the samples.

- Having a high degree of confidence that the dataset is of sufficient quality and completeness.

To satisfy the first criterion, Decision I samples must be collected in areas most likely to be contaminated by COCs (supplemented by random samples where appropriate). Decision II samples must be collected in areas that represent the lateral and vertical extent of contamination (above FALs). The following characteristics must be considered to control decision errors for the first criterion:

- Source and location of release

- Chemical nature and fate properties

- Physical transport pathways and properties

- Hydrologic drivers

These characteristics were considered during the development of the CSMs and selection of sampling locations. The field-screening methods and biasing factors listed in Section B.4.2.1 will be used to further ensure that appropriate sampling locations are selected to meet these criteria. Radiological survey instruments and field-screening equipment will be calibrated and checked in accordance with the manufacturer's instructions and approved procedures. The investigation report will present an assessment on the DQI of representativeness that samples were collected from those locations that best represent the populations of interest as defined in Section B.5.1. 
To satisfy the second criterion, Decision I samples will be analyzed for the chemical and radiological parameters listed in Section 3.2 of this SAFER Plan. Decision II samples will be analyzed for those chemical and radiological parameters that identified unbounded COCs. The DQI of sensitivity will be assessed for all analytical results to ensure that all sample analyses had measurement sensitivities (detection limits) that were less than or equal to the corresponding FALs. If this criterion is not achieved, the affected data will be assessed (for usability and potential impacts on meeting site characterization objectives) in the investigation report.

To satisfy the third criterion, the entire dataset, as well as individual sample results, will be assessed against the DQIs of precision, accuracy, comparability, and completeness as defined in the Industrial Sites QAPP (NNSA/NV, 2002a) and in Section 6.2.2 of this SAFER Plan. The DQIs of precision and accuracy will be used to assess overall analytical method performance as well as to assess the need to potentially “flag” (qualify) individual contaminant results when corresponding QC sample results are not within the established control limits for precision and accuracy. Data qualified as estimated for reasons of precision or accuracy may be considered to meet the constituent performance criteria based on an assessment of the data. The DQI for completeness will be assessed to ensure that all data needs identified in the DQO have been met. The DQI of comparability will be assessed to ensure that all analytical methods used are equivalent to standard EPA methods so that results will be comparable to regulatory action levels that have been established using those procedures. Strict adherence to established procedures and QA/QC protocol protects against false negatives. Site-specific DQIs are discussed in more detail in Section 6.2.2 of this SAFER Plan.

To provide information for the assessment of the DQIs of precision and accuracy, the following QC samples will be collected as required by the Industrial Sites QAPP (NNSA/NV, 2002a):

- Field duplicates (minimum of 1 per matrix per 20 environmental samples)

- Laboratory QC samples (minimum of 1 per matrix per 20 environmental samples, or 1 per CAS per matrix, if less than 20 collected)

\section{B.7.3 False Positive Decision Error}

The false positive decision error indicates that a COC is present when it is not, or a COC is unbounded when it is not, resulting in unnecessary sampling and analysis, thus increased costs. 
False positive results are typically attributed to laboratory and/or sampling/handling errors that could cause cross contamination. To protect against cross contamination, decontamination of sampling equipment will be conducted according to established and approved procedures, and only clean sample containers will be used. To determine whether a false positive analytical result may have occurred, the following quality control samples will be collected as required by the Industrial Sites QAPP (NNSA/NV, 2002a):

- Trip blanks (1 per sample cooler containing VOC environmental samples)

- Equipment blanks (1 per sampling event for each type of decontamination procedure)

- Source blanks (1 per source lot per sampling event)

- Field blanks (minimum of 1 per CAS, additional if field conditions change) 


\section{B.8.0 Step 7 - Develop the Plan for Obtaining Data}

Step 7 of the DQO process selects and documents a design that will yield data that will best achieve performance or acceptance criteria. Judgmental sampling schemes will be implemented to select sample locations and evaluate analytical results for CAU 124. Judgmental sampling allows the methodical selection of sample locations that target the populations of interest (defined in Step 4).

\section{B.8.1 Decision I Sampling}

A judgmental sampling design will be implemented for CAU 124 CASs. Because individual sample results, rather than an average concentration, will be used to compare to FALs at the CASs undergoing judgmental sampling, statistical methods to generate site characteristics will not be used. Adequate representativeness of the entire target population may not be a requirement to developing a sampling design. If good prior information is available on the target site of interest, then the sampling may be designed to collect samples only from areas known to have the highest concentration levels on the target site. If the observed concentrations from these samples are below the action level, then a decision can be made that the site does not contain unsafe levels of the contaminant without the samples being truly representative of the entire area (EPA, 2006).

Sample locations will be selected to satisfy the DQI of representativeness in that samples collected from selected locations will best represent the populations of interest as defined in Section B.5.1. To meet this criterion for judgmentally sampled sites, a biased sampling strategy will be used for Decision I samples to target areas with the highest potential for contamination, if it is present in the CAS. Sample locations will be determined based on process knowledge, previously acquired data, or the field-screening and biasing factors listed in Section B.4.2.1. If biasing factors are present in soils below locations where Decision I samples were removed, additional Decision I soil samples will be collected at depth intervals selected by the SS based on biasing factors to a depth where the biasing factors are no longer present. The SS has the discretion to modify the judgmental sample locations, but only if the modified locations meet the decision needs and criteria stipulated in this DQO. 


\section{B.8.2 Decision II Sampling}

To meet the DQI of representativeness for Decision II samples (that Decision II sample locations represent the population of interest as defined in Section B.5.1), judgmental sampling locations at each CAS will be selected based on the outer boundary sample locations where COCs were detected, the CSM, and other field-screening and biasing factors listed in Section B.4.2. In general, sample locations will be arranged in a triangular pattern around the Decision I location or area at distances based on site conditions, process knowledge, and biasing factors. If COCs extend beyond the initial step-outs, Decision II samples will be collected from incremental step-outs. Initial step-outs will be at least as deep as the vertical extent of contamination defined at the Decision I location and the depth of the incremental step-outs will be based on the deepest contamination observed at all locations. A clean sample (i.e., concentrations less than FALs) collected from each step-out direction (lateral or vertical) will define extent of contamination in that direction. The number, location, and spacing of step-outs may be modified by the SS, as warranted by site conditions.

The following sections discuss CAS-specific investigation activities, including proposed sample locations. As the sampling strategy for each CAS is developed, specific biasing factors will be described. In the absence of biasing factors, samples will be collected from the default sampling locations described for each CAS.

\section{B.8.3 Corrective Action Site 08-02-01, Underground Storage Tank}

The judgmental sample locations at CAS 08-02-01 have been selected based on the 4-in. PVC pipe extending from the ground, and the disturbed and sightly subsided soils directly around the pipe.

Figure B.8-1 shows the site conditions for CAS 08-02-01. A Decision I sample will be collected at the surface contact beside the exposed pipe. Additional Decision I samples will be collected based on biasing factors during excavation of the UST described in Section B.4.2.1. The area of the UST will be excavated. If a UST is present, the contents, if any, of each phase inside the UST will be sampled; two soil samples will be collected at the base of the UST; one soil sample will be collected from the inlet, and one soil sample will be collected from the outlet as depicted in Figure B.8-2. The UST will be closed in accordance with NAC Section 459.9972, “UST Closure” and the contents, if any, will be 


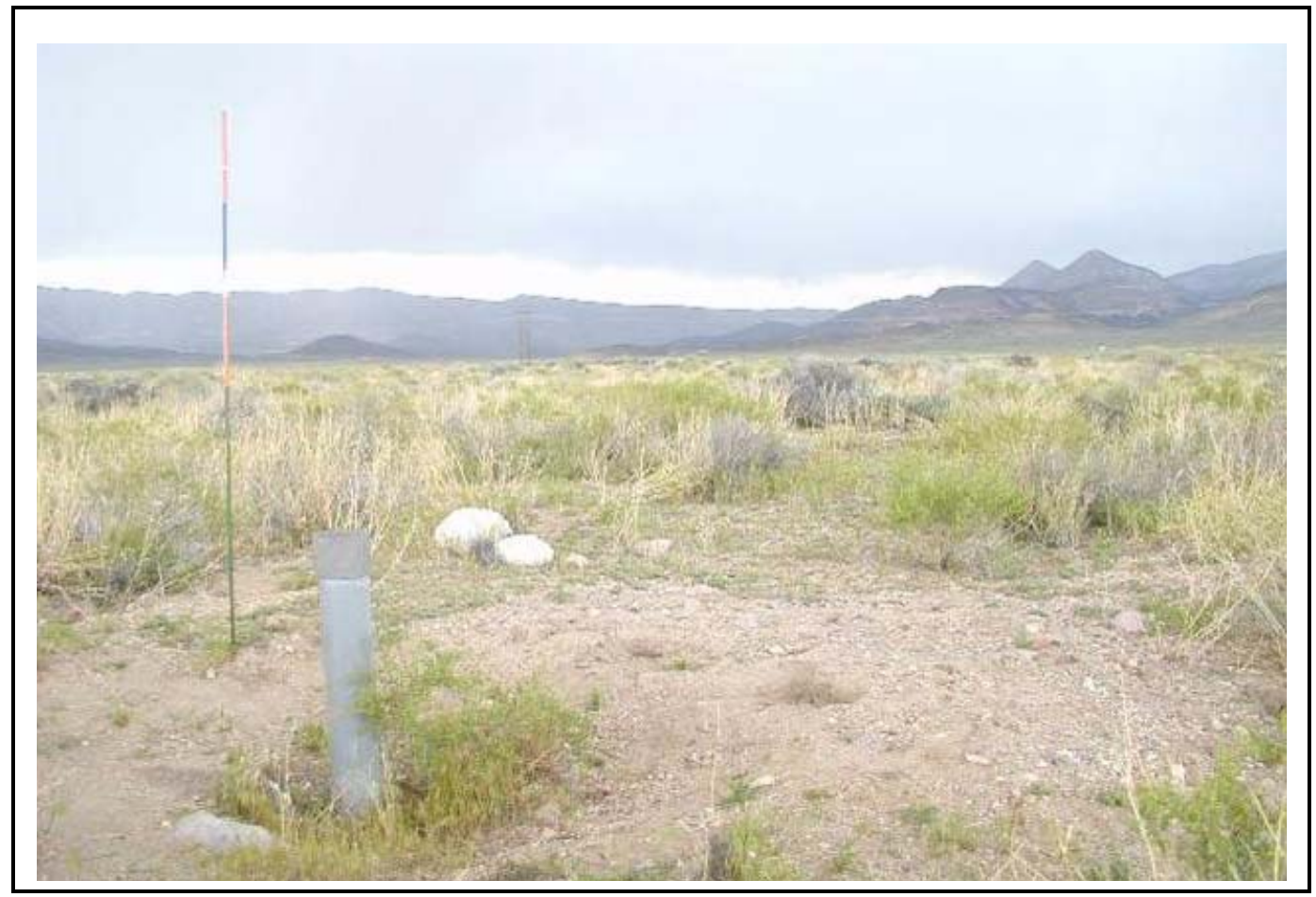

Figure B.8-1

\section{Current Site Conditions at CAS 08-02-01}

removed (NAC, 2005). The USTs and contents, if any, will be disposed of in accordance with Section 6.0 of this SAFER Plan.

If no UST is present, the excavated material will be observed for biasing factors, such as staining to the undisturbed native soil interface. If no biasing factors are observed, one soil sample will be collected at the undisturbed native soil interface. If the undisturbed soil interface cannot be determined, one soil sample will be collected at approximately $12 \mathrm{ft}$, and one soil sample will be collected at approximately $15 \mathrm{ft}$. Samples will be submitted for analysis in accordance with the analytical program listed in Table 3-1. 


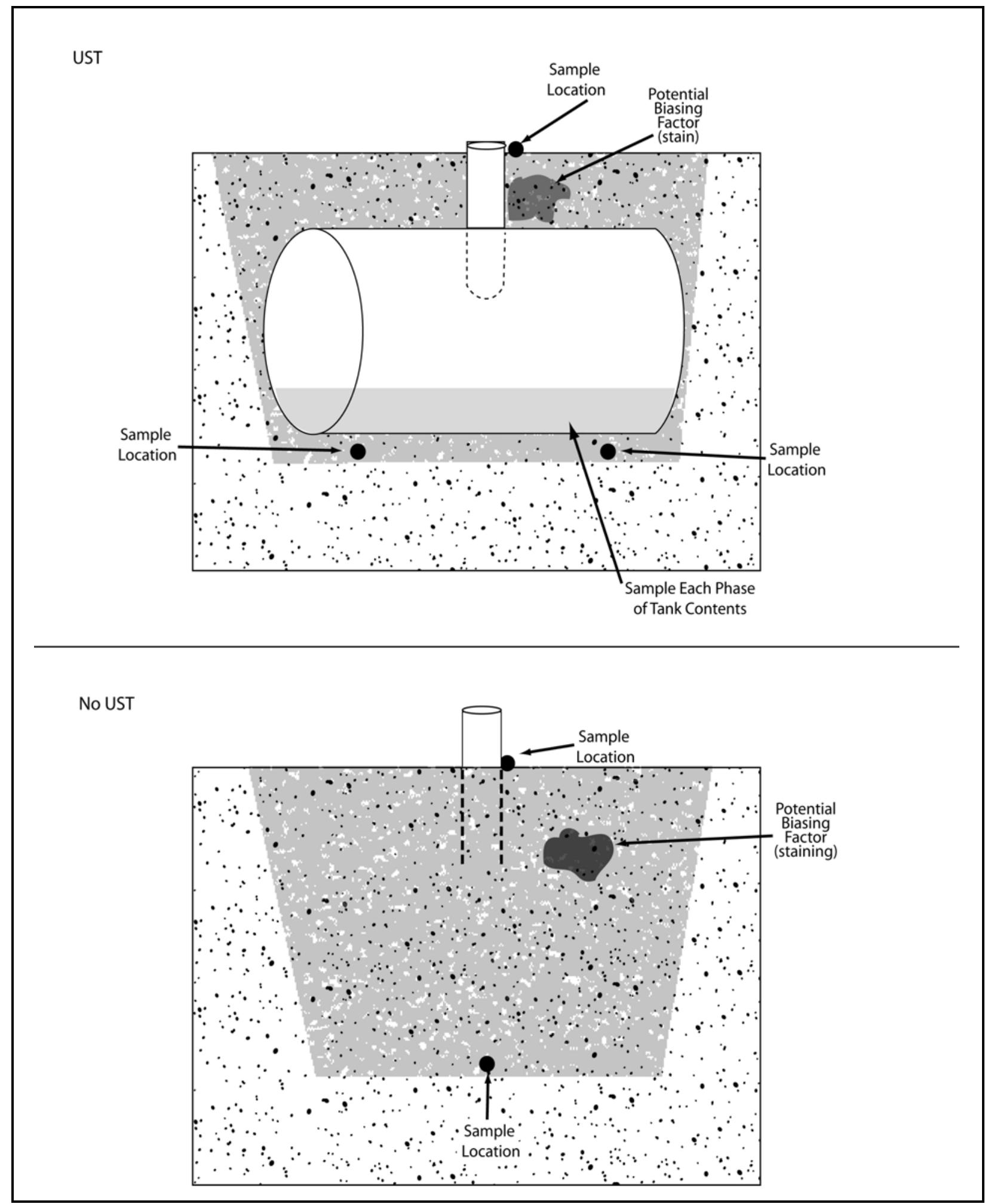

Figure B.8-2

Proposed Sample Locations at CAS 08-02-01 


\section{B.8.4 Corrective Action Site 15-02-01, Irrigation Piping}

This section discusses the sampling and analysis design for CAS 15-02-01 located at Area 15 EPA Farm. The EPA Farm sample strategy is developed based on process knowledge, a 2006 geophysical survey, and a 2006 demarcation survey.

Figure B.8-3 shows the current site conditions for CAS 15-02-01. Figure B.8-4 shows the planned Decision I sample locations.

Two locations along the irrigation lines are selected in each Farm Plot. These locations will be the proximinal and distal ends of the irrigation lines. One swipe at each location; one surface and one subsurface (approximately 6 in.) soil sample will be collected. Four judgmental samples will be collected at randomized grid locations in each plot as determined using VSP software as shown on Figure B.8-4.

Within the boundary of CAS 15-02-01, there are two concrete pads. One was a greenhouse and one was a storage shed. Surface soil samples will be collected at the middle edge of each side of each concrete pad. Also, samples will be collected from the concrete pads based on biasing factors discussed in Section B.4.2.1 to determine if contamination on the pad could result in future release of COCs.

To confirm the demarcation survey, six judgmental surface soil samples will be collected outside the CAS 15-02-01 boundary. The results of this sampling will be used to determine the background radiological concentration that would not be associated with the potential application of radionuclides on the EPA Farm Plots. Due to the nature of the fallout from the atmospheric testing at NTS and the location of the EPA Farm, the following is a potential sampling strategy. One surface soil sample will be collected at an approximate distance of 25 to $30 \mathrm{ft}$ southeast of the southwest corner. Two surface soil samples will be collected at an approximate distance of 25 to $30 \mathrm{ft}$ from the west fence line along the western edge of Plot A. One surface soil sample at an approximate distance of 25 to $30 \mathrm{ft}$ from the west fence line along the middle western edge of Plot B. Two surface soil samples will be collected 25 to $30 \mathrm{ft}$ from the northern fence line of both Plot A and B and spaced approximately 100 ft apart. 


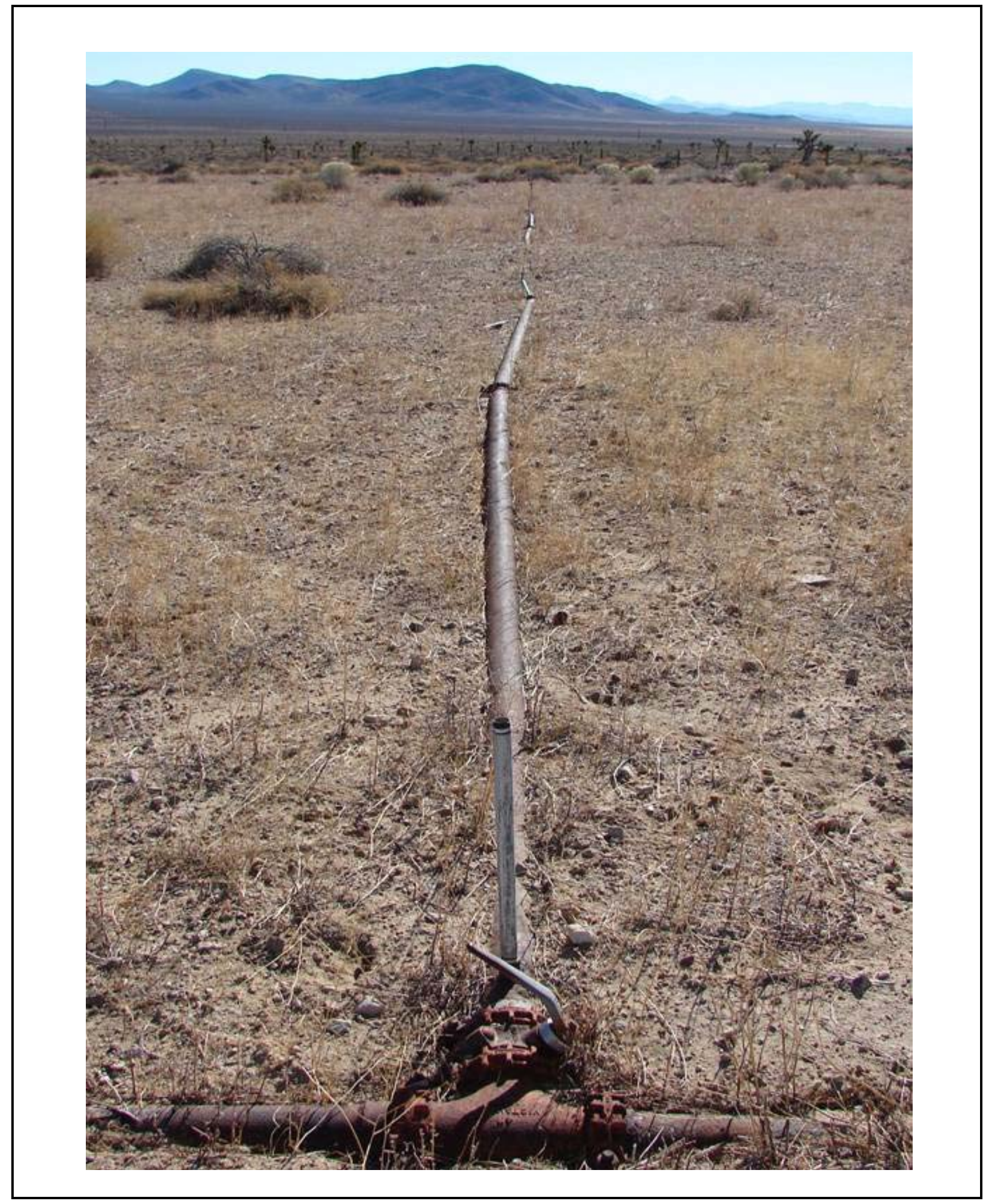

Figure B.8-3

Current Site Conditions at CAS 15-02-01 


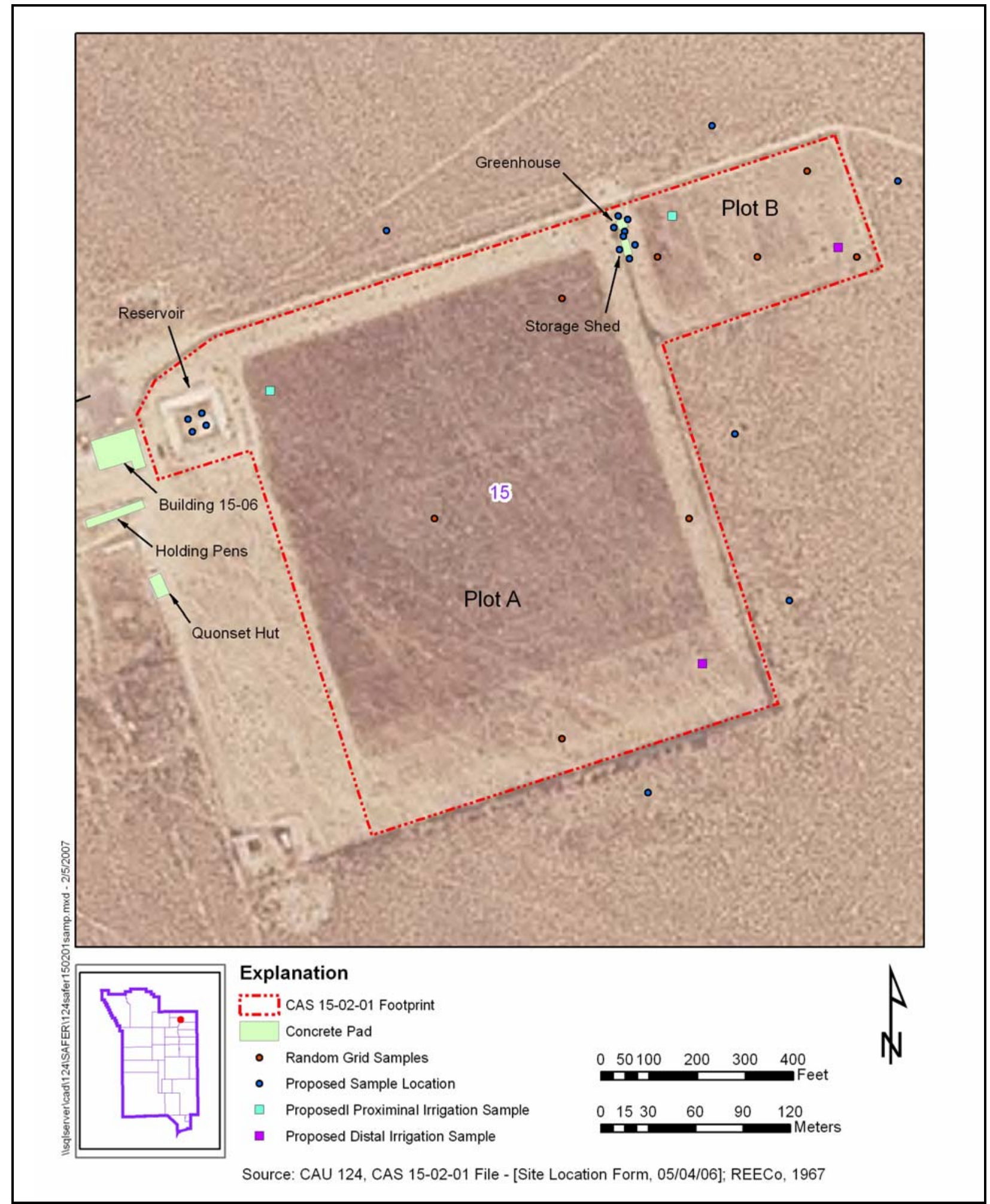

Figure B.8-4

Proposed Sample Locations at CAS 15-02-01 
The sampling strategy of the reservior will include four judgmental surface soil samples. The results of this sampling will be used to determine the background radiological concentration that would not be associated with the potential mixing of radionuclides within the reservoir. If the concentrations are similar between the background and reservoir samples, contamination will be attributed to atmospheric sources and not the mixing of radionuclides for application to the fields. The potential sample strategy includes four judgmental surface samples are collected from the bottom of the reservior. Samples will be submitted for analysis in accordance with the analytical program listed in Table 3-1.

\section{B.8.5 Corrective Action Site 16-02-03, Underground Storage Tank}

The judgmental sample locations at CAS 16-02-03 have been selected based on two exposed 1-in. metal pipes extended from the surface, and the 2003 Science Applications International Corporation geophysical survey that located a UST and associated piping.

Figure B.8-5 shows the current site conditions for CAS 16-02-03. Figure B.8-6 shows the planned Decision I sample locations.

A Decision I sample will be collected at the surface contact next to the exposed pipe. Additional Decision I samples will be collected based on biasing factors during excavation of the UST described in Section B.4.2.1.

The area of the UST will be excavated. If a UST is present, the contents, if any, of each phase inside the UST will be sampled; two soil samples will be collected at the base of the UST; one soil sample will be collected from the inlet, and one soil sample will be collected from the outlet as depicted at the top of Figure B.8-6. The UST will be closed in accordance with NAC Section 459.9972, “UST Closure” and the contents, if any, will be removed (NAC, 2005). The USTs and contents, if any, will be disposed of in accordance with Section 6.0 of this SAFER Plan.

If no UST is present, the excavated material will be observed for any biasing factors, such as to the undisturbed native soil interface. If no biasing factors are observed, one soil sample will be collected at the undisturbed native soil interface as depicted at the bottom of Figure B.8-6. If the undisturbed soil interface cannot be determined, one soil sample will be collected at approximately $12 \mathrm{ft}$, and one 


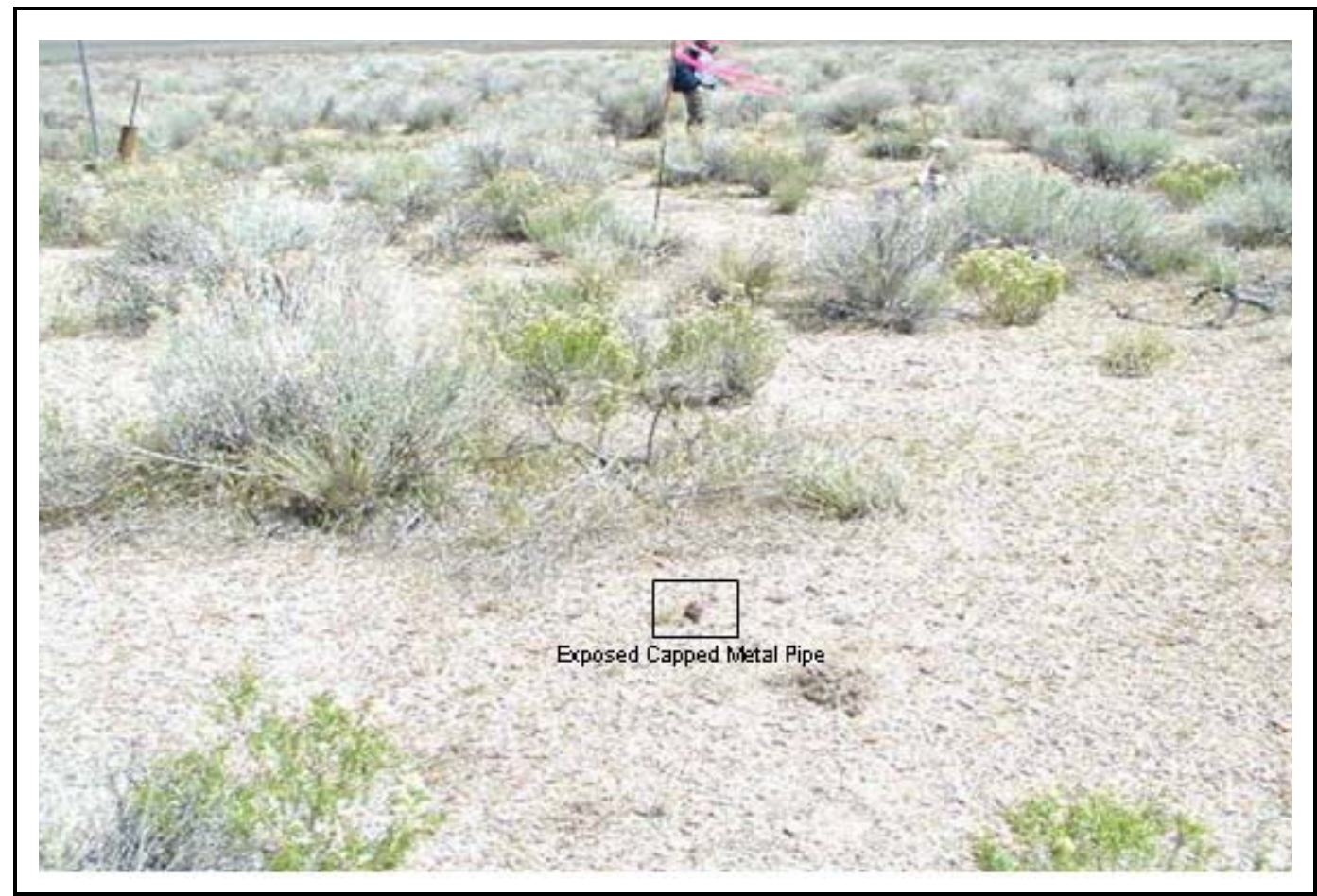

Figure B.8-5

Current Site Conditions at CAS 16-02-03

soil sample will be collected at approximately $15 \mathrm{ft}$. Samples will be submitted for analysis in accordance with the analytical program listed in Table 3-1. 
UST

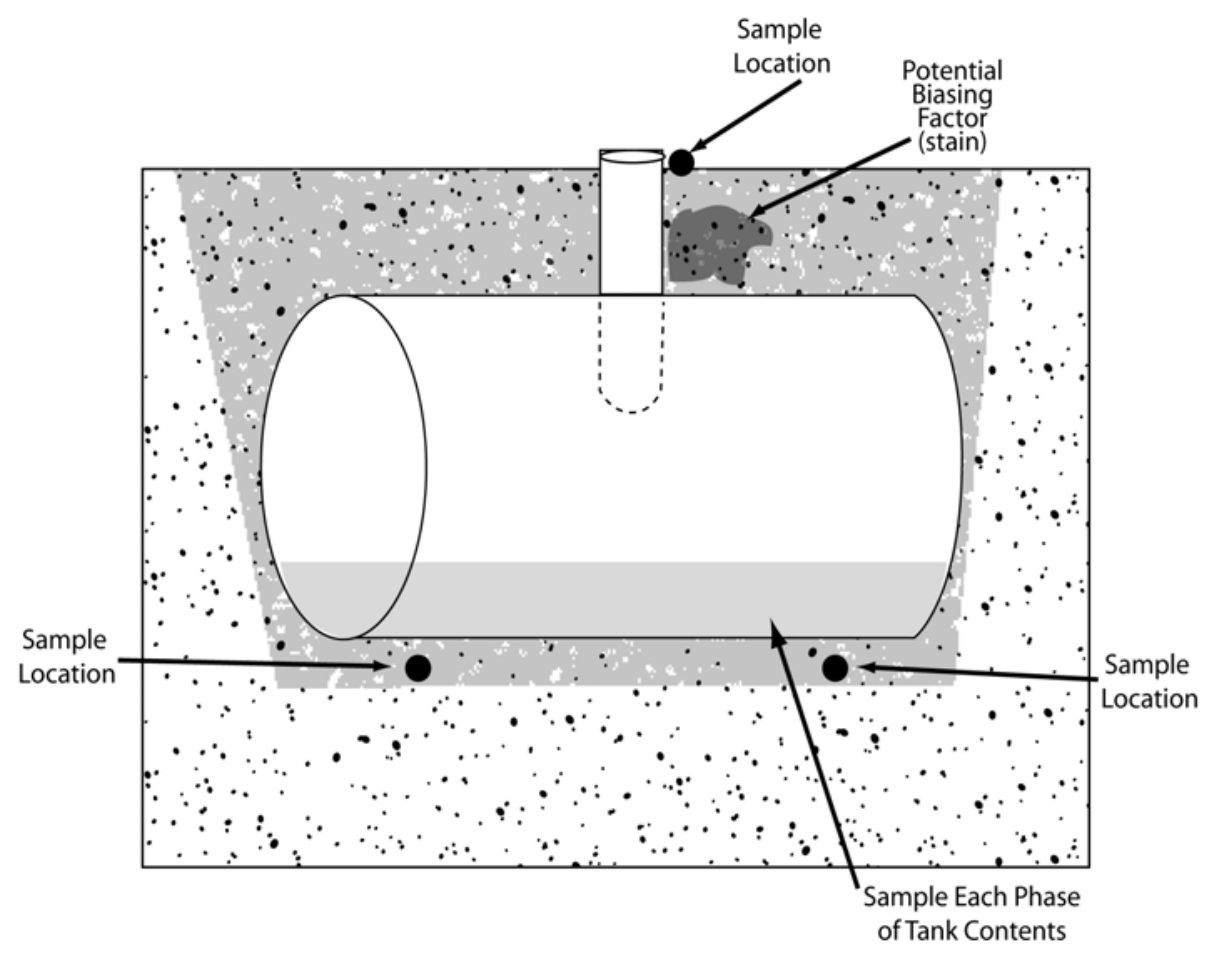

No UST

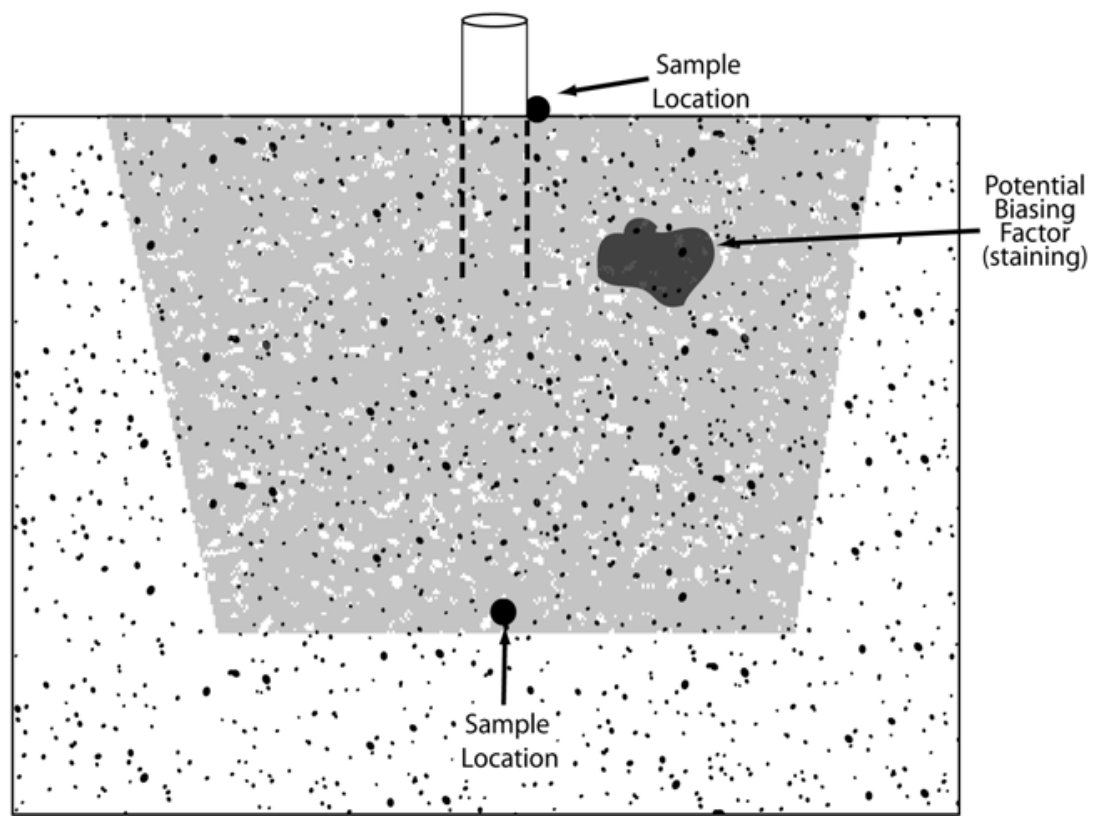

Figure B.8-6

Proposed Sample Locations at CAS 16-02-03 


\section{B.8.6 Corrective Action Site 16-02-04, Fuel Oil Piping}

The sample locations at CAS 16-02-04 have been selected based on the fuel oil piping that was connected to a former 2,000-gal fuel oil AST and a recent informal utility survey concluded the fuel oil piping was still in place. Current site conditions are depicted in Figure B.8-7.

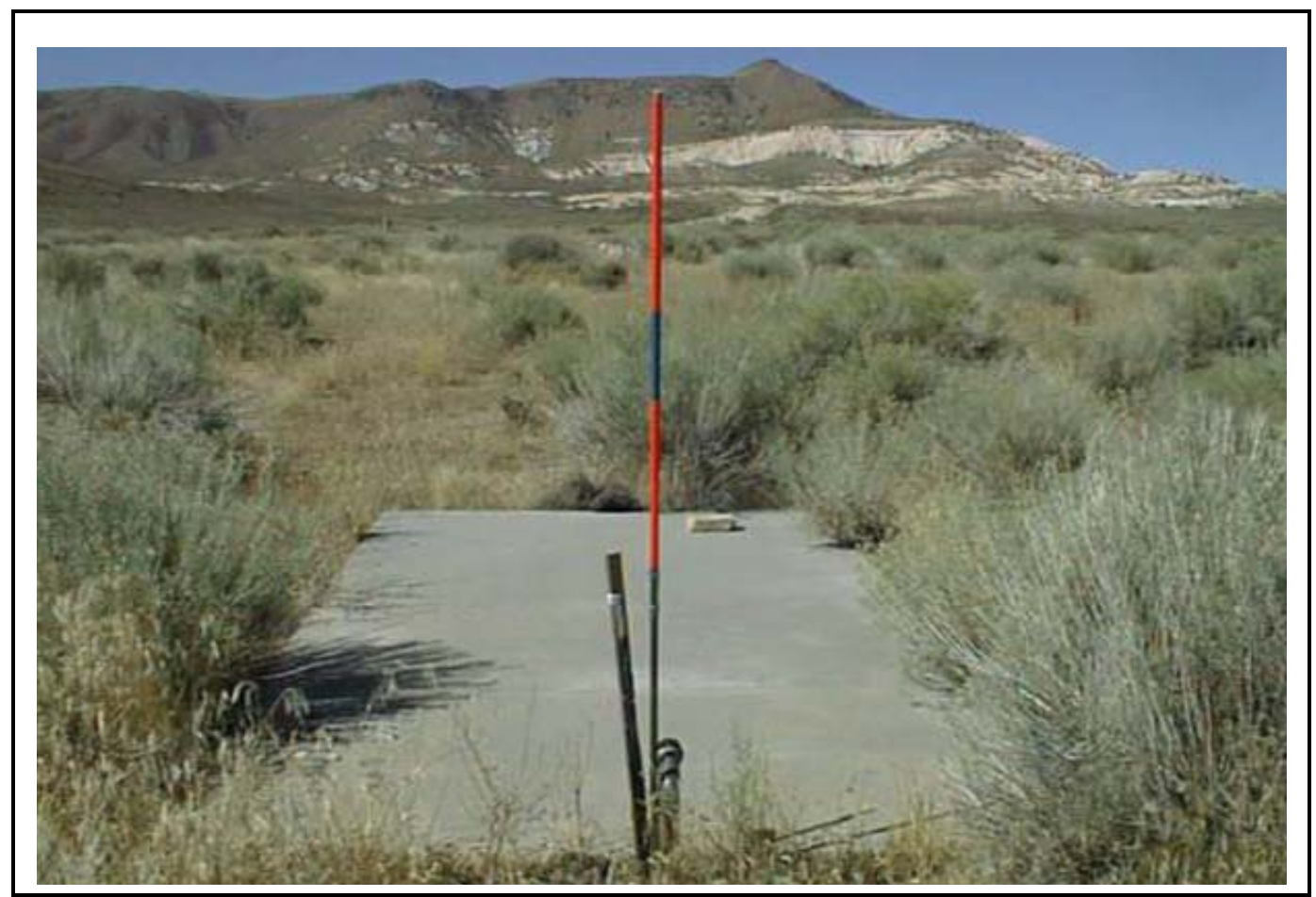

Figure B.8-7

Current Site Conditions at CAS 16-02-04

Decision I samples will be collected as depicted in Figure B.8-8 at all end-points along the fuel oil pipe line where connections would have been made. During excavation of the fuel oil piping ends additional samples may be collected if biasing factors are observed, such as staining as described in Section B.4.2.1.

Decision I surface soil samples will be collected at the middle edge of each side of the concrete pad. Samples will be submitted for analysis in accordance with the analytical program listed in Table 3-1. 


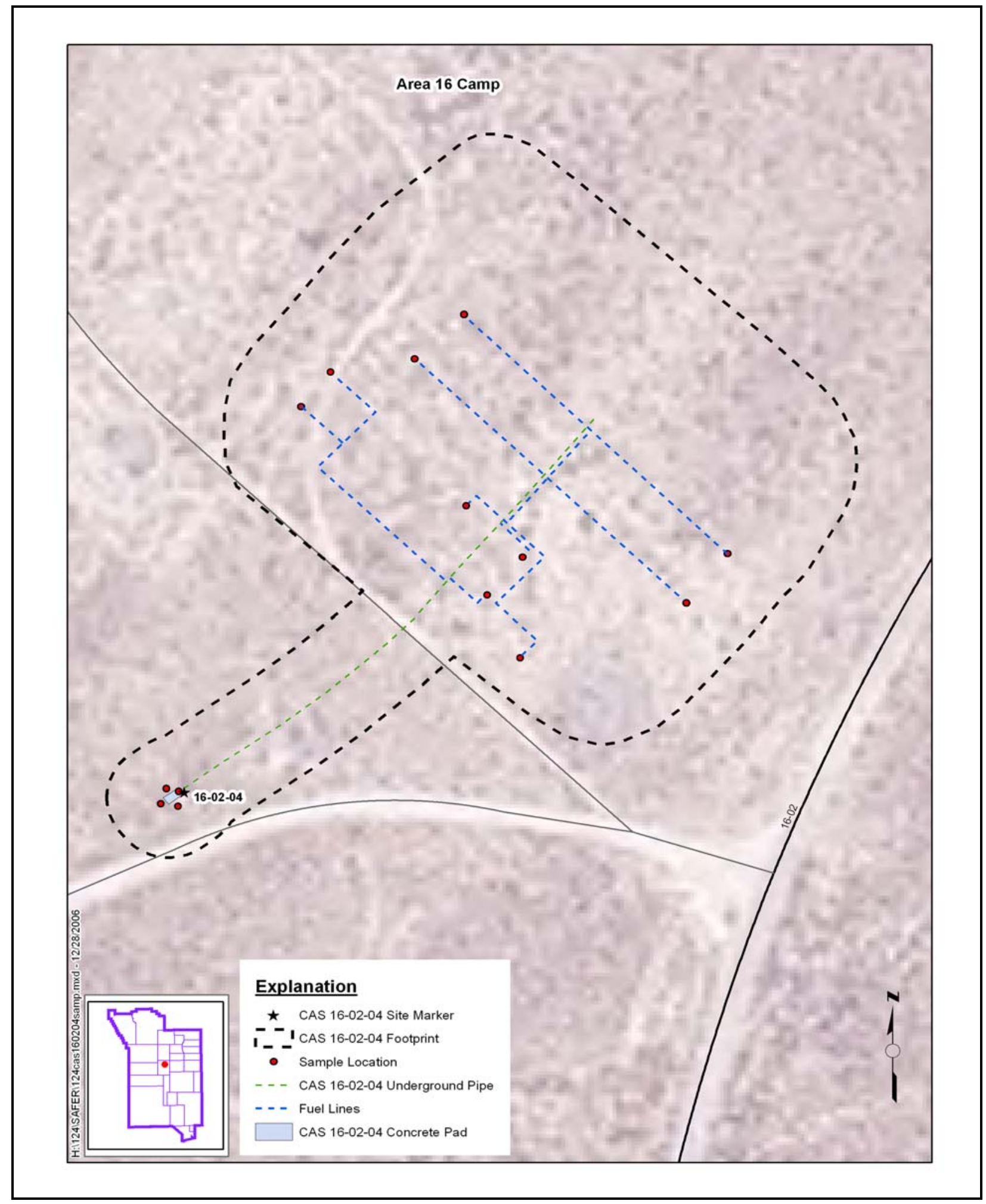

Figure B.8-8

Proposed Sample Locations for CAS 16-02-04 


\section{B.8.7 Corrective Action Site 16-99-04, Fuel Line (Buried) and UST}

The judgmental sample locations at CAS 16-99-04 have been selected based on the 2003 geophysical survey that located a UST and associated piping.

Figure B.8-9 shows the current site conditions for CAS 16-99-04. Figure B.8-10 shows the planned Decision I sample locations.

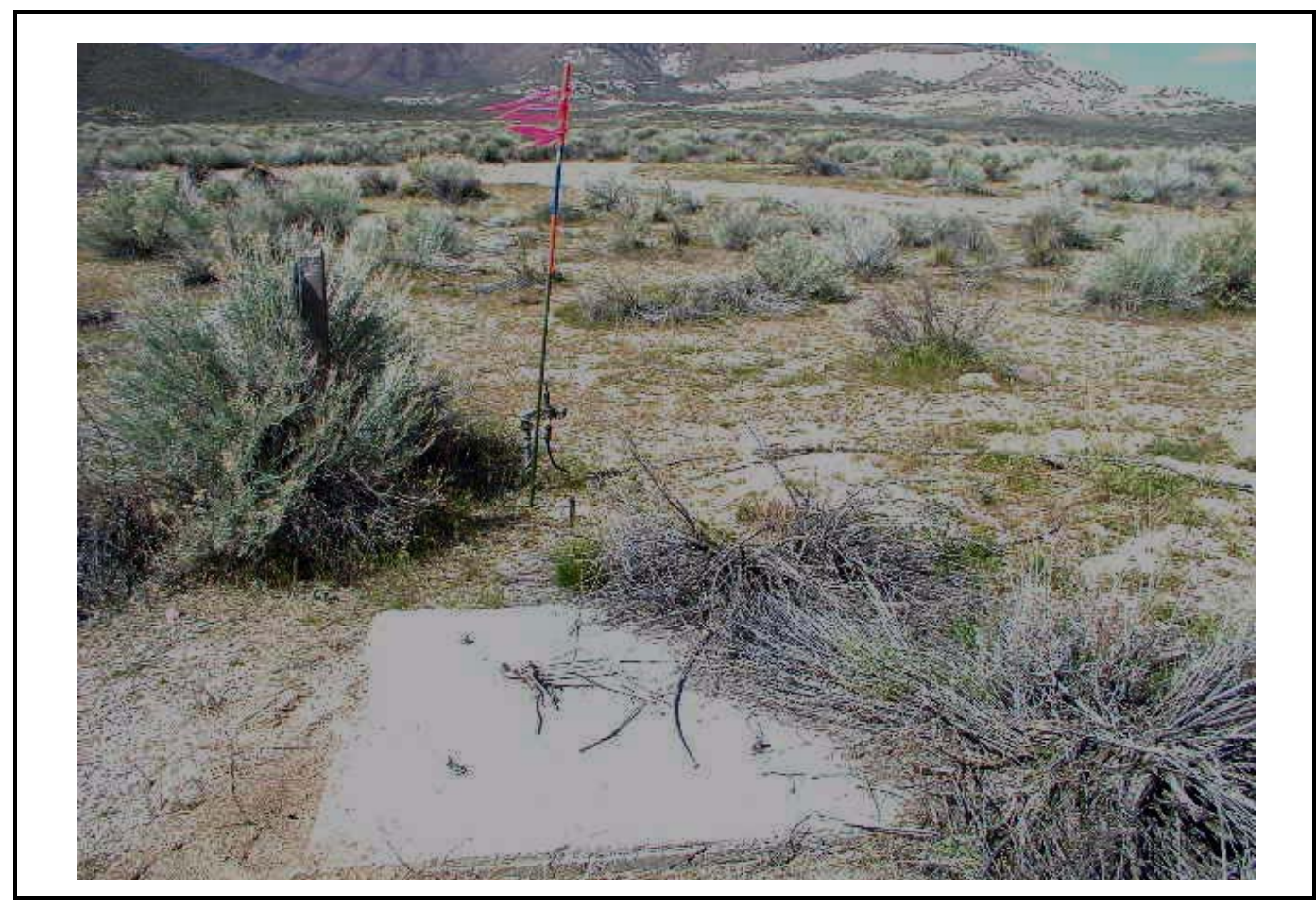

Figure B.8-9

Current Site Conditions at CAS 16-99-04

Decision I surface soil samples will be collected at the middle edge of each side of the concrete pad. Also, one surface soil sample will be collected at the base of exposed piping associated with CAS 16-99-04.

A Decision I sample will be collected at the surface contact beside the exposed pipe. Additional Decision I samples will be collected based on biasing factors during excavation of the UST described in Section B.4.2.1. 
UST

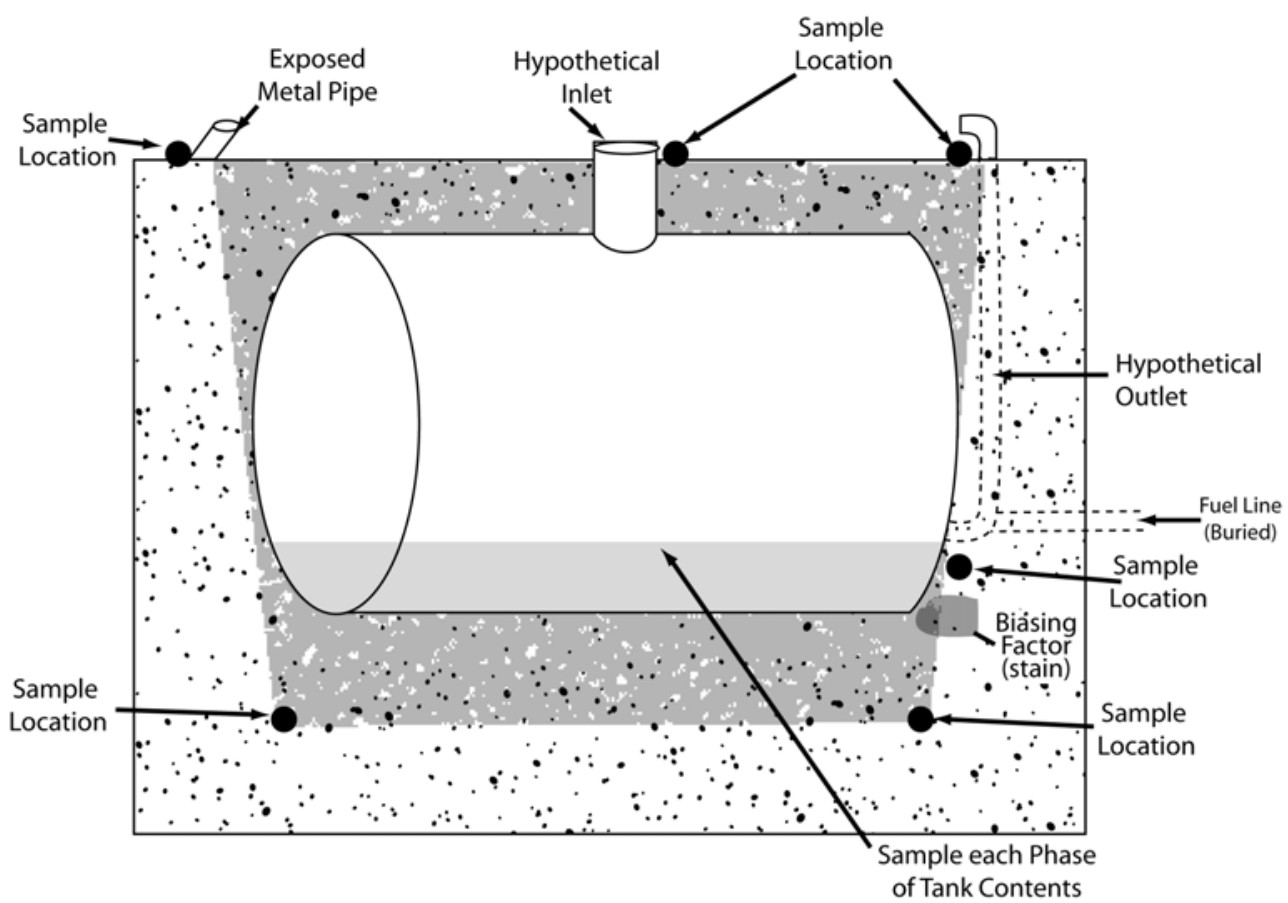

NO UST

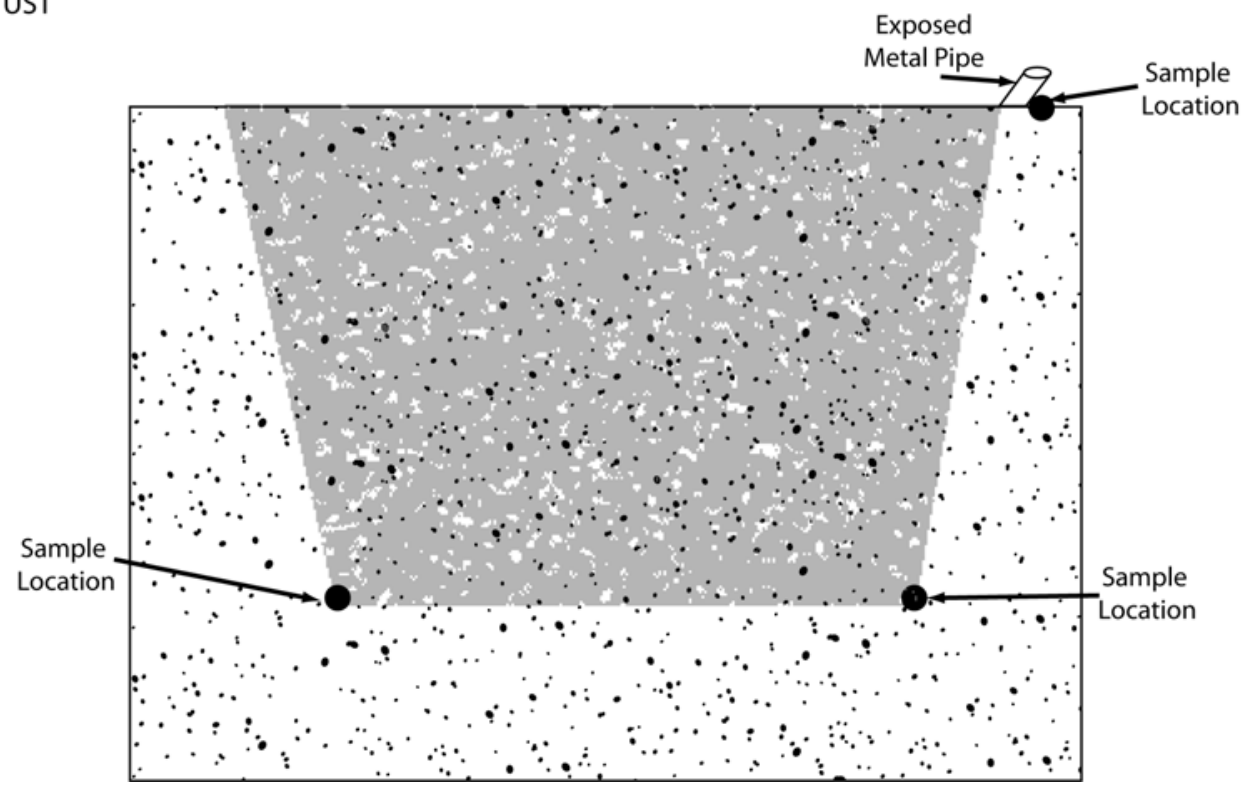

Figure B.8-10

Proposed Sample Locations at CAS 16-99-04 
The area of the UST will be excavated. If a UST is present, the contents, if any, of each phase inside the UST will be sampled; two soil samples will be collected at the base of the UST; one soil sample will be collected from the inlet, and one soil sample will be collected from the outlet as depicted at the top of Figure B.8-10. The UST will be closed in accordance with NAC Section 459.9972, "UST Closure” and the contents, if any, will be removed (NAC, 2005). The USTs and contents, if any, will be disposed of in accordance with Section 6.0 of this SAFER Plan.

If no UST is present, the excavated material will be observed for biasing factors, such as staining to the undisturbed native soil interface. If no biasing factors are observed, one soil sample will be collected at the undisturbed native soil interface as depicted at the bottom of Figure B.8-10. If the undisturbed native soil interface cannot be determined, one soil sample will be collected at approximately $12 \mathrm{ft}$, and one soil sample will be collected at approximately $15 \mathrm{ft}$.

Decision I samples will be collected at all end-points along the fuel line where connections would have been made. During excavation of the fuel line additional soil samples may be collected if biasing factors are observed, such as staining, as described in Section B.4.2.1. Samples will be submitted for analysis in accordance with the analytical program listed in Table 3-1. 


\section{B.9.0 References}

ARL/SORD, see Air Resources Laboratory/Special Operations and Research Division.

Air Resources Laboratory/Special Operations and Research Division. 2006. Air Resources Laboratory/Special Operations and Research Division Web Site. As accessed at http://www.sord.nv.doe.gov/home_climate.htm on 16 May.

ASTM, see American Society for Testing and Materials.

American Society for Testing and Materials. 1995. Standard Guide for Risk-Based Corrective Action Applied at Petroleum Release Sites, ASTM E 1739-95 (Reapproved 2002). Philadelphia, PA.

DOE, see U.S. Department of Energy.

DOE/NV, see U.S. Department of Energy, Nevada Operations Office.

EPA, see U.S. Environmental Protection Agency.

ERDA, see Energy Research and Development Administration.

Energy Research and Development Administration. 1977. Final Environmental Impact Statement, Nevada Test Site, Nye County, Nevada. ERDA-155. Las Vegas, NV.

LLNL, see Lawrence Livermore National Laboratory.

Lawrence Livermore National Laboratory. 1982. Energy and Technology Review: The Geology of Yucca Flats, April, UCRL-52000-82-4. Livermore, CA.

Murphy, T., Bureau of Federal Facilities. 2004. Letter to R. Bangerter (NNSA/NSO) entitled, "Review of Industrial Sites Project Document Guidance for Calculating Industrial Sites Project Remediation Goals for Radionuclides in Soil Using the Residual Radiation (RESRAD) Computer Code.” 19 November. Las Vegas, NV.

NAC, see Nevada Administrative Code.

NBMG, see Nevada Bureau of Mines and Geology.

NCRP, see National Council on Radiation Protection and Measurements.

NNSA/NSO, see U.S. Department of Energy, National Nuclear Security Administration Nevada Site Office. 
NNSA/NV, see U.S. Department of Energy, National Nuclear Security Administration Nevada Operations Office.

National Council on Radiation Protection and Measurements. 1999. Recommended Screening Limits for Contaminated Surface Soil and Review of Factors Relevant to Site-Specific Studies, NCRP Report No. 129. Bethesda, MD.

Nevada Administrative Code. 2005. NAC 459.9972, “UST Closure” Carson City, NV. As accessed at http://www.leg.state.nv.us/nac on 15 December 2006.

Nevada Administrative Code. 2006a. NAC 445A.227, “Contamination of Soil: Order by Director for Corrective Action; Factors To Be Considered in Determining Whether Corrective Action Required.” Carson City, NV. As accessed at http://www.leg.state.nv.us/nac on 15 December.

Nevada Administrative Code. 2006b. NAC 445A.22705, “Contamination of Soil: Evaluation of Site by Owner or Operator; Review of Evaluation by Division.” Carson City, NV. As accessed at http://www.leg.state.nv.us/nac on 15 December.

Nevada Administrative Code. 2006c. NAC 445A.2272, “Contamination of Soil: Establishment of Action Levels.” Carson City, NV. As accessed at http://www.leg.state.nv.us/nac on 15 December.

Nevada Bureau of Mines and Geology. 1998. Mineral and Energy Resource Assessment of the Nellis Air Force Range, Open-File Report 98-1. Reno, NV.

REECo, see Reynolds Electrical \& Engineering Co., Inc.

Reynolds Electrical \& Engineering Co., Inc. 1967. Engineering Drawing, RL-871, entitled "Nevada Test Site - Area 15 U.S. Public Health Service Farm Sprinkler System Plan and Section,” 17 June. Las Vegas, NV.

USGS, see U.S. Geological Survey.

U.S. Department of Energy. 1993. Radiation Protection of the Public and the Environment, DOE Order 5400.5, Change 2. Washington, DC: U.S. Government Printing Office.

U.S. Department of Energy, National Nuclear Security Administration Nevada Operations Office. 2002a. Industrial Sites Quality Assurance Project Plan, Nevada Test Site, Nevada, Rev. 3, DOE/NV--372. Las Vegas, NV.

U.S. Department of Energy, National Nuclear Security Administration Nevada Operations Office. 2002b. Underground Test Area Project Waste Management Plan, DOE/NV--343-Rev. 2. Las Vegas, NV. 
U.S. Department of Energy, National Nuclear Security Administration Nevada Site Office. 2004. NV/YMP Radiological Control Manual, Rev. 5, DOE/NV/11718-079. Prepared by Bechtel Nevada. Las Vegas, NV.

U.S. Department of Energy, National Nuclear Security Administration Nevada Site Office. 2006. Industrial Sites Project Establishment of Final Action Levels, Rev. 0, DOE/NV--1107. Las Vegas, NV.

U.S. Department of Energy, Nevada Operations Office. 1992. Remedial Investigation and Feasibility Study for the Plutonium Contaminated Soils at Nevada Test Site, Nellis Air Force Range and Tonopah Test Range, April. Las Vegas, NV.

U.S. Department of Energy, Nevada Operations Office. 1998. Nevada Test Site Resource Management Plan, DOE/NV-518. Las Vegas, NV.

U.S. Environmental Protection Agency. 2002. Guidance for Quality Assurance Project Plans, EPA QA/G5. Washington, DC.

U.S. Environmental Protection Agency. 2004. Region 9 Preliminary Remediation Goals (PRGs). As accessed at http://www.epa.gov/region09/waste/sfund/prg/index.htm on 1 November. Prepared by S.J. Smucker. San Francisco, CA.

U.S. Environmental Protection Agency. 2006. EPA Guidance on Systematic Planning Using the Data Quality Objectives Process, EPA QA/G-4. Washington, DC.

U.S. Geological Survey. 1995. Summary of Hydrogeologic Controls on Ground-Water Flow at the Nevada Test Site, Nye County, Nevada, WRIR 96-4109. Prepared by R.J. Laczniak, J.C. Cole, D.A. Sawyer, and D.A. Trudeau. Carson City, NV.

Winograd, I.J., and W. Thordarson. 1975. Hydrology and Hydrochemical Framework, South-Central Great Basin, Nevada-California, with Special Reference to the Nevada Test Site, USGS Professional Paper 712-C. Denver, CO. 


\section{Appendix C}

\section{Nevada Division of Environmental Protection Comments}

(2 Pages) 


\section{NEVADA ENVIRONMENTAL RESTORATION PROJECT DOCUMENT REVIEW SHEET}

\begin{tabular}{|l|l|}
\hline $\begin{array}{l}\text { 1. Document Title/Number: } \\
\text { Draft Streamlined Approach for Environmental Restoration (SAFER) } \\
\text { Plan for Corrective Action Unit 124: Storage Tanks, Nevada Test } \\
\text { Site, Nevada }\end{array}$ & Document Date: 03/08/2007 \\
\hline 3. Revision Number: 0 & 4. Originator/Organization: Stoller-Navarro \\
\hline 5. Responsible NNSA/NV ERP Project Manager: Peter A. Sanders & 6. Date Comments Due: $03 / 22 / 2007$ \\
\hline 7. Review Criteria: Full & \\
\hline 8. Reviewer/Organization/Phone No: Don Elle and Ted Zaferatos, NDEP, 486-2850 & 9. Reviewer's Signature: \\
\hline
\end{tabular}

\begin{tabular}{|c|c|c|c|c|}
\hline $\begin{array}{l}\text { 10. Comment } \\
\text { Number/Location }\end{array}$ & 11. Type* & 12. Comment & 13. Comment Response & $\begin{array}{c}14 . \\
\text { Accept }\end{array}$ \\
\hline $\begin{array}{l}\text { 1.) Section 2.2.1, } \\
\text { History and } \\
\text { Process } \\
\text { Knowledge, Page } \\
10\end{array}$ & Mandatory & $\begin{array}{l}\text { As Tungsten was used in the } 1969-1970 \text { cattle } \\
\text { experiments and as minimal information exists on these } \\
\text { experiments, consideration should be given to testing for } \\
\text { tungsten along with the other metals listed in Table } 3-2 \\
\text { (page 24). }\end{array}$ & $\begin{array}{l}\text { The text below will be added to section } 2.2 .1 \text { of the } \\
\text { SAFER: } \\
\text { Further research was conducted looking into the } \\
\text { potential environmental impact from either } \\
\text { radioactive or non-radioactive tungsten as a } \\
\text { COPC. Tungsten is a relatively non-toxic element } \\
\text { and there are no EPA Region } 9 \text { PRGs established. } \\
\text { Tungsten is not listed in } 40 \text { CFR } 261 \text { Appendix VIII } \\
\text { or the } 40 \text { CFR } 264 \text { Appendix IX list. Therefore, it is } \\
\text { not considered to be problematic by EPA from } \\
\text { either a risk or a waste standpoint. } \\
\text { The radioactive tungsten was also researched. } \\
\text { Naturally occurring tungsten consists of five } \\
\text { isotopes whose half-lives are so long that they can } \\
\text { be considered stable. Twenty-seven radioisotopes } \\
\text { of tungsten have been characterized, the most } \\
\text { stable of which are W-181 with a half-life of } 121.2 \\
\text { days, W- } 185 \text { with a half-life of } 75.1 \text { days, W- } 188 \\
\text { with a half-life of } 69.4 \text { days, and W- } 178 \text { with a half- } \\
\text { life of } 21.6 \text { days. All of the remaining radioactive } \\
\text { isotopes have half-lives of less than } 24 \text { hours, and } \\
\text { most of these have half-lives that are less than } 8 \\
\text { minutes. } \\
\text { If non-radioactive tungsten was used in the EPA }\end{array}$ & \\
\hline
\end{tabular}




\section{NEVADA ENVIRONMENTAL RESTORATION PROJECT DOCUMENT REVIEW SHEET}

\begin{tabular}{|c|c|c|c|}
\hline $\begin{array}{l}\text { 1.) Section } 2.2 .1 \\
\text { History and } \\
\text { Process } \\
\text { Knowledge, Page } \\
10\end{array}$ & Mandatory & $\begin{array}{l}\text { As Tungsten was used in the } 1969-1970 \text { cattle } \\
\text { experiments and as minimal information exists on these } \\
\text { experiments, consideration should be given to testing for } \\
\text { tungsten along with the other metals listed in Table } 3-2 \\
\text { (page 24). }\end{array}$ & $\begin{array}{l}\text { experiments then there is no known potential } \\
\text { toxicity. If radioisotopes of tungsten were used } \\
\text { they would have decayed away in the } 30 \text { plus } \\
\text { years since they were used and there would be no } \\
\text { traces remaining at the site. } \\
\text { Therefore, tungsten was not added as a COPC for } \\
\text { the EPA Farm plots. } \\
\text { References: } \\
\text { Los Alamos National Laboratory-tungsten } \\
\text { DC/AC circuits and Electronic: Principles and } \\
\text { Application by robert K. Herrick, Published by } \\
\text { Delmar Learning } 2003 \text { for Purdue University. } \\
\text { National Nuclear Data Center Table of Nuclides. } \\
\text { http://www.nndc.bnl.gov/chart/ } \\
\text { U.S. Environmental Protection Agency, } 2004 \text { (as } \\
\text { revised). Region } 9 \text { Preliminary Remediation Goals } \\
\text { (PRGs). As accessed at } \\
\text { http://www.epa.gov/region09/waste/sfund/prg/inde } \\
\text { x.html. } \\
\text { U.S. Environmental Protection Agency, } 2006 \text {. As } \\
\text { access at http://www.epa.gov/radiation/mixed- } \\
\text { waste. } \\
\text { U.S. Environmental Protection Agency, } 2007 . \text { As } \\
\text { accessed at http://www.haspub.epa.gov/srs/. }\end{array}$ \\
\hline $\begin{array}{l}\text { 2.) Section } 3.2 .4 \\
\text { Design } \\
\text { Description/Option, } \\
\text { Page } 33\end{array}$ & Mandatory & $\begin{array}{l}\text { Reference to Section B.4.2.1.2 should be to Section } \\
\text { B.4.2.1. }\end{array}$ & $\begin{array}{l}\text { Reference to Section B.4.2.1.2 has been changed } \\
\text { to read Section B.4.2.1. }\end{array}$ \\
\hline $\begin{array}{l}\text { 3.) Section } 6.2 .4 \text {, } \\
\text { Mixed Low-Level } \\
\text { Waste, Page } 50\end{array}$ & Mandatory & $\begin{array}{l}\text { Note that the NDEP Permit Number for a Hazardous } \\
\text { Waste Management Facility, as issued in 2005, is NEV } \\
\text { HW0021. }\end{array}$ & $\begin{array}{l}\text { The NDEP Permit Number for a Hazardous Waste } \\
\text { Management Facility, as issued in } 2005 \text {, has been } \\
\text { changed to NEV HW0021. The reference for the } \\
\text { Permit has been changed to reflect the } 2005 \\
\text { issuance. }\end{array}$ \\
\hline
\end{tabular}




\title{
Library Distribution List
}

\author{
$\underline{\text { Copies }}$ \\ U.S. Department of Energy \\ 1 (Uncontrolled, electronic copy) \\ National Nuclear Security Administration \\ Nevada Site Office \\ Technical Library \\ P.O. Box 98518, M/S 505 \\ Las Vegas, NV 89193-8518 \\ U.S. Department of Energy \\ Office of Scientific and Technical Information \\ 1 (Uncontrolled, electronic copy) \\ P.O. Box 62 \\ Oak Ridge, TN 37831-0062 \\ Southern Nevada Public Reading Facility \\ 2 (Uncontrolled, electronic copy) \\ c/o Nuclear Testing Archive \\ P.O. Box 98521, M/S 400 \\ Las Vegas, NV 89193-8521 \\ Manager, Northern Nevada FFACO \\ 1 (Uncontrolled, electronic copy) \\ Public Reading Facility \\ c/o Nevada State Library \& Archives \\ Carson City, NV 89701-4285
}

